\title{
Deschmann's pile-dwelling sites near Ig and the cultural-chronological attribution of the Late Copper Age Ljubljana culture
}

\author{
Kulturna in časovna umestitev \\ poznobakrenodobne ljubljanske kulture \\ na Dežmanovih koliščih pri Igu
}

\author{
Elena LEGHISSA
}

\begin{abstract}
Izvleček
V članku so predstavljeni rezultati obširne raziskave poznobakrenodobnih najdb Dežmanovih kolišč pri Igu na Ljubljanskem barju. Podana sta pregled raziskav in problematika opredelitve te kulture. Na podlagi revizije keramičnega gradiva in arhivov ter nove tipološko-kronološke analize najdb z Dežmanovih kolišč so predstavljeni posodobljeni kulturološka in kronološka opredelitev ljubljanske kulture ter njen značilni repertoar keramičnih najdb. Poleg značilnih posod, praviloma okrašenih z vtiskovanjem na ploščat predmet navite niti, je v okvir na novo opredeljene ljubljanske kulture uvrščena tudi t. i. spremna lončenina, ki kaže na vplive predvsem kulture Somogyvár-Vinkovci z območja Karpatske kotline. V nekaterih posodah ljubljanske kulture odsevajo tradicija vučedolske kulture ter vplivi in morda s stiki s kulturami vrvičaste keramike, kroglastih amfor in zvončastih čaš.
\end{abstract}

Ključne besede: Slovenija; Ljubljansko barje; Ig; Dežmanova kolišča; tretje tisočletje pr. Kr.; ljubljanska kultura; keramika; okras

\begin{abstract}
The contribution presents the results of a comprehensive study of the Late Copper Age Deschmann's pile-dwelling sites near Ig in the Ljubljansko barje, central Slovenia. It opens with a history of research and goes on to tackle the main topics associated with the cultural attribution of the sites. A re-examination of the recovered pottery and available archival records, coupled with a new typological and chronological analysis of the small finds has enabled a cultural and chronological redefinition of the Ljubljana culture and its characteristic pottery. In addition to the typical vessel forms, usually decorated with whipped-cord impressions, the newly-defined Ljubljana culture includes common ware that reveals influences primarily from the Somogyvár-Vinkovci culture in the Carpathian Basin. Some of the vessels of the Ljubljana culture also follow the tradition of the Vučedol culture, while others reflect the influences and maybe contacts with the Corded Ware, Globular Amphora and Bell Beaker cultures.
\end{abstract}

Keywords: Slovenija; Ljubljansko barje; Ig; Deschmann's pile-dwelling sites; $3^{\text {rd }}$ millennium BC; Ljubljana culture; pottery; decoration 


\section{HISTORY OF RESEARCH INTO THE LJUBLJANA CULTURE}

It was Oswald Menghin who first introduced the term Ljubljana culture (Laibachkultur in German) in the 1930s. ${ }^{1}$ The term referred to all the finds recovered from the pile-dwelling sites in the Ljubljansko barje (Ljubljana Marshes) up to that time, which were seen as mirroring influences of the Baden culture in the early phase and those of the Corded Ware culture in the late phase. ${ }^{2}$ Kurt Willvonseder ${ }^{3}$ and Rajko Ložar ${ }^{4}$ adopted the term in the 1940s to define the finds from the pile-dwelling sites around Ig, which Karl Deschmann (Dragotin Dežman) investigated in the 1870 s and are today known in literature as Deschmann's pile-dwelling sites (Dežmanova kolišča pri Igu) (Fig. 1).

Among the first analyses of the finds from Deschmann's sites is Ložar's study on the Ljubljana pottery, published in 1941 in Glasnik muzejskega društva za Slovenijo. ${ }^{5}$ In it, Ložar emphasised the similarities of the finds from Ig with the array of finds attributed to the Globular Amphora culture, which he saw as an important contributing factor to the formation of the Ljubljana culture. ${ }^{6}$ In the 1950s, Paola Korošec wrote an extensive discussion on the finds from Deschmann's piledwelling sites and their cultural attribution. ${ }^{7}$ Using the typological features of its pottery, she distinguished between two groups representing two chronological phases. According to her division, the early group called Ig I was characterised by vessel forms such as amphorae, jugs, footed bowls and others, mainly decorated with incisions and stab-and-drag (Furchenstich) technique; she correlated this group with the Baden-Pécel culture. ${ }^{8}$ The other, later group called Ig II included bowls, vessels with round, hollow foot and hemispherical bowls with a thickened rim primarily decorated with 'whipped-cord impressions' and stabs, ${ }^{9}$ which she correlated with the late phase of the Bell Beaker culture in Austria (the Ragelsdorf-Oggau-Loretto type) and the early phase of the Unětice culture;

\footnotetext{
1 Menghin 1931.

2 Menghin 1925, 763; id. 1931, 54.

3 Willvonseder 1940, 30.

${ }^{4}$ Ložar 1941.

5 Ib.

${ }^{6}$ Ib., 21-27, 34.

7 Korošec 1958-1959.

8 Ib., 102, 104.

9 Ib., 96, 97.
}

she dated this group to the Early Bronze Age. ${ }^{10}$ Later, she also tied the Ig II group with the finds from the (cave) sites in central Dalmatia and the northern Adriatic. ${ }^{11}$

Similarly as Korošec but in the 1960s, Stojan Dimitrijević also divided the finds from Ig into two chronological phases. ${ }^{12}$ He defined the early phase (Ljubljansko barje I) as part of the Vučedol culture and the late phase (Ljubljansko barje II) as the Ljubljana facies of the Litzen culture using the term the Ljubljana culture, though not in the same sense as defined by Menghin, rather interpreting it as the result of merging elements of the Vučedol, Bell Beaker and Litzen cultures. ${ }^{13}$ The arrival of the Vučedol culture to the Ljubljansko barje area (he later renamed Ljubljansko barje I to Phase C of the Late Vučedol culture ${ }^{14}$ ) was followed by influences coming from the Bell Beaker culture that contributed to the creation of the Ljubljana culture. This was believed to have been initially contemporary with the Vučedol culture, but later became the dominant force and spread all to central Dalmatia including the island of Hvar. ${ }^{15} \mathrm{He}$ correlated it in chronological terms with the Vinkovci culture identified on the basis of the excavations at the Tržnica-Hotel site in Vinkovci. ${ }^{16}$

Within the Ljubljana culture, Dimitrijević distinguished between two regional types: Alpine and Adriatic. ${ }^{17}$ In addition to Deschmann's piledwelling sites in the Ljubljansko barje, the Alpine type included Linz-Scharlinz in Upper Austria, ${ }^{18}$ Vinomer near Metlika and Hrustovača near Sanski Most, ${ }^{19}$ all of which yielded pottery characterised by toothed rouletting that was also typical of the Bell Beaker culture, while incisions, furrowed incisions and impressions were less common. ${ }^{20}$ The sites he attributed to the Adriatic type were located along the coast from Trieste to Montenegro.

10 Ib., 99 ff, 102, 104; also see Korošec 1960-1961.

11 Korošec 1962, 214 ff, 231; she retained the division into Ig I and Ig II without substantial changes in later publications (see e.g. Korošec, Korošec 1969; Korošec 1973).

12 Dimitrijević 1961.

13 Ib., 60, 61.

14 Dimitrijević 1966.

15 Dimitrijević 1961, 63.

16 Dimitrijević 1966, 34.

17 Dimitrijević 1967.

18 The find attributed to the Ljubljana culture is actually closer to those of the Corded Ware culture (see Pittioni 1954, Fig. 167: 54).

19 Dimitrijević 1967, 8 ff.

${ }^{20} \mathrm{Ib}$., 10; for the toothed rouletting, see Leghissa 2015. 


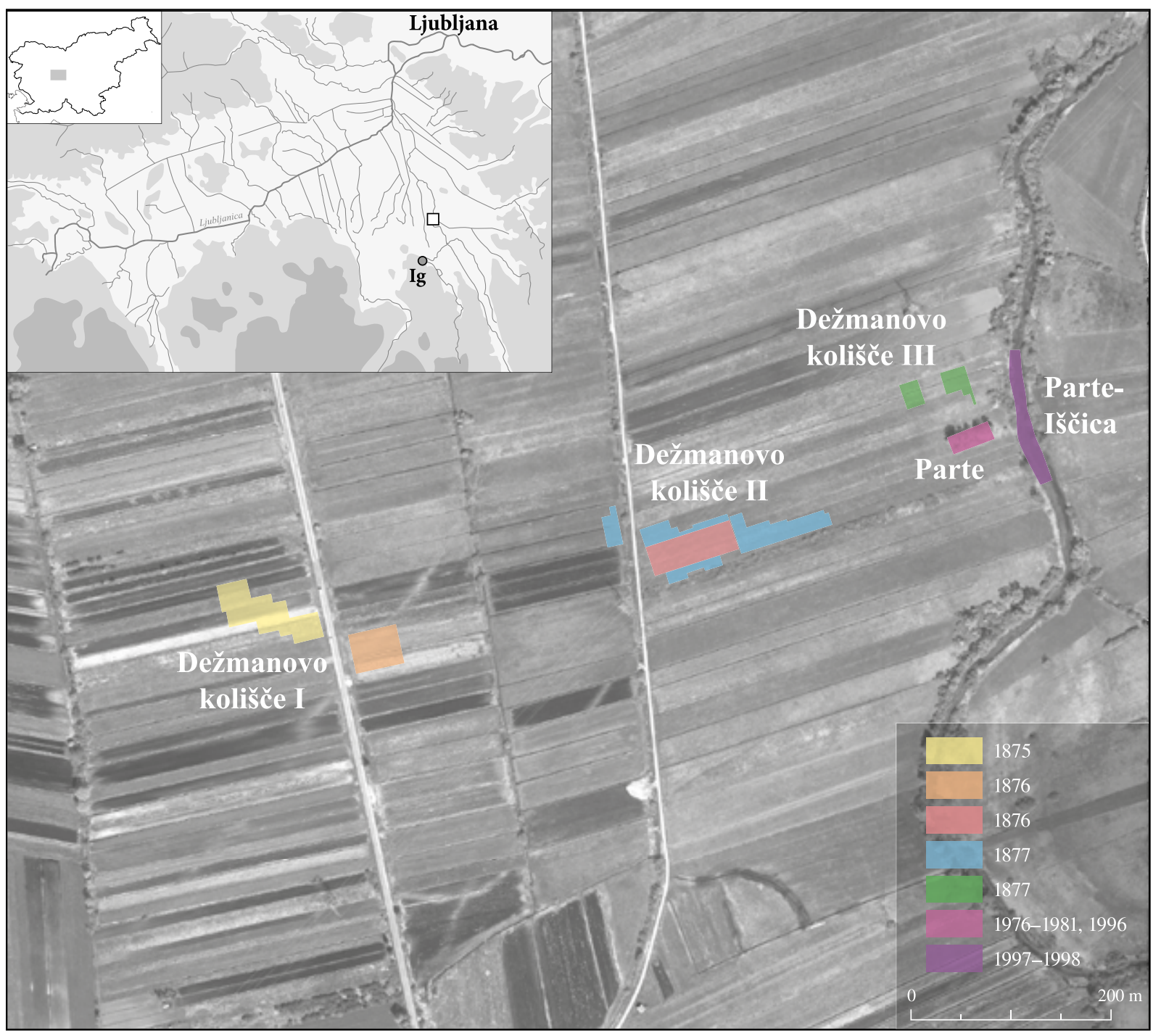

Fig. 1. Pile-dwelling settlements northeast of Ig (adapted from Leghissa 2017, Fig. 31).

Sl. 1. Koliščarska poselitev severo-vzhodno od Iga (posodobljeno po Leghissa 2017, sl. 31).

Among its characteristic features he mentioned 'globular vessels with subcutaneous lugs'. Similarly as the Vinkovci culture, he marked the Ljubljana culture as a post-Vučedol cultural phenomenon of the Early Bronze Age with roots in the Vučedol and Bell Beaker cultures. ${ }^{21}$

In the publication of the 1977-1978 excavation in Vinkovci, Dimitrijević divided the Vinkovci culture into three phases of development. In this division, the late classic phase of the Vučedol culture was followed by the Vinkovci A1 phase that was contemporaneous with the Late Vučedol phase (Phase $\mathrm{C}$ of the Vučedol culture), ${ }^{22}$ in turn followed by the late phase of the Vinkovci culture

\footnotetext{
21 Ib., 10-11.

22 Dimitrijević 1982, 15-16.
}

(Vinkovci A2) correlated with the Ljubljana culture on the basis of a pottery sherd from Vinkovci that is similar to those from Deschmann's pile-dwelling sites, the latter attributed to the Alpine type of the Ljubljana culture. $^{23}$

Another author who proposed a chronological framework including the pile-dwelling sites in the Ljubljansko barje is Hermann Parzinger, who divided the finds from the pile-dwelling sites near Ig into three successive chronological phases (Ig $\mathrm{a}, \mathrm{b}$ and $\mathrm{c}) \cdot{ }^{24} \mathrm{He}$ correlated the finds of the Ig a phase mainly with the ceramic finds characteristic of the Makó-Jevišovice-Vučedol cultures. He at-

23 Ib., 18, 20.

${ }^{24}$ Parzinger 1984. He attributed the Ig $\mathrm{c}$ phase to the time of the Early Bronze Age Litzen culture. 
tributed the Ig $\mathrm{b}$ phase (Ljubljana culture) to the early part of the Early Bronze Age and correlated it with the Vinkovci, Kosihy-Čaka, Hatvan, Nagyrév, Kisapostag and Nitra cultures. ${ }^{25} \mathrm{He}$ also studied the decorative techniques, the furrowed incisions and 'whipped cord impressions' in particular, which Paola and Josip Korošec saw as one of the main elements for distinguishing between their Ig I and Ig II groups (furrowed incisions characteristic of Ig I and whipped cord impressions of Ig II). The key observation for Parzinger was that the 'whipped cord impressions' imitated the motifs typical of the decoration with furrowed incisions, which led him to posit a continuous development in the Ljubljansko barje from the Vučedol to the Ljubljana culture. ${ }^{26} \mathrm{He}$ believed that the interpretation of two groups was unfounded and that it was only reasonable to talk of chronological phases that succeed each other in time, but shared the same origin. ${ }^{27}$

In the 1980s, Blagoje Govedarica published a study on the Early Bronze Age in the Adriatic littoral that also tackled the Ljubljana culture. ${ }^{28}$ In his opinion, close ties between the Ljubljansko barje and the Trieste Karst already existed in the early phase of the pile-dwelling sites near Ig (Ig I after P. Korošec), which became more prominent in Ig II. He renamed Dimitrijević' Alpine type of the Ljubljana culture to the classic Ljubljana culture, the Adriatic type to the central Adriatic type. ${ }^{29}$ The former also included the finds from the caves in the Trieste area and several sites in littoral Istria (such as Vaganačka pećina) and north-western Bosnia. ${ }^{30}$ By analysing the stratigraphic evidence from the sites in the Trieste Karst (such as Grotta del Mitreo/Mitrejeva jama, Grotta degli Zingari/ Ciganska jama and Grotta Tartaruga/Želvina jama near Briščiki), he distinguished between the early and late phases of the classic Ljubljana culture. He dated the classic Ljubljana culture to a time after the Vučedol culture and before the onset of the Early Bronze Age (BA A after Reinecke).$^{31}$ The similarities in the form and decoration of the pottery enabled him to correlate the central Adriatic type of the Ljubljana culture with the early phase of the classic

${ }^{25}$ Parzinger 1984, 40, 42 ff.

26 Ib., $45 \mathrm{ff}$.

27 Ib., 49 ff.

28 Govedarica 1989; some of the main points of this study are given in Govedarica 1988-1989.

${ }^{29}$ Govedarica 1988-1989, 403; Govedarica 1989, 25 ff, 94 ff.

30 Govedarica 1989, 28-31.

${ }^{31} \mathrm{Ib} ., 62$.
Ljubljana culture. ${ }^{32}$ Similarly as Dimitrijević, ${ }^{33}$ he attributed the sites in the southern Adriatic, such as the tumuli at Rubež and Mala Gruda, as well as the Odmut cave, to the late phase. ${ }^{34}$ His division of the Ljubljana culture is problematic, however, in that it is based on the stratigraphy of the cave sites in the Trieste area, where excavators had great difficulties in distinguishing between different layers; the same spits actually revealed both finds showing influences of the Vučedol culture and those attributed to either Ljubljana, Cetina and the Bronze Age Castellieri cultures. ${ }^{35}$

A more recent take on the $3^{\text {rd }}$ millennium $B C$ comes from Margarita Primas, in the publication of the Velika Gruda tumulus and a revised analysis of the finds from the Mala Gruda tumulus in Montenegro, ${ }^{36}$ but also from Joseph Maran, who published a study on the cultural changes that took place in Greece and the Cyclades in the late $3^{\text {rd }}$ millennium BC. ${ }^{37}$ Primas used the radiocarbon dates for the tumuli, including one with a range of 3081-2886 cal BC $(1 \sigma),{ }^{38}$ to correlate the Montenegro sites with the Early Vučedol phase after Dimitrijević rather than with the Late Vučedol horizon in the Danube Basin and the south-eastern Alpine area. ${ }^{39}$ She found parallels for the finds from Velika Gruda and Mala Gruda in the Near East or eastern Mediterranean, as well as the Balkan and Apennine Peninsulas. ${ }^{40}$ In the chronological framework that Maran proposed, the Late Vučedol phase ( $C$ after Dimitrijević) was contemporaneous with the Makó-Kosihy-Čaka cultures and the early phase of the Somogyvár-Vinkovci culture. The last one lasted into the 'post-Vučedol' time together with the Csepel group of the Bell Beaker

32 Ib., 39, $94 \mathrm{ff}, 102 \mathrm{ff}$

33 E.g. Dimitrijević 1979, 321.

34 Govedarica 1989, 178, 188.

35 See e.g. Stacul 1971-1972; Stacul 1976; Gilli, Montagnari Kokelj 1993; Gilli, Montagnari Kokelj 1994; Gilli, Montagnari Kokelj 1996; Montagnari Kokelj, Crismani 1997; Montagnari Kokelj, Greif, Presello 2002; I was able to examine the finds from the caves in the Trieste area in the Soprintendenza Archeologia del Friuli Venezia Giulia in Trieste. With regards to these, Manuela Montagnari Kokelj and her colleagues (see e.g. Gilli, Montagnari Kokelj 1994, 158; also see Forenbaher 2018a, 124) have also drawn attention to the problems concerning the division proposed by Govedarica.

36 Primas 1996.

37 Maran 1998.

38 Primas 1996, 48 ff, Tab. 4.2.

39 Ib., 165.

${ }^{40}$ Ib., 141-162. 
culture (Glockenbecher-Csepel Kultur in German), the Nagyrév and the Ljubljana culture. ${ }^{41}$ Similarly as Primas, Maran also did not attribute the tumuli of Mala Gruda, Velika Gruda and Boljevića Gruda near Podgorica to a time of the Late Vučedol culture and did not correlate them with the Ljubljana culture, but rather with the 'Montenegrin variety of the Vučedol culture. ${ }^{42}$

In the last two decades, the interdisciplinary investigations that Anton Velušček and his colleagues conducted in the Ljubljansko barje have brought significant advances to a more precise dating of the pile-dwelling settlements in the area. ${ }^{43}$ In the publication of the Založnica site near Kamnik pod Krimom, Velušček and Katarina Čufar attribute the ceramic finds to the Somogyvár-Vinkovci culture, ${ }^{44}$ together with most of the pile-dwelling sites existing in the Ljubljansko barje in the $3^{\text {rd }}$ millennium BC (Parte, Dušanovo $=$ Črni graben ${ }^{45}$ and also part of the finds from Deschmann's piledwelling sites $\left.{ }^{46}\right)$. Dendrochronological analyses place the pile-dwelling sites of the SomogyvárVinkovci culture to the $25^{\text {th }}$ century BC, with their beginnings reaching back to the $26^{\text {th }}$ century BC. ${ }^{47}$ With such cultural attribution of Založnica and other $3^{\text {rd }}$-millennium sites in the Ljubljansko barje, Velušček and his colleagues raise the question of whether it is reasonable to posit the existence of a Late Vučedol phase in the Ljubljansko barje that would be, according to Dimitrijević, contemporary with the Early Somogyvár-Vinkovci culture. At the same time, he opens the question concerning the relationship between the Somogyvár-Vinkovci and Ljubljana cultures, proposing that the latter be earlier than the former. ${ }^{48}$

41 Maran 1998, 314-315, 350, Pl. 82.

42 Ib., Fn. 243; Maran 2007, 8 ff, Fn. 36.

43 Velušček, Čufar, Levanič 2000; Velušček, Čufar 2002; Velušček, Čufar 2003; Velušček et al. 2004; Velušček, Toškan, Čufar 2011 and others.

44 Velušček, Čufar 2003.

${ }^{45}$ Names of the pile-dwelling site after Velušček 2019, 73.

46 Velušček 2014; Velušček, Čufar 2014; similarly as I. Bóna observed in the 1960s (Bóna 1963; 1965).

47 See e.g. Velušček 2014, 638-641; Velušček, Čufar 2014, Tab. 2.

48 The asynchronous ZAL-FRSP2 dendrochronological curve suggests an early dating of the Ljubljana culture in relation to the Somogyvár-Vinkovci culture (Velušček, Čufar 2003, 128, 131-132; Velušček 2014, 240-241). The said curve remains asynchronous and hence unreliable as a foundation for arguing in favour of an earlier dating and the possibility of an earlier phase of the settlement.
Among the most recent studies of the Ljubljana culture is that by Stašo Forenbaher, ${ }^{49}$ who distances himself from the traditional nomenclature and attributions of archaeological cultures and periods. Rather, he focuses on the 'pottery styles' to define the Ljubljana and Cetina cultures. The $3^{\text {rd }}$ millennium $\mathrm{BC}$ is thus viewed in terms of pottery styles and their chronological dimension..$^{50} \mathrm{He}$ considers the Alpine and the Adriatic types according to Dimitrijević as a common Ljubljana-Adriatic style, which also includes the finds from the late phase of Deschmann's pile-dwelling sites and the related pottery from the Ljubljansko barje, the Slovenian and Trieste Karst, two sites in northern Italy and the eastern Adriatic coast all to the tumuli in Montenegro and Albania. ${ }^{51} \mathrm{He}$ uses stratigraphy, metal artefacts and radiocarbon dates to attribute the Ljubljana-Adriatic style to the first half of the $3^{\text {rd }}$ millennium BC. Considering the dates for the Montenegrin tumuli, the Ljubljana-Adriatic style is contemporary with the Vučedol style, not only the Late, but also the Classic. In the mid- $3^{\text {rd }}$ millennium $\mathrm{BC}$, the Cetina sytle is believed to have replaced the Ljubljana-Adriatic style. ${ }^{52}$ Forenbaher's reticence towards cultural attributions is understandable if perceiving an archaeological culture in the classic, Child sense, i.e. as an entity of a uniform material culture, burial ritual, settlement pattern, time and space. In this sense, the Ljubljana culture is a specific phenomenon mainly characterised by cave sites across the Adriatic area even though the name stems from the pile-dwelling sites in the Ljubljansko barje that stand out in both type of settlement and peripheral location. In spite of this, this contribution also uses the term Ljubljana culture with the aim of emphasising the uniformity of the material culture in these areas. ${ }^{53}$

${ }^{49}$ Forenbaher 2018a; also see 2018b.

50 Forenbaher 2018a, 114-115.

51 Ib., 117, 122, Fig. 4; Forenbaher also considers as part of the Ljubljana culture finds that in my opinion rather reflect the influences of the Vučedol culture, e.g. bowls on a cross- or star-shaped foot from the Trieste Karst, which show elements of the Vučedol culture, most likely from the Carpathian Basin (for details, see Leghissa et al. 2020), also finds from the tumuli in Montenegro.

${ }^{52}$ Forenbaher 2018a, 152-153, also see 2018b, 140-141.

${ }^{53}$ Given the wide spatial distribution of the Ljubljana culture and the apparent differences between individual areas, it is reasonable to wonder whether the term Ljubljana culture can at all be retained for the whole area. It should be noted that the differences, which may reflect different 'cultural' identities, are often associated with the research methods, range and dissemination. 


\section{DESCHMANN'S PILE-DWELLING SITES AND THE CORRELATION OF THE RECOVERED POTTERY WITH INDIVIDUAL EXCAVATION CAMPAIGNS}

The pottery from Deschmann's pile-dwelling sites constitutes the largest and most representative ceramic assemblage of the Ljubljana culture, hence its revision offers a new insight into the material remains as a whole and their chronological and cultural place within the $3^{\text {rd }}$ millennium $\mathrm{BC}$. The author has performed the revision as part of the dissertation that led to a redefinition of the Ljubljana culture. This contribution briefly presents her findings (Leghissa 2017). ${ }^{54}$

Deschmann's pile-dwelling sites near Ig were discovered and investigated in three excavation campaigns taking place between 1875 and 1877 . The fieldwork was headed by Dragotin Dežman (Karel Deschmann in German), then curator at the Provincial Museum of Carniola (Krainisches Landes-Museum) in Ljubljana. Three pile-dwelling settlements came to light at the Kepje and Parte sites that are today known as Deschmann's Piledwelling Sites I, II and III (Fig. 1). The discovery and the recovered finds attracted the attention of both professional and general public. The artefacts were exhibited in the Provincial Museum in Ljubljana, though a considerable number of them also went to other museums and institutions in Austro-Hungary and elsewhere across Europe. ${ }^{55}$ This dispersed state prevents a complete list of finds from Deschmann's pile-dwelling sites to be created.

The Provincial Museum began inventorying the small finds towards the end of the $19^{\text {th }}$ century under Alfons Müllner, the new museum curator. He focused on the typological features of objects, so much so that he neither stored nor documented the artefacts according to their archaeological context. In the case of the pile-dwelling sites from the Ig area, he joined the finds according to

\footnotetext{
54 A monograph on the complete assemblage accompanied by in-depth discussions is in preparation to be published in the Katalogi in Monografije series of the Narodni muzej Slovenije (NMS).

${ }^{55}$ Several finds are kept in the Naturhistorisches $\mathrm{Mu}$ seum in Vienna; other institutions that hold or received finds from Deschmann's excavations in $1875-1877$ as a gift include the Museum der Sternwarte Kremsmünster in Upper Austria, the M. Much Collection in Vienna, the Universalmuseum Joanneum in Graz/Gradec, Austria, the Anthropologische Gesellschaft in Köln and the Museo di antropologia dell'Università di Padova.
}

individual campaigns and thus losing the data on their original findspot and context. It is believed, however, that it was Deschmann who first began joining finds according to type ${ }^{56}$ This led to a loss of important data on which finds came to light during which campaigns and in which settlement.

One of the aims of the revision was to establish when the finds came to light and at which piledwelling site. By studying Deschmann's reports and notes, newspaper articles, the report by Eduard von Sacken, ${ }^{57}$ as well as the years and other markings that Deschmann wrote on some of the vessels found in 1877 in the area of Deschmann's Pile-dwelling Site II, it was possible to correlate a fair number of the vessels with the associated pile-dwelling site. ${ }^{58}$

The finds that can be ascribed to Deschmann's Pile-dwelling Site I are mostly those interpreted as forming part of the Vučedol culture; these include richly decorated biconical and globular jugs, globular two-handled vessels and their fragments decorated with circular motifs, as well as crossfooted bowls with interior and exterior decoration. Site I can be interpreted as a Vučedol settlement, which radiocarbon evidence dates from at least the late $27^{\text {th }}$ and into the $26^{\text {th }}$ century BC. ${ }^{59}$ The finds of this phase have been attributed to the Ljubljansko barje variant of the Vučedol culture. ${ }^{60}$

Deschmann's writings reveal Site II to be different from Site I in that the piles were located closer together and were thicker. He called it Hauptpfahlbau (main pile-dwelling site). The decoration on the ceramic vessels and their fragments was executed with greater precision, mostly with 'cord impressions' (schnurförmigen Eindrücke in German). ${ }^{61}$ The novelty on the pottery of this site is subcutaneous lugs. ${ }^{62}$ The finds that most stand out are figural vessels, ceramic moulds for shafthole and flat axes, ceramic crucibles and copper objects. In addition to the impressed decoration using cords whipped around flat objects, vessels also bear fingertip and fingernail impressions, brushing and combing, some jar fragments have a thickened and decorated rim. Several decorated

56 Gabrovec 1971, 40; Stare 1992, 35.

57 See e.g. Deschmann 1875a-c; 1876a-d; 1878; 1888; also see von Sacken 1876; Kos 1978 and Smole 1983.

58 For more details, see Leghissa 2017, 58-79.

59 Leghissa 2018, 46.

${ }^{60}$ Leghissa 2017, 275, 278-280.

61 The decoration is made by impressing cords whipped around flat objects (Leghissa 2015).

${ }^{62}$ Deschmann 1876d, 478; Kos 1978, 55-56. 
sherds of footed bowls can also be ascribed to this site. Deschmann's Pile-dwelling Site II was most likely already established in the time of the Ljubljansko barje variant of the Vučedol culture. What remains unanswered is whether it was inhabited at the same time as Site I. Life at Site II continued and flourished in the 'late phase' of Deschmann's pile-dwelling sites identified as the Ljubljana culture.

It was much more challenging to identify the finds associated with Deschmann's Pile-dwelling Site III, which had only been excavated for a few days in the penultimate week of excavations in 1877. Deschmann reported that he unearthed few vessels, which were coarser and had thicker walls. ${ }^{63}$ Site III should be considered together with the Parte and Parte-Iščica pile-dwelling sites (Fig. 1) located in its immediate proximity. ${ }^{64}$ The Parte site, investigated in 1976-1981, is located on lots Nos. 1424-1426, some $60 \mathrm{~m}$ south of Deschmann's Site III. ${ }^{65}$ The Parte-Iščica site, excavated in 1997-1998, lies in the bed of the Iščica stream along the edge of lots Nos. 1421-1431 some 85 m east of Deschmann's Site III. ${ }^{66}$ All three locations cover a roughly 1.5 ha large area where dendrochronological analyses have revealed the existence of at least two settlements: an earlier one in the east, located under the current bed of the Iščica and dated to the $28^{\text {th }}$ and $27^{\text {th }}$ centuries BC, and a later one in the west, in the area of Harej's excavations and inhabited, presumably after a short pause, in the late $26^{\text {th }}$ and the $25^{\text {th }}$ century BC. ${ }^{67}$ The two trial trenches in 1877 most likely unearthed the northernmost edge of the west settlement, i.e. the Parte pile-dwelling site.

\section{THE FINDS OF THE LATE PHASE OF DESCHMANN'S PILE-DWELLING SITES AND THE ATTRIBUTION OF THE LJUBLJANA CULTURE}

The revision of the pottery from Deschmann's pile-dwelling sites near Ig, the correlation of the finds with individual excavation campaigns and the results of the new typo-chronological analysis ${ }^{68}$

\footnotetext{
63 Smole 1983, 155-156.

64 Also see Veluček, Čufar, Levanič 2000, 83.

65 Harej 1978; 1981-1982; 1987.

66 Veluček, Čufar, Levanič 2000.

67 Veluček, Čufar, Levanič 2000, 99.

68 The typology, as well as the chronological and cultural attribution is hereinafter taken from Leghissa 2017.
}

has revealed three main groups of finds. The first group reflects the characteristics of the Vučedol culture and also influences/contacts with contemporary cultures such as the Corded Ware, Jevišovice and the early phase of the Makó-Kosihy-Čaka cultures. ${ }^{69}$ This group is ascribed to the earliest phase of habitation at Deschmann's pile-dwelling sites (Phase I).

The second group consists of finds that a number of authors ${ }^{70}$ already attributed to the late habitation phase at Deschmann's pile-dwelling sites, i.e. to the Ljubljana culture after Dimitrijevic ${ }^{71}$ (Fig. 2: 1-19). The main characteristic is the decoration applied by impressing a cord whipped onto a flat object. The third group comprises the finds that mainly show the influences of the Somogyvár-Vinkovci and Makó-Kosihy-Čaka cultures present in the Carpathian Basin (Fig. 2: 20-23,25-31). ${ }^{72}$ Most of the finds of the second and third groups could be ascribed to Deschmann's Site II. These two groups mark the late phase of Deschmann's pile-dwelling sites.

The most characteristic vessels of the late phase at Deschmann's pile-dwelling sites according to the typology proposed by Leghissa (2017) are as follows:

- large and small globular jugs with a funnel-shaped neck of Type V4 (Fig. 2: 1,2,5);

- globular two-handled vessels with a funnel-shaped or cylindrical neck and a pair of subcutaneous lugs of Type DvP4b (Fig. 2: 3,4,9);

- gourd-like vessels with a flat globular body, some with a funnel-shaped neck (Type B1) and possibly with subcutaneous lugs or vertically perforated grips (Type B2) (Fig. 2: 7,8);

- high globular bowls with a funnel-shaped neck of Type Vs2 (Fig. 2: 14);

- high bowls with a high concave neck of Type Vs3 that may bear a pair of subcutaneous lugs (Fig. 2: 12); - hemispherical bowls with a flat thickened rim of Type S1 (Fig. 2: 16);

- bowls with hollow conical foot of Type SnN9 (Fig. 2: 18,19);

- globular cups with a funnel-shaped neck of Type Sk5 (Fig. 2: 15);

69 For a more detailed interpretation, see Leghissa 2017, 278-280.

70 See Korošec 1958-1959; Dimitrijević 1967; Dimitrijević 1979; Parzinger 1984; Govedarica 1989.

71 Dimitrijević 1967; 1979.

72 See e.g. Bondár 1995; Velušček, Čufar 2003; Kulcsár 2009. 


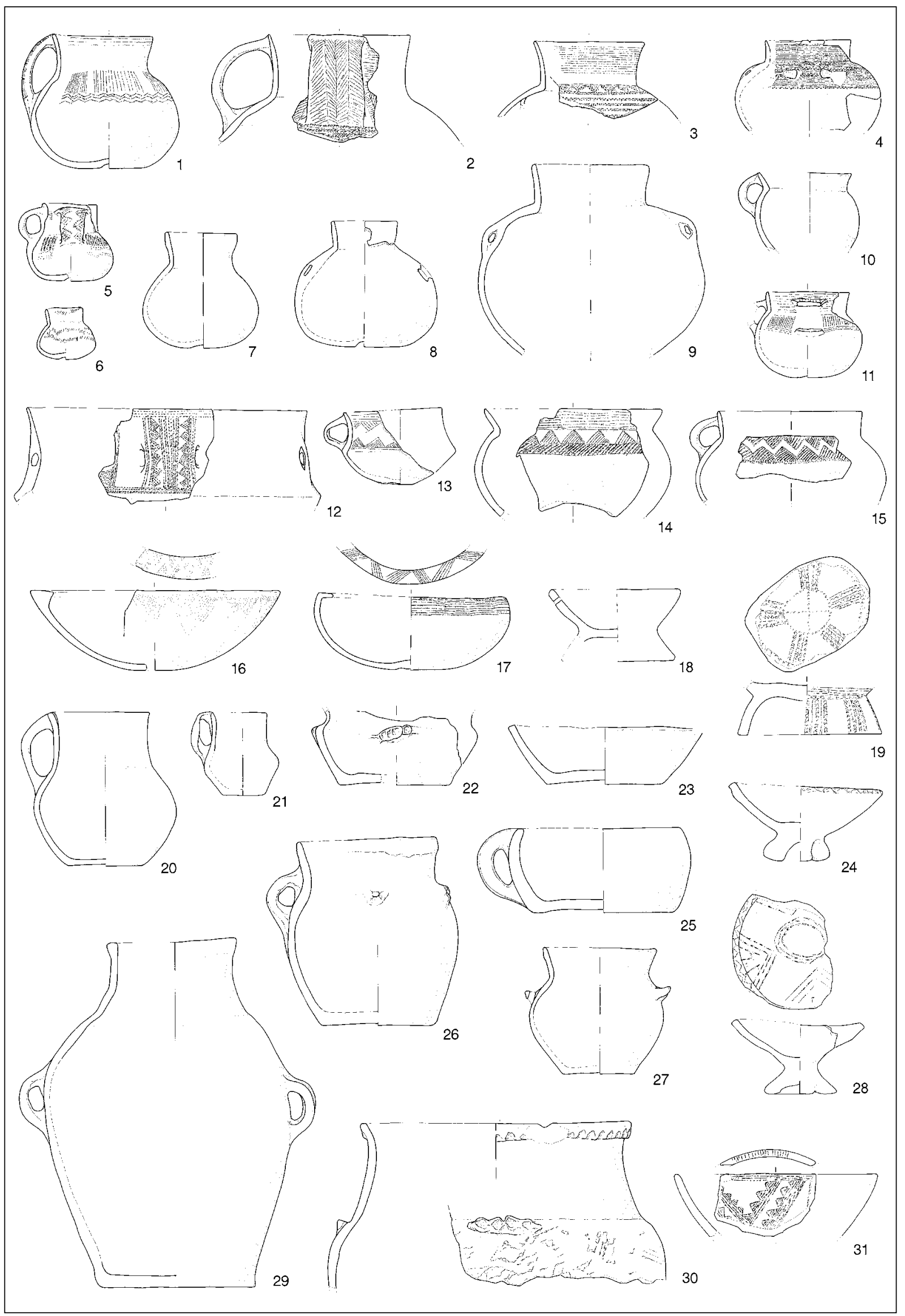


- cups with a concave neck and a sharp junction with a hemispherical lower body of Type Sk6 (Fig. 2: 13).

Other pottery forms of the second group comprise: - large and small, biconical and globular undecorated jugs of Types V1a, V2a and V2c (Fig. 2: 20,21); - globular and biconical two-handled undecorated vessels of Types DvP1 and DvP2;

- bellied two-handled vessels of a medium/coarse-grained fabric; ${ }^{73}$

- single-handled jars decorated with studs on the shoulder of Type L2 (Fig. 2: 26); $7^{74}$

- single-handled oval jars with a cylindrical neck of Type L3;

- globular or oval jars with a funnel-shaped neck of Type L5 (Fig. 2: 27);

- oval two-handled storage vessels of Type Sp1

(Fig. 2: 29);

- vessels with a thickened lip decorated with finger and/or nail impressions of Type Sp2 (Fig. 2: 30);

- mostly undecorated high bowls of Types Vsla and Vs1b (Fig. 2: 22);

- conical bowls of Type S2 (Fig. 2: 23);

- hemispherical cups of Type Sk1 (Fig. 2: 25);

- conical cups of Type Sk2;

- globular and flat globular cups of Type Sk3;

- biconical cups with a funnel-shaped neck of Type Sk4.

Some pottery types of the second or late group are only slightly altered old types, already present in the first group, i.e. the early phase at Deschmann's pile-dwelling sites. Such are the jugs with a biconical or globular body of Types V1a and V2a, twohandled vessels with a globular body of Type DvP1, undecorated jars with an oval body and a curved neck of Type L2 and high bowls with an everted rim and a flattened body of Type Vs1. They also include bowls with a cross-shaped or round foot decorated with simple motifs only on the interior and rim, which are interpreted as vestiges of the Vučedol culture (e.g. Fig. 2: 24,28,31).

${ }^{73}$ Leghissa 2017, Pl. 41: 1-3 (Korošec, Korošec 1969, Pl. 7: 2; 12: 1; uninventoried find, kept in the NMS).

${ }^{74}$ Leghissa 2017, e.g. Pl. 58: 3; 59: 1-5; 60: 3 (Korošec, Korošec 1969, Pl. 12: 6; 16: 4; 21: 2; 26: 5; 27: 1,3; 62:9).
The key novelty of the late phase of Deschmann's pile-dwelling sites is whipped cord impressions. This decoration is often combined with impressions using an object with either a sharp or a blunt tip. Vessels decorated in this manner are most characteristic of the Ljubljana culture. This decoration is also to be found on several footed bowls formally linked to the Vučedol tradition, including a crossfooted bowl (Fig. 2: 24) and two others on a high solid and round foot. ${ }^{75}$ These bowls combine a form typical of the Vučedol culture and decoration typical of the Ljubljana culture, pointing to a continuous development from the early to the late phase of Deschmann's pile-dwelling sites (Fig. 3: cf. 9-10 with 11-12).

Ties to the Vučedol culture can also be observed in other kinds of pottery from the late phase (Fig. $3)$, for example in the biconical and globular, mainly undecorated jugs of Types V1 and V2 (Fig. 3: cf. 3-4 with 1-2), single-handled oval jars with studs on the shoulder (Fig. 3: cf. 19 with 17-18) (6) $^{76}$ and high bowls and cups with a concave neck of Types Vs3 and Sk6, ${ }^{77}$ formally similar to the cups with a strap handle of the Vučedol culture (Fig. 3: cf. $7-8$ with $5-6) .{ }^{78}$ The Vučedol tradition is also recognised in some of the motifs adorning the pottery of the Ljubljana culture, such as opposing hatched triangles and wavy lines flanked by two parallel impressed/incised lines and stabs between individual ridges (Fig. 3: cf. 20 with 21 and 22 with 23-25).

Some of the pottery forms of the Ljubljana culture reflect elements connected with the tradition of the central European Corded Ware ${ }^{79}$ and Globular Amphora cultures, ${ }^{80}$ broadly dated to the first half

75 Leghissa 2017, Pl. 98: 5; 109: 2,3 (Korošec, Korošec 1969, Pl. 37: 1; 38: 2; 41: 7; 113: 5).

76 See e.g. Leghissa 2017, Pl. 59: 1-5; 60: 1-4 (Korošec, Korošec 1969, Pl. 12:5,6; $21: 2 ; 23: 11 ; 24: 8 ; 26: 5 ; 27: 1,3 ; 62: 9)$.

77 E.g. Leghissa 2017, Pl. 86: 1-5 (Korošec, Korošec 1969, Pl. 33: 4,6,7; 56: 10; 14).

${ }^{78}$ No such vessels came to light at Deschmann's sites, but they are widespread at the Croatian sites of the Vučedol culture: see e.g. Dimitrijević 1979, 287, 290 ff, Fig. 10: 11,15-17, e.g. Pl. 27: 2; 29: 1,5; 30: 9.

79 Schnurkeramik Kultur in German.

80 Kugelamphoren Kultur in German.

$\leftarrow$

Fig. 2: Characteristic pottery types of the late phase of Deschmann's pile-dwelling sites. Scale $=1: 5$.

Sl. 2: Značilni tipi keramičnih posod mlajše faze Dežmanovih koliščih. M. = 1: 5 .

(After / Po Leghissa 2017, Pl. / t. 2: 2; 3: 8; 31: 1,2; 43:1,6; 44: 1; 49:2,8; 59: 1; 67: 5; 70: 1; 71: 1; 81: 3; 84: 3; 86: 1; 88: $1 ; 89: 3 ; 90: 6$; 97: 5; 98: 5; 104: 3; 111:1,5;112:1;116:1;117: 1; 118:1,5;125:1;125:1) 


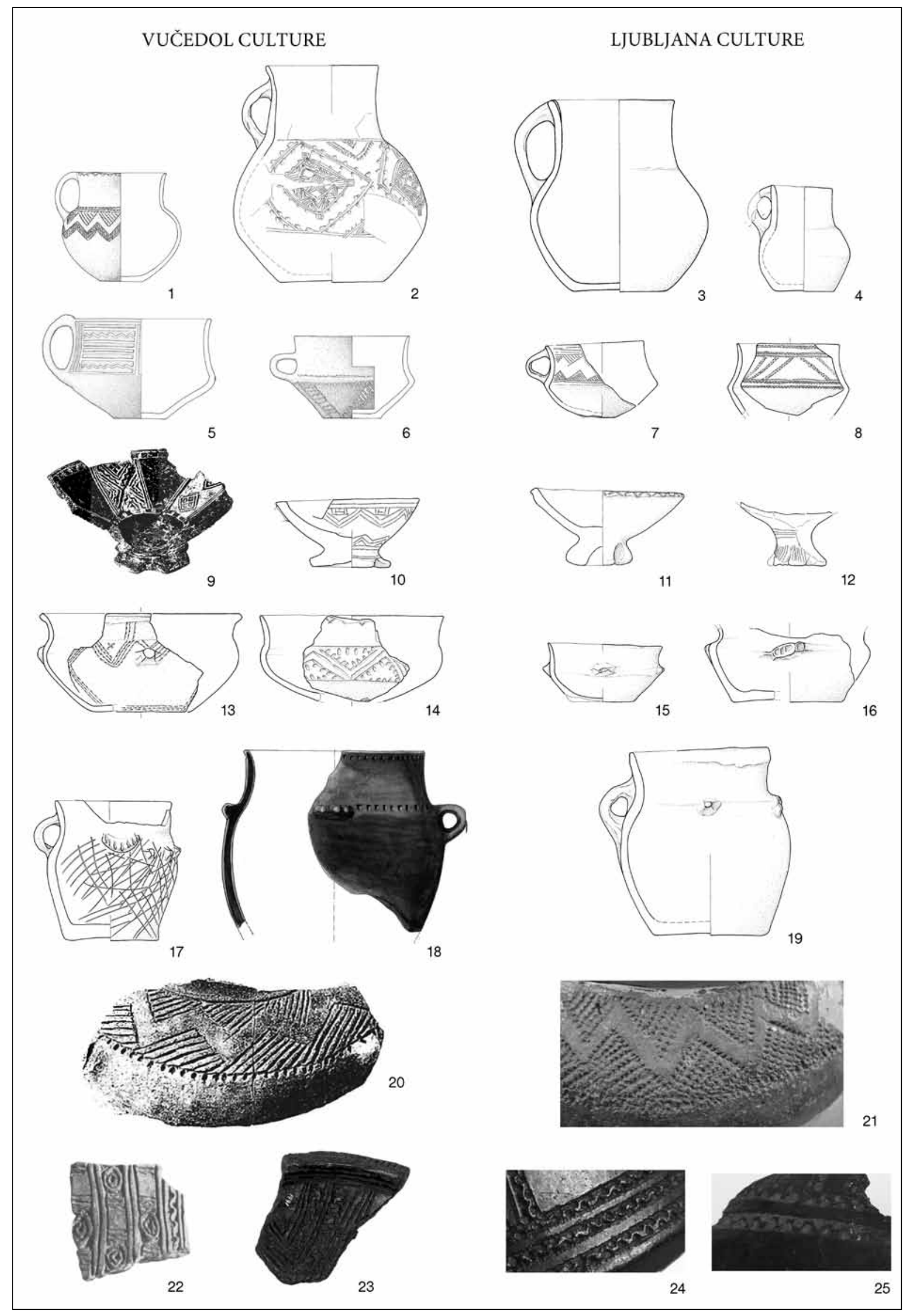


of the $3^{\text {rd }}$ millennium BC. ${ }^{81}$ One such form is the globular two-handled vessels with a cylindrical or funnel-shaped neck of Type DvP4 (Fig. 4), known in the Karst, ${ }^{82}$ but also across the eastern Adriatic (Fig. 4: 3,5-6). ${ }^{83}$ Similarly decorated pottery sherds have come to light in northern Italy, particularly the sites of the Bell Beaker culture. ${ }^{84}$ Their origin should be sought in the area of the Globular Amphora and/or Corded Ware cultures, where the typical forms include globular vessels usually with a cylindrical neck and four or two handles or tunnel-shaped grips, with an apparent similarity between these and the examples from Deschmann's pile-dwelling sites (Fig. 4: 7-10). ${ }^{85}$

81 See e.g. Szmyt 1996, 3 ff; Müller 2001, 210, 222, Fig. 101; 102; Furholt 2003; 2008.; Szmyt 2010, 7 ff, 52 ff; the influences of the Corded Ware culture are already observable in the early phase of Deschmann's sites, i.e. the Ljubljansko barje variant of the Vučedol culture after Leghissa $(2017,259-261)$.

82 See e.g. Tomičeva jama near Škocjan - Map 1: 9 (Battaglia 1958-1959, 396, 397, Fig. 152); Podmol near Kastelec - Map 1: 11 (Turk et al. 1993, Pl. 14: 15; 16: 5,15-17); Grotta del Mitreo/Mitrejeva jama - Map 1: 14 (Montagnari Kokelj, Crismani 1997, Fig. 13: 109; 31: 278); Grotta Cotariova/Čotarjeva jama - Map 1: 25 (Lonza 1973-1974, Fig. 2: 18; 3: 16; 5: 12); Grotta Caterina/Katrna jama - Map 1: 19 (Cannarella, Pitti 1978-1981, Fig. 5: 3-5).

${ }^{83}$ See e.g. Pećina kod Srbani - Map 1: 27 (Čuka 2009, Pl. 3: 13); Otišić-Vlake - Map 1: 36 (Milošević, Govedarica 1986, Pl. 1: 1; 2: 5-9; 3: 1,7; 4: 6; 6: 4); Marina near Split Map 1: 37 (Radić Rossi 2011, 117-118, Pl. 1: 1-2); Čitluk - Map 1: 34 (Marović 1980, 34, Fig. 8); Odmut - Map 1: 48 (Marković 1974, 9, Pl. 4: 1,2,7,9; Marković 1985, Pl. 29: 2,3,6,7); Zelena pećina south of Mostar - Map 1: 42 (Marijanović 1978, Pl. 1: 2); Badanj near the settlement at Borojevići near Stolac in Herzegovina - Map 1: 44 (Marijanović 1978, 177 ff, Pl. 1: 1).

${ }^{84}$ E.g. Nicolis 1998a, Fig. 1: 1,2; 2 : 1-16 (mostly sherds that do not reveal whether the vessels had a cylindrical, slightly funnel-shaped neck); also see Gilli, Petrucci, Salzani 2000, 126, Pl. V: 13.

85 See e.g. Buchvaldek 1967, Fig. 2: A20,A21; 3: A25b; Beran 1992, Fig. 3; Włodarczak 2006, 121 ff, Pl. 14; 23: 4; Furholt 2003, 131 ff; Furholt 2008, 11 ff, Fig. 8; 9.
Different researchers dealing with the Ljubljana culture have noted that its finds include elements that reflect 'contacts' with the Bell Beaker culture. ${ }^{86}$ These elements are the funnel-shaped necks on vessels such as the Type V4 jugs, two-handled vessels of Type DvP4b and the Types B1 and B2 gourds (Fig. 2: 1-3,7-9), as well as the distribution of decorative motifs in bands composed of simple triangles, zigzag lines or reticular designs. ${ }^{87}$ Both cultures also employ a similar decorative technique, i.e. impressions with a cord whipped around a flat object. In the Bell Beaker culture, this decoration is also known as barbed-wire or barbelé in French. ${ }^{88}$ The pottery with barbed-wire decoration is genetically linked to the Bell Beaker phenomenon and dated to the transition from the Late Copper to the Early Bronze Age. It is particularly common in northern Italy and south-eastern France, where it marks the final phase of the Bell Beaker culture - Épicampaniforme - dated roughly to $2150-1900 \mathrm{BC}^{89}$ In the opinion of Franco Nicolis ${ }^{90}$ and other researchers, ${ }^{91}$ the influences for it probably came from the Ljubljana culture of the Ljubljansko barje. ${ }^{92}$ As for northern Italy, this hypothesis is not readily verifiable due to the

${ }^{86}$ E.g. Korošec 1958-1959, 99; Dimitrijević 1967, 10 ff; Gilli, Montagnari Kokelj 1993, 158 and others.

${ }^{87}$ See e.g. Leghissa 2017, Pl. 32: 2; 43: 1; 44: 3-4; 45: 1-2; 47: 6; 84: 3-4; 85: 3-9 and others (Korošec, Korošec 1969, Pl. 34: 2-4; 35: 8,9; 36: 1; 49: 12; 54: 10; 55: 1,3; 56: $1,5,8,15 ; 57: 12 ; 60: 4 ; 115: 1,4 ; 116: 2,5 ; 118: 6,9)$.

88 In Italian a filo avvolto or filo spinato.

${ }^{89}$ See e.g. Nicolis 1998a, 447-464, Fig. 1: 1-2; 2: 21-16; Nicolis 1998b, 57; Strahm 1998, 40; Gilli, Petrucci, Salzani 2000, 125-126; Lemercier et al. 2003, 248-249; Lemercier 2004, 228, Fig. 1; Vital, Convertini, Lemercier 2012, 1 ff, $91 \mathrm{ff}, 97 \mathrm{ff}, 109$. Pottery with such decoration is also widespread in the northern parts of central Europe and south-eastern England, where it is again characteristic of the final phase of the Bell Beaker culture (see e.g. Nicolis 1998a, 449; Czebreszuk, Szmyt 2012, 166, Fig. 11).

90 Nicolis $1998 \mathrm{a}, 455 \mathrm{ff}$.

91 E.g. Lemercier et al. 2003, 243, 248-249.

92 Nicolis 1998a, 455 ff.

$\leftarrow$

Fig. 3: Select forms and decoration of the Vučedol culture in Slavonia and at Deschmann's pile-dwelling sites (left) and examples of the Ljubljana culture pottery from Deschmann's pile-dwelling sites that reflect the tradition of the Vučedol culture (right). Scale $=1-8,10-19=1: 5 ; 9,20-25$ different scales.

Sl. 3: Izbor oblik in okrasa na lončenini vučedolske kulture z območja Slavonije in Dežmanovih kolišč (levo) ter primerov posod ljubljanske kulture z Dežmanovih kolišč, ki odražajo tradicijo vučedolske kulture (desno). M. 1-8,10-19 = 1:5; 9,20-25 različna merila.

Ig - Dežmanova kolišča: 2-4, 7, 8, 11-17, 19, 21, 23-25 (after / po Leghissa 2017, Pl. / t. 2: 2; 3: 1; 17: 1; 44: 4; 58: 1; 59: 1 ; 81: 1,3,5; 82: 2; 86: 5; 91: 1a,2; 98: 5; 109: 3; 116: 1; 118: 5,7); Sarvaš: 1, 5, 6 (after / po Rajković, Balen $2016, \mathrm{Pl}$. / t. 36: 221; Balen 2005, Pl. / t. 33: 118; 34: 120); Vinkovci-Tržnica: 9, 20, 22 (after / po Dimitrijević 1966, Pl. / t. 7: 9; id. 1979, Pl. / t. 32: 3a; 33: 6); Ervenica: 18 (after / po Miloglav 2016, Pl. / t. 22: 1). 


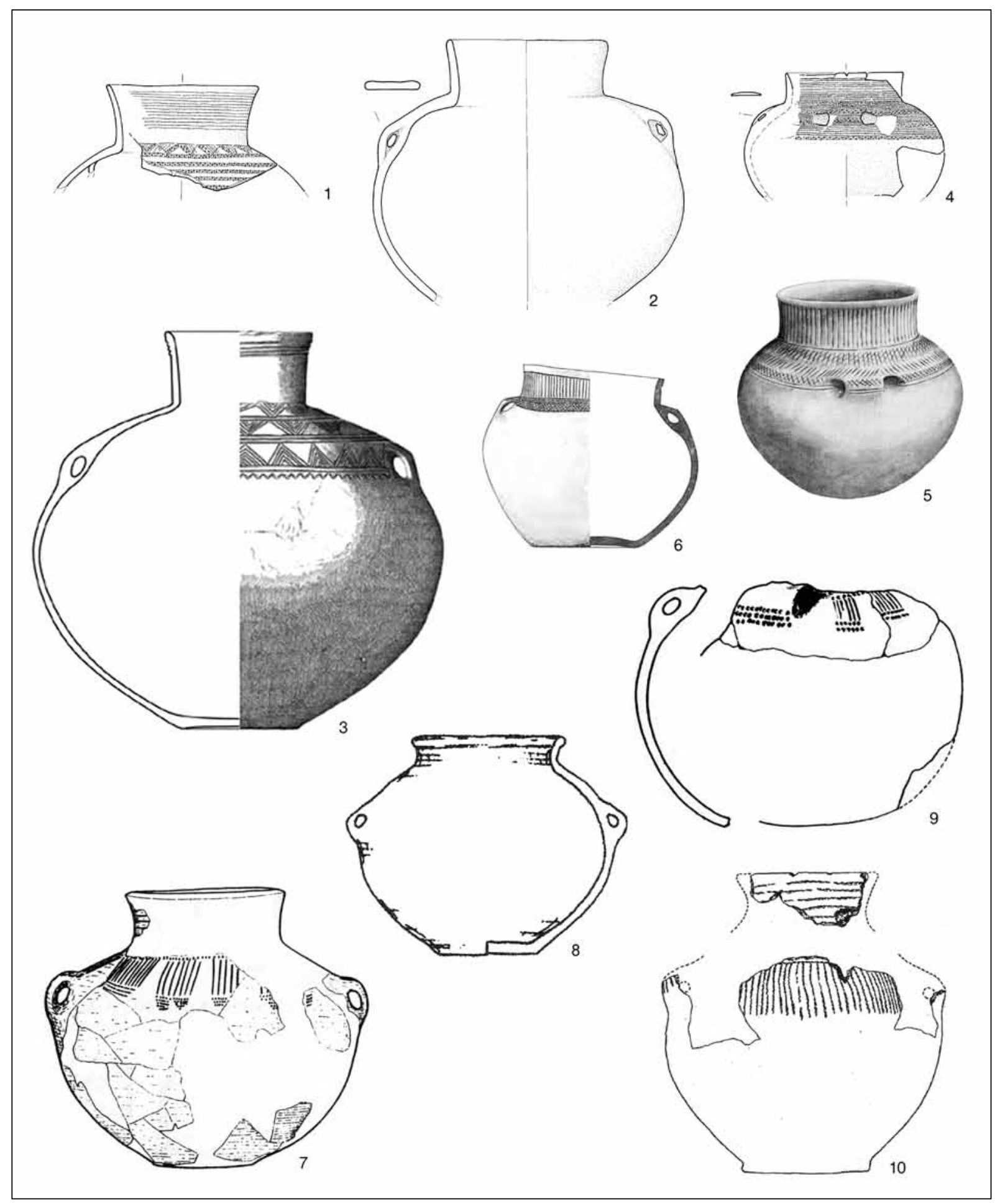

Fig. 4: Comparison of the globular two-handled vessels. Different scales.

Ljubljana culture and its Adriatic variant: 1, 2, 4 Deschmann's pile-dwelling sites near Ig; 3 Marina; 5 Otišić-Vlake; 6 Čitluk (Tumulus 3). - Globular Amphora culture: 7, 9. - Corded Ware culture: 8, 10.

Sl. 4: Primerjava kroglastih dvoročajnih posod. Različna merila.

Ljubljanska kultura in njena jadranska varianta: 1, 2, 4 Dežmanova kolišča pri Igu; 3 Marina; 5 Otišić-Vlake; 6 Čitluk (gomila 3). - Kultura kroglastih amfor: 7, 9. - Kultura vrvičaste keramike: 8, 10.

[1,2,4 (from / po Leghissa 2017, Pl. / t. 43: 1,6; 44: 1); - 3 (from / po Radić Rossi 2011, Pl. / t. 1: 1); - 5 (from / po Milošević, Govedarica 1986, Pl. / t. 1: 1); - 6 (from / po Marović 1980, Fig. / sl. 8); - 7,9 (from / po Beran 1992, Fig. / sl. 3); - 8,10 (from / po Furholt 2003, Pl. / t. 16: 4; 69: 3)] 
small number of pottery decorated in this manner, with the exception of that from the Bernardine di Coriano site. Some forty variously-sized sherds of such pottery came to light here; some forms can undoubtedly be connected with the Bell Beaker culture, ${ }^{93}$ some are similar to those of the Ljubljana culture. ${ }^{94}$ There are no radiocarbon dates available for the barbed-wire pottery from northern Italy. In general, such pottery marks the last phase of the Bell Beaker culture, which in absolute terms postdates by almost 400 years the dating of the Ljubljana culture sites in the Ljubljansko barje. This long gap also raises the question of whether the Ljubljansko barje area and its Ljubljana culture had anything at all to do with the appearance of such decoration in northern Italy and southern France.

Deschmann's Pile-dwelling Site II is also the origin of the only piriform vessel with a decoration similar to that on the bell beakers (Fig. 5: 1), but of a form different from the classic bell beakers that usually have an everted rim. ${ }^{95}$ Its decoration consists of five horizontal bands of incised lines and stabs and is comparable with some of the decoration on the pottery of the Bell-Beaker package (set campaniforme in Italian). ${ }^{96}$

Elements indicating contacts with this culture can also be observed on items from Deschmann's pile-dwelling sites ${ }^{97}$ other than pottery (Fig. 5). The finds typical of the Bell Beaker culture include undecorated common ware (Begleitkeramik in German), as well as awls and daggers of copper, arrowheads and daggers of quartz and bone wrist-guards, whetstones, bone buttons, pendants of wild boar fangs and teeth of different animals. ${ }^{98}$ Typologically similar finds were also recovered at Deschmann's pile-dwelling sites. Among the metal finds, we should mention awls with a lozengeshaped widening in the upper part (Fig. 5: 4). ${ }^{99}$ Similar awls ${ }^{100}$ were also found in the Trento area

93 E.g. Gilli, Petrucci, Salzani 2000, Pl. IV: 1,3,5.

94 Ib., Pl. IV: 6; V: 13.

95 Besse 2004, Fig. 2.1.

96 Dvorak 1993, Pl. 136: 1,8; Peška, Kalábek 2012, Fig.

3: 10; Leghissa 2017, 190, Pl. 127: 4.

97 Mostly at Deschmann's Site II.

98 See e.g. Strahm 1998, 27-29; Heyd 2001, Fig. 4; Turek 2006, Fig. 5; 13; 17; 18; Müller 2013, Fig. 1 and others.

99 Korošec, Korošec 1969, Pl. 105: 1-5; Trampuž Orel, Heath 2008, Pl. 1: 12,13.

100 In contrast with the awls from Deschmann's piledwelling sites, they have a pointed rather than a flat tip and a round-sectioned shank. in northern Italy, ${ }^{101}$ together with pottery sherds of the Bell Beaker culture. ${ }^{102}$ The Italian researchers posit that these awls mirror influences or contacts with the Ljubljana culture and identify them as awls of the Ig II type. ${ }^{103}$ With a single exception, the copper daggers from Deschmann's pile-dwelling sites (Fig. 5: 3) ${ }^{104}$ have a tang and are comparable with numerous daggers unearthed across wide areas between the River Dnieper, the Carpathians and Greece in the east to western Europe and particularly on the Iberian Peninsula. ${ }^{105}$ They have a broad time span, covering the first half of the $4^{\text {th }}$ and most of the $3^{\text {rd }}$ millennium BC. ${ }^{106}$ Elongated oval whetstones (Fig. 5: 6) ${ }^{107}$ mainly occur in the graves of the Bell Beaker culture from Moravia to Saxony and Bavaria. ${ }^{108}$ The stone artefacts from Deschmann's pile-dwelling sites include quartz leaf-shaped bifacially retouched spearheads or daggers (Fig. 5: 5). ${ }^{109}$ They have close parallels from sites in the Triestine Carso ${ }^{110}$ and northern Italy in general, ${ }^{111}$ for example at Montesei di Serso in Trento. ${ }^{112}$ Among the most interesting from Deschmann's pile-dwelling sites is a flat object decorated with short incisions and bearing holes along both long and one of the short sides (Fig. 5:

101 Perini 1972, Fig. 9: 137; 10: 140,141; Bagolini, Pasquali, Pedrotti 1985, Fig. 2; Nicolis 1998a, 460 (Fn. 48).

102 E.g. Mottes, Nicolis 1998, 73 ff, Fig. 1; 4.

${ }^{103}$ During my visit to the museum in Vučedol and the examination of the as yet unpublished finds, I came across an illustration of a similar awl with a lozenge-shaped widening, but with a round-rather than rectangular-sectioned shank; it was excavated at Vučedol in 1987. The context and age of the awl are as yet unknown.

104 Korošec, Korošec 1969, Pl. 105: 6-11.

105 See Trampuž Orel, Heath 2008, 27 with references; a similar dagger is also known from the Bell Beaker culture in Moravia (see Turek 2006, Fig. 5: 11).

106 E.g. the dagger found in Grave R2 on the Greek island of Lefkada is dated to EH II (roughly 2650-2200 BC) (Branigan 1975, 37). Similar daggers are also known from Ezero in Bulgaria, the site that yielded two radiocarbon dates with a range of 3522-3031 cal BC (98.7\%) and 2911-2464 cal BC (100\%) (Primas 1996, 168; Fig. 7.7: 6,7), etc.

107 Korošec, Korošec 1969, Pl. 77: 1-7.

108 See e.g. Turek 2006, Fig. 5: 29-30; 18: 7-8; 23: 6; 74.

109 Korošec, Korošec 1969, Pl. 73: 1-11; 74: 1-10; 75: 1; there are no quartz arrowheads among the finds from Deschmann's pile-dwelling sites, while numerous examples came to light at the pile-dwelling sites at Špica (unpublished, kept in the city museum: Muzeji in galerije mesta Ljubljane).

110 Gilli, Montagnari Kokelj 1996, Fig. 35

111 E.g. Barfield 2001, 510 ff; Mottes 2001, 519 ff, Fig. 1.

112 Mottes 2001, Fig. 4 (cf. Korošec, Korošec 1969, Pl. 74: 1,3). 


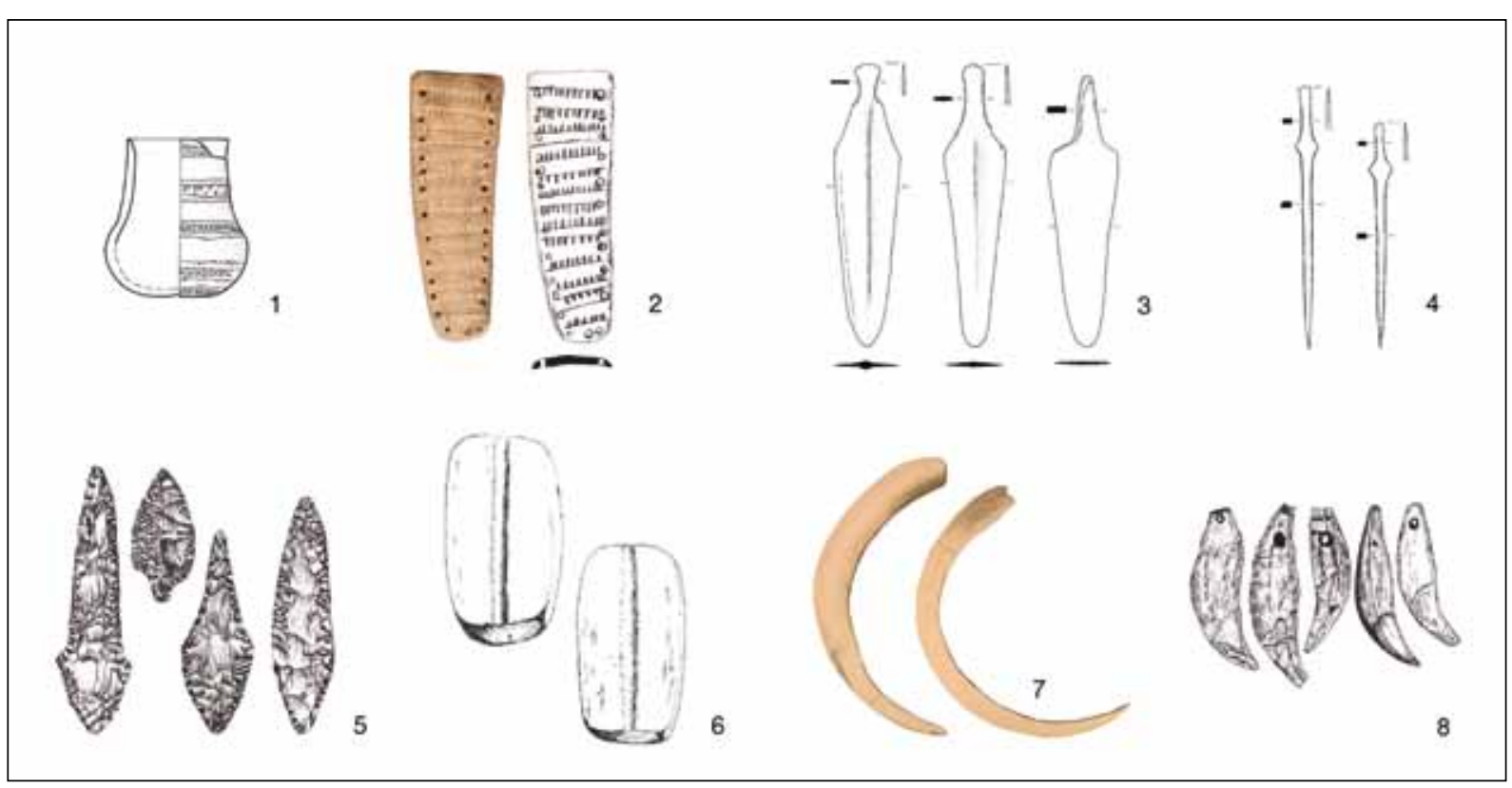

Fig. 5: Finds from Deschmann's pile-dwelling sites that reflect contacts with the Bell Beaker culture. Scale = 1:4. Sl. 5: Najdbe z Dežmanovih kolišč, ki odražajo stike s kulturo zvončastih čaš. M. = 1:4.

[1 (after / po Leghissa 2017, Pl. / t. 127: 4); - 3,4 (after / po Trampuž Orel, Heath 2009, Pl. / t. 1: 8-10,12,13); - 2,5,6,8 (after / po Korošec, Korošec 1969, Pl. / t. 73: 4,5,11; 74: 1; 77: 3,4; 87: 2-6); - 2,7 (photo / foto: Arheološki oddelek NMS, arhiv)]

2). ${ }^{113}$ Its function is not completely certain, though its size, shape and curvature make it similar to the wrist-guards or bracers ${ }^{114}$ characteristic of the Bell Beaker, Polada and Cetina cultures. ${ }^{115}$ According to J. Kleijn, such bone plates could have served either as wrist-guards, belt buckles or for some other, as yet unidentified purpose. ${ }^{116}$

The vessels of the Ljubljana culture from Deschmann's pile-dwelling sites show numerous similarities with the finds from the Karst, as well as the eastern Adriatic littoral, which Dimitrijević identified as the Adriatic variant of the Ljubljana culture (Map 1). ${ }^{117}$ For Dimitrijević and other authors, ${ }^{118}$ this variant includes finds from the tumuli in Montenegro and Albania that are dated to the early $3^{\text {rd }}$ millennium $\mathrm{BC}$, for example from Mala Gruda and Velika Gruda, ${ }^{119}$ Podgorica-

113 Korošec, Korošec 1969, Pl. 87: 1.

114 In German Armschutzplatte; in Italian bracciale d'arciere or brassard. Blagoje Govedarica interpreted this object as a belt buckle (Govedarica 1989, 45; Pl. XI: 1).

115 E.g. Turek 2013; 2015; Forenbaher 2013, 94.

116 Kleijne 2019, 136.

117 Dimitrijević 1967; also see Korošec 1962; Govedarica 1989.

118 See e.g. Govedarica 1989; 2016; Marijanović 1991; 2003; Zagarčanin 2016; Forenbaher 2018a,b.

119 E.g. Govedarica 1989; Primas 1996.
Gruda Boljevića, ${ }^{120}$ Mogila na Rake, ${ }^{121}$ Kujava near Danilovgrad ${ }^{122}$ and others.

Having said that, the pottery from these tumuli is closer in form and even more so the decorative motifs to the Vučedol culture than the Ljubljana or Adriatic variant of the Ljubljana culture. The footed bowls from the tumuli ${ }^{123}$ are adorned with incisions, stabs and hollowed surfaces, which is characteristic of the Vučedol culture. The only exception is the footed bowl from the tumulus at Kujava near Danilovgrad, which is described as bearing roulette decoration, ${ }^{124}$ though the published photo does not allow us to confirm the use of this particular decorative technique. ${ }^{125}$ The crossshaped decoration on the exterior and interior is also closer to the ornamental syntax of Vučedol

120 E.g. Guštin, Preložnik 2015.

121 Zagarčanin 2016.

122 Lutovac 2017.

123 E.g. Govedarica 1989, Pl. 42: 1 a-b; 44: 1a-c; Primas 1996, Fig. 5.1; 5.2; 5.3; 5.4; Guštin, Preložnik 2015, Fig. 4: 1; Zagarčanin 2016, Fig. 3: c,f; 5; 6. Not having had the opportunity to inspect the objects personally, I identify the pottery based on the published descriptions and particularly the photographs and drawings.

124 Lutovac 2017, 61, Pl. 8.

125 The published photograph allows for the decoration on the bowl to be identified as impressions of a doubletwisted cord. 
pottery. ${ }^{126}$ In addition to bowls, the decorated ceramic jugs placed into the graves of these tumuli are also similar to those of the Vučedol culture. ${ }^{127}$ These jugs are decorated on the lower body and the neck, ${ }^{128}$ similarly as the Vučedol two-handled vessels. ${ }^{129}$ Rather than to the Adriatic variant of the Ljubljana culture, ${ }^{130}$ all these features rather lead me to ascribe the tumuli from Montenegro, similarly as Maran, to the Montenegro variant of the Vučedol culture. ${ }^{131}$

Sites in the Karst, as well as the eastern Adriatic littoral provide close parallels for different vessels from Deschmann's pile-dwelling sites, attributed to the Ljubljana culture, for example the globular two-handled vessels with a cylindrical or funnelshaped neck of Type DvP4 (Fig. 2: 3,4,9), ${ }^{132}$ high bowls with a globular body and a funnel-shaped neck of Type Vs2 (Fig. 2: 14), ${ }^{133}$ high bowls with a curved neck of Type Vs3 (Fig. 2: 12), ${ }^{134}$ hemispherical bowls with a thickened rim of Type $S 1$ (Fig. 2: 16; 6), ${ }^{135}$ bowls with a hollow conical foot

126 Cf. e.g. Hoffiller 1933, Pl 8: 3a-b; Dimitrijević 1979, Pl. 30: 5; 32: 3a; Balen 2005, Pl. 28: 93,94; Kulcsár 2013, Fig. 4: 1c.

127 See Leghissa 2017, 104-117.

128 Govedarica 1989, Pl. 42: 2; Guštin, Preložnik 2015, Fig. 4: 3; Zagarčanin 2016, Fig. 3: c; 4.

129 See e.g. Dimitrijević 1979, Pl. 33: 1,3,4,8; 36: 5.

130 See e.g. Primas 1996; Maran 1998; 2007; Harrison, Heyd 2007; Guštin, Preložnik 2015.

131 See Maran 2007, 8 ff; Fn. 36; also see Maran 1998, Fn. 243. The hypothesis particularly widespread in recent years is that the Montenegrin tumuli are part of the Yamnaya culture characterised by tumulus burials (see e.g. Harrison, Heyd 2007; Heyd 2011).

132 Cf. e.g. Battaglia 1958-1959, 396, 397, Fig. 152; Lonza 1973-1974, Fig. 2: 18; 3: 16; 5: 12; Marković 1974, 9, Pl. 4: 1,2,7,9; Marijanović 1978, 177 ff, Pl. I: 1; Cannarella, Pitti 1978-1981, Fig. 5: 3-5; Marović 1980, 34, Fig. 8; Marković 1985, Pl. 29: 2,3,6,7; Milošević, Govedarica 1986, Pl. 1: 1; 2: 5-9; 3: 1,7; 4: 6; 6: 4; Turk et al. 1993, Pl. 14: 15; 16: 5,15-17; Montagnari Kokelj, Crismani 1997, Fig. 13: 109; 31: 278; Gilli, Petrucci, Salzani 2000, 126, Pl. 5: 13; Marijanović 2003, Pl. 21: 1,6; 25: 5; 26: 3; Čuka 2009, Pl. 3: 13; Radić Rossi 2011, 117-118, Pl. 1: 1-2 and elsewhere.

133 Cf. e.g. Korošec 1956, Pl. 2: 3; 3: 2,5: 3; Dimitrijević 1967, Pl. 7: 4; Forenbaher, Vranjican 1985, Pl. 5: 2,3; Montagnari Kokelj, Crismani 1997, Fig. 12: 93; 13: 107,109; Gilli, Montagnari 1996, Fig. 38: 255; Montagnari Kokelj, Greif, Presello 2002, Pl. 11: 119 and elsewhere.

134 Cf. e.g. Dimitrijević 1967, Pl. 7: 1; Milošević, Govedarica 1986, Pl. 9: 1-3; 10: 2?; Turk et al. 1993, Pl. 14: 22; 16: 18; Montagnari Kokelj, Crismani 1997, Fig. 13: 106.

135 Cf. e.g. Lonza 1973-1974, Fig. 2; Milošević, Govedarica 1986, Pl. $1: 3 ; 7: 1-3,5 ; 8: 3,5,6 ; 9: 6 ; 10: 3 ; 11: 1 ; 12$ : of Type SnN9 (Fig. 2: 18,19) ${ }^{136}$ and globular cups with a funnel-shaped neck of Type Sk 5 (Fig. 2: $10,11,15) .{ }^{137}$ All this pottery and its parallels bear the same or similar decoration, ${ }^{138}$ of whipped cord impressions often in combination with stabbing.

There are differences in the material culture between the Ljubljansko barje and the rest of the distribution area of the Ljubljana culture, ${ }^{139}$ mainly in the number and diversity of pottery forms. Compared with the pottery from the Ljubljansko barje, particularly Deschmann's pile-dwelling sites, the eastern Adriatic littoral is marked with a complete absence of globular jugs with a funnel-shaped neck of Type V4 (Fig. 2: 1,2,5) and gourd-like vessels (Fig. 2: 6-8). As for the decorative motifs, differences are most clear in the bowls of Type S1 with a flat (sometimes obliquely) cut rim, examples of which from the Adriatic littoral are more richly decorated not only at the rim and in the upper part, but frequently also on the whole exterior surface (Fig. 6: 7-17), while the bowls from the caves in the Trieste Karst and one example from Istria is decorated almost identically to the bowls from the Ljubljansko barje $\mathrm{e}^{140}$ (Fig. 6: cf. 1 with 2-6). ${ }^{141}$

1; Barfield 1997-1998, Fig. 12: 46,47; Hulina, Forenbaher, Miracle 2011, 159, 161, Fig. 16: 3.f; Pl. 4: 5 and elsewhere. 136 Cf. e.g. Milošević, Govedarica 1986, Pl. 1: 5; 8: 1; 11: 13; 12: 2; Govedarica 1989, Pl. 19: 8a-b.

137 Cf. e.g. Lonza 1973-1974, Fig. 4: 12; Forenbaher, Vranjican 1985, Pl. 5: 1; Gilli, Montagnari Kokelj 1993, Fig. 35: 341; 43: 425; Turk et al. 1993, Pl. 14: 15; Montagnari Kokelj, Crismani 1997, Fig. 12: 94; Čuka 2009, Pl. 3: 14.

138 With the exception of the pottery from the Ljubljansko barje and the Karst, I was unable to personally examine the pottery to verify whether the same decorative technique was applied.

139 Among the main differences is also the site type: those of the Ljubljansko barje are short-lived pile-dwelling settlements, while elsewhere we are mainly dealing with caves visited/inhabited over a longer period, though not uninterruptedly. As has already been mentioned several times, such differences in the material culture may result from the manner and extent of research, but also from actual cultural differences.

140 The only exception is the bowls from the Parte pile-dwelling site, which bears horizontal lines and hatched triangles below the exterior rim (Harej 1978, Pl. 3: 3), i.e. similarly as the examples from the eastern Adriatic littoral. Decorated like the bowls from Deschmann's sites are the unpublished bowls from the pile-dwelling site at Špica in Ljubljana (see e.g. Klasinc et al. 2010, Pl. 12: top left).

141 The differences in decoration are reminiscent of the stylistic changes in the Bell Beaker culture. For the Bell Beaker culture in northern Italy, Nicolis observed an intriguing development/change, from a simple zonal deco- 


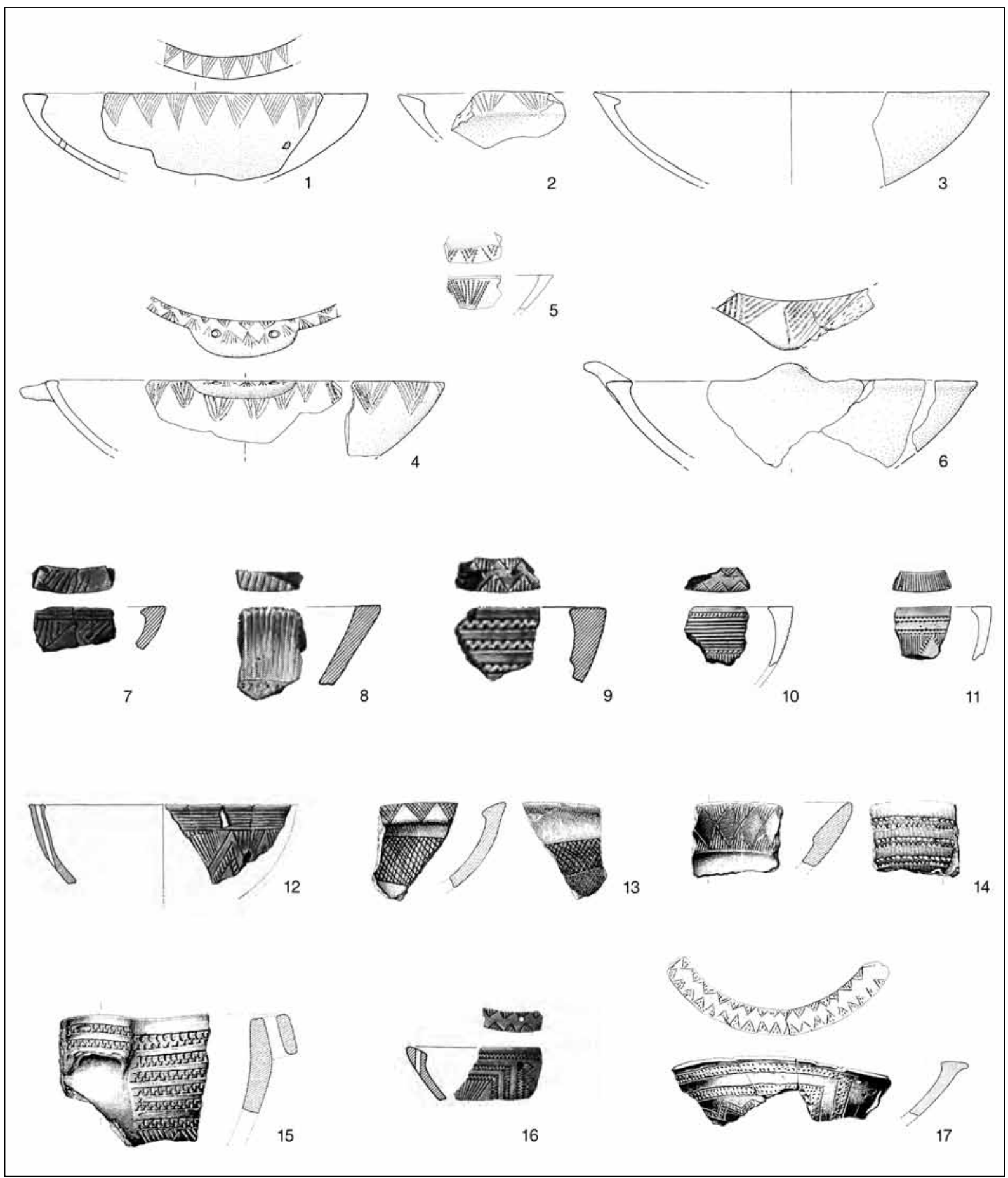

Fig. 6: Comparison of the bowls with a flat rim. Different scales.

Sl. 6: Primerjava skled z ravno odrezanimi robovi. Različna merila.

1 - Dežmanova kolišča (Map / karta 1: 1) (after / po Leghissa 2017, Pl. / t. 88: 2);

2, 3 - Grotta Teresiana/Terezijina jama (Map / karta 1: 15) (after / po Barfield 1997-1998, sl. / Fig. 12: 46,47);

4, 6 - Grotta degli Zingari/Ciganska jama (Map / karta 1: 21) (after / po Gilli, Montagnari Kokelj 1996, sl. / Fig. 42: 299,300);

5 - Pupićina pećina (Map / karta 1: 28) (after / po Hulina, Forenbaher, Miracle 2011, Pl. / t. 4: 5);

7 - Rudine (Map / karta 1: 33) (after / po Govedarica 1989, Pl. / t. 26: 7);

8-12 - Otišić-Vlake (Map / karta 1: 36) (after / po Milošević, Govedarica 1986, Pl. / t. 7: 2,5; 8: 3,5; 9: 6; 10: 3);

13-15 - Ravlića pećina (Map / karta 1: 40) (after / po Marijanović 2003, Pl. / t. 5: 1-3);

16 - Orađe (Map / karta 1: 41) (after / po Govedarica 1989, Pl. / t. 26: 6);

17 - Hateljska pećina (Map / karta 1: 46) (after / po Marijanović 2003, Pl. / t. 19: 1). 
The pottery ascribed to the late phase of Deschmann's pile-dwelling sites include the pottery of the Ljubljana culture and vessels that reflect old elements of the Vučedol (of the Ljubljansko barje variant), Corded Ware and Globular Amphora cultures, as well as new influences of the Bell Beaker culture, but there are also vessels with parallels primarily in the Somogyvár-Vinkovci and Makó-Kosihy-Čaka cultures. The latter include, for example, large two-handled oval vessels for storage (Fig. 2: 29), ${ }^{142}$ vessels with a thickened rim (Fig. 2: 30), ${ }^{143}$ conical bowls (Fig. 2: 23) $)^{144}$ and hemispherical cups (Fig. 2: 25). ${ }^{145}$

Similar vessels have also come to light at other $3^{\text {rd }}$-millennium pile-dwelling sites in the Ljubljansko barje, for example at Parte (Fig. 7: 17-24; Map 1: 2), Založnica near Kamnik pod Krimom (Map 1: 4), Dušanovo (= Črni graben) (Map 1: 5,6) and Špica (Map 1: 7). In the publication of the Založnica site, ${ }^{146}$ Velušček and Čufar note the similarities with the finds from Parte and cite closest parallels from Börzönce in Hungary, a site attributed to the Somogyvár-Vinkovci culture, to which they also ascribe Založnica and Parte. ${ }^{147}$ These parallels are certainly correct, but there are also differences. The array of finds from Založnica and Parte (as well as Deschmann's and other pile-dwelling sites of the $3^{\text {rd }}$ millennium $\mathrm{BC}$ ) is

ration to an increasingly baroque-style horror vacui visible in a gradual filling of empty spaces (Nicolis 1998b, 61).

${ }^{142}$ Leghissa 2017, Pl. 70: 1-2 (Korošec, Korošec 1969, Pl. 8: 4; 21: 3), cf. e.g. with Vladár 1962, Pl. I: 7; Marković 1978, 24, Pl. VIII: 2; Marković 1981, Pl. 7: 9; 8: 5; Tasić 1984, Pl. III: 4,5,7; IV: 2,7,10; Bandi 1984, Pl. XXVIII: 1; Bondár 1994, Fig. 3: 1; Bondár 1995, 205, Fig. 14: A/3, Pl. 172: 323; Ruttkay 2003, Fig. 4; Kulcsár 2009, 154 ff, 334; Fig. 35: XIV/1; 67: XV/1,2,3; Vollmann 2009, Pl. 2: 12; Šavel, Sankovič 2010, 53, e.g. G147, G180, G181, G399, G565-568, G1335.

${ }^{143}$ Leghissa 2017, Pl. 71: 1-4; 72: 1-5 (Korošec, Korošec 1969, Pl. 63: 4; 65: 2; 66: 1-7), cf. e.g. with Dimitrijević 1966, 30; Kulcsár 2009, 329, Fig. 65: XIV/4 and XIV/4a, Pl. 8: 10; 17: 1; Šavel, Sankovič 2010, G54, G127, G215, G242, G286 and others; Guštin, Zorko 2013, Pl. 1: 10; 2: 9; Kerman 2014, Fig. 1.5: 5; 1.6: 9.

${ }^{144}$ Leghissa 2017, Pl. 90: 4-7 (Korošec, Korošec 1969, Pl. 50: 3,4,7; 65: 7), cf. e.g. with Vladár 1962, Fig. 20: 1; 21 : 4; Toth 2001, Fig. 8: 8; Kulcsár 2009, Fig. 22: VII/11,VII/14; Fig. 26: VII/26; Šavel, Sankovič 2010, 43, Fig. 24: 2.

145 Leghissa 2017, Pl. 112: 1-5 (Korošec, Korošec 1969, Pl. 28: 5; 50: 8,9,11,13; 110: 1); cf. e.g. with Bondár 2003, Fig. 6: 1; 10: 2; Kulcsár 2009, Pl. 11: 3; Šavel, Sankovič 2010, 47 ff, Fig. 25: 1,5; Guštin, Zorko 2013, Pl. 1: 3.

146 Velušček, Čufar 2003.

147 Ib., 129-130. missing a number of pottery forms characteristic of the Somogyvár-Vinkovci culture, such as the jugs with a very high curved or cylindrical neck, high bowls with handles, a sharp carination and a high hollow cylindrical pedestal. ${ }^{148}$

Of crucial importance is that the finds from the above-mentioned sites in the Ljubljansko barje attributed to the Somogyvár-Vinkovci culture occur together with pottery characteristic of the Ljubljana culture. At Parte, a pile-dwelling site investigated in the $20^{\text {th }}$ century, the same cultural layer held finds characteristic of the Ljubljana culture and those that, according to Velušček and his colleagues, can be associated with the Somogyvár-Vinkovci culture. Both groups of finds have come to light in the same excavation area without being spatially distinguishable; their stratigraphic position thus suggests contemporaneity. ${ }^{149}$ At Založnica, Dušanovo and Špica as well, the same cultural layer showed no concentrations of finds and yielded both objects characteristic of the Ljubljana culture and those with parallels in the Somogyvár-Vinkovci culture. Moreover, all these sites were inhabited in a single phase and mostly over a short period of time. ${ }^{150}$

Dimitrijević already noted a potential contemporaneity of the Ljubljana and Somogyvár-Vinkovci cultures, in connection with a sherd of a vessel typical of the Ljubljana culture found during the 1877/78 excavations at Vinkovci, in Trench 55. He ascribed the sherd to the Vinkovci horizon noting that it may have been found in a pit attributed to

148 See e.g. Kulcsár 2009, Fig. 49: I/12-I/16; 51: II/7,II/8; 54: VII/2-5,11,12; 59; 60. See also e.g. Šavel, Sankovič 2010, G6, G10, G13, G31, G32, G141, G209, G371-G373, G430 and others. As has already been mentioned above with regards to the Ljubljana culture, attributing sites in the Ljubljansko barje to the Somogyvár-Vinkovci culture is problematic in terms of the classic cultural approach. The sites in the Ljubljansko barje lie at a considerable distance from the main distribution area of the said culture and stand apart from the other known sites of the cultural phenomenon in location, dating and type of settlement.

149 The Parte-Iščica site, located some $85 \mathrm{~m}$ east of the area excavated by Harej at Parte, is earlier and dated to the late $28^{\text {th }}$ and the $27^{\text {th }}$ century BC. A more detailed cultural analysis of the connections between the two piledwelling sites has as yet not been conducted; some of the finds recovered from the Iščica bed indicate similarities with the Vučedol-phase finds from Deschmann's sites, the Somogyvár-Vinkovci culture and one object also with the finds of the Ljubljana culture, while some with the Litzen pottery of the Early Bronze Age (also see Velušček, Čufar, Levanič 2000).

150 On the unsynchronous curve from the Založnica site, see here Fn. 48. 


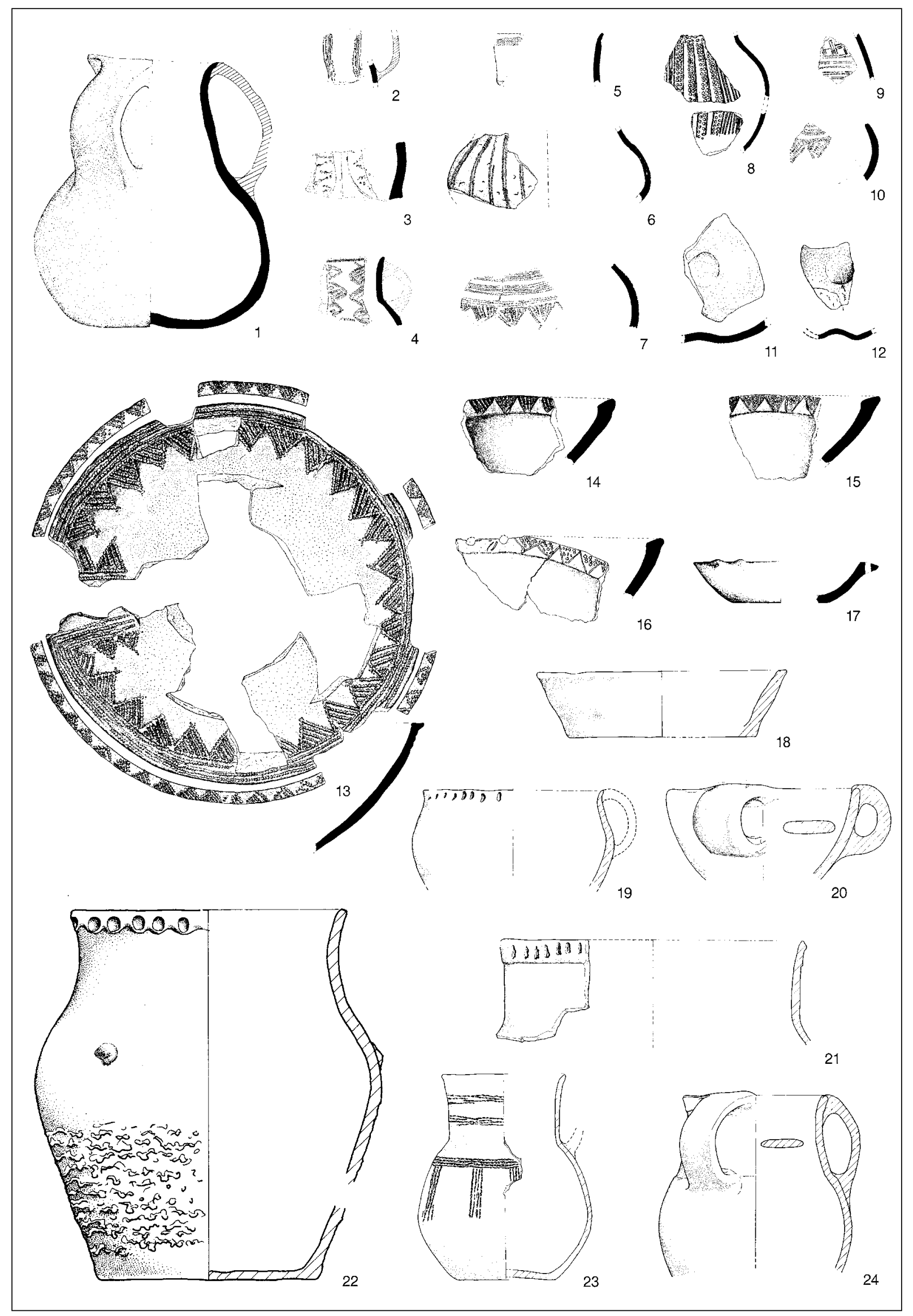


this horizon. ${ }^{151}$ However, the stratigraphy in this trench was disturbed by a pillar erected in the early $20^{\text {th }}$ century; hence the sherd cannot be a reliable argument for a contemporaneity of both cultures.

This raises the question of whether it is at all appropriate to attribute some of the finds from Deschmann's pile-dwelling sites to the SomogyvárVinkovci culture. The main new and characteristic feature of the late phase at Deschmann's pile-dwelling sites is the appearance of the Ljubljana culture pottery, which is predominantly finer and decorated with incisions/impressions. This pottery is less numerous at other sites in the Ljubljansko barje with the exception of Špica ${ }^{152}$ and Parte (see List 1) (e.g. Fig. 7: 1-16). ${ }^{153}$ The largely undecorated and coarse vessels of Phase II at Deschmann's pile-dwelling sites occur alongside vessels linked

151 Dimitrijević 1982, 18; Pl. 8: 5.

152 The pottery of the Ljubljana culture is very common at Špica.

153 The different ratio of the Ljubljana culture pottery and the pottery indicating influences of the Somogyvár-Vinkovci culture may be due to the state of research. A comparison of all the pile-dwelling sites in the Ljubljansko barje is not possible as they were investigated in different extents and with different methods. At Deschmann's sites, excavations covered a roughly $12,836 \mathrm{~m}^{2}$ large area, at Parte only 640 $\mathrm{m}^{2}$. The area investigated at Založnica and Dušanovo (= Črni graben) is difficult to estimate with any precision as archaeologists merely documented the remains that came to light while cleaning the drainage ditches. We also known that Dežman predominantly only collected complete vessels and decorated sherds during the excavations, leaving the bulk of undecorated sherds in the ground. Evidence of the latter is the numerous fragments of undecorated vessels that Tatjana Bregant found in the spoil deposit while trial trenching the area of Deschmann's sites in the 1960s (most recently in Leghissa 2017 with references). There are other possible explanations for the differences between the pile-dwelling sites in the Ljubljansko barje, for example a different status of either a central settlement/area (Deschmann's pile-dwelling sites) or peripheral settlements (at the southern edge of the Ljubljansko barje). As already mentioned in Fn. 139, there are also differences between the pile-dwelling sites of the Ljubljansko barje and other sites of the Ljubljana culture that are of a different type - cave sites. with influences from the Somogyvár-Vinkovci and Makó-Kosihy-Čaka cultures. Not only at the piledwelling sites of the Ljubljansko barje, the decorated fineware of the Ljubljana culture occurs alongside coarse pottery reminiscent of the vessel types of the Somogyvár-Vinkovci culture at the sites in the Karst and the eastern Adriatic littoral. ${ }^{154}$ Interestingly, the pottery of the Bell Beaker culture also consists of the typical decorated vessels and the undecorated coarser vessels, i.e. common ware, ${ }^{155}$ which shares many features with some of the vessel forms of the Somogyvár-Vinkovci, Makó-KosihyČaka and Nagyrév cultures. An example of this is the pottery from the settlement at Albertfalva near Budapest, attributed to the Csepel group of the Bell Beaker culture. ${ }^{156}$ The predominantly coarse and undecorated (or rarely decorated) pottery from the late phase at Deschmann's pile-dwelling sites and from the pile-dwelling site at Parte ${ }^{157}$ should thus be understood as part of the Ljubljana culture, but reflecting certain influences of the SomogyvárVinkovci culture from the Pannonian Plain.

154 E.g. jugs with a biconical or globular body, vessels with a thickened lip, jars with a funnel-shaped neck. See e.g. Podmol near Kastelec - Assemblage D (Turk et al. 1993, Pl. 13: 15,19; 14: 5; 15: 1-3,9; 16:2,6,9,22,23,25,29); in the Triestine Carso, see e.g. Grotta Teresiana/Terezijina jama (Barfield 1997-1998, Fig. 12: 45); Grotta Cotariova/Čotarjeva jama (Lonza 1973-1974, Fig. 4: 10; Barfield 1997-1998, Fig. 15: 25); Grotta degli Zingari/Ciganska jama (Gilli, Montagnari Kokelj 1996, Fig. 37: 231-235; 38: 241,244-249); Grotta dei Ciclami/Orehova pejca(Gilli, Montagnari Kokelj 1993, 154 ff, Fig. 29: 268; 43: 417-422,426; 51: 504,504); in the eastern Adriatic area: Hateljska pećina Phase III (Marijanović 2003, 35 ff, Pl. 8: 2,3; 9: 1-2; 10: 1-4); Varvara A-1 (Čović 1978, Pl. $1 ; 2: 6,7 ; 3: 6 ; 7)$ and elsewhere.

155 In German Begleitkeramik (also see Leghissa 2017, 104-112).

156 Endrődi, Reményi 2016, 108-114, 118-121; the finds from Albertfalva include a bowl fragment with a decoration on the interior rim similar to the pottery of the Ljubljana culture (Endrődi, Reményi 2016, Pl. 4: 6).

${ }^{157}$ Probably also the similar pottery from the pile-dwelling sites at Založnica, Dušanovo (= Črni graben) and Špica.

$\leftarrow$

Fig. 7: Select finds of the Ljubljana culture from the pile-dwelling site at Parte: 1-16 vessels decorated in the Ljubljana culture manner, i.e. with cord whipped around a flat object; 17-24 common ware showing influences from the Somogyvár-Vinkovci culture. Different scales.

Sl. 7: Izbor najdb ljubljanske kulture s kolišča Parte: 1-16 posode okrašene v maniri ljubljanske kulture, tj. z odtisi na ploščat predmet navite niti; 17-24 spremna lončenina, ki kaže na vplive kulture Somogyvár-Vinkovci. Različna merila. Različna merila.

(After / Po Harej 1978, Pl. / t. 1: 7,10,13; 3: 3,4; id. 1981-182, Pl. / t. 15: 1,3,4,7; 16: 2; 20: 5,6,8; 21: 9,10,15; 31: 2; id. 1987, Pl. / t. 5: $1,7,11 ; 8: 1 ; 9: 1 ; 13: 1 ; 16: 1)$ 


\section{ABSOLUTE TIME FRAME OF THE LJUBLJANA CULTURE}

In addition to Deschmann's Site II, the piledwelling settlements of the Ljubljana culture also comprise Parte, Špica, Založnica and Dušanovo. The remains from these sites were sampled for analyses, mostly dendrochronological, ${ }^{158}$ with the results usable in dating the Ljubljana, but not the Somogyvár-Vinkovci culture. Geographically closest to Deschmann's Site II is Parte, which was excavated in 1976-1981. ${ }^{159}$ The $640 \mathrm{~m}^{2}$ large excavation area revealed a cultural layer with a multitude of wooden piles and other finds attributable to the Ljubljana culture, ${ }^{160}$ as well as those reflecting influences of the Somogyvár-Vinkovci culture. ${ }^{161}$ The dendrochronological dates have shown that the earliest construction phase at Parte dates to the late $26^{\text {th }}$, the peak of construction activity to the first half of the $25^{\text {th }}$ and the last phase roughly to the mid- $25^{\text {th }}$ century BC (Fig. 8). ${ }^{162}$ Precise dendrochronological dates are also known for Založnica and Dušanovo, where less forms typical of the Ljubljana culture have come to light and more of the common ware reflecting the Somogyvár-Vinkovci culture. ${ }^{163}$ At Založnica, dendrochronological analyses have shown a ninety-year long period of construction activity that began in the late $26^{\text {th }}$ and ended in the

158 The wiggle-matching method was employed to obtain precise wooden pile chronology, with tree rings from select sections of the pile chronology also radiocarbon dated, some to a 2-sigma accuracy of \pm 10 years (also see Čufar et al. 2010; Velušček, Čufar 2014; Velušček 2014).

159 In this context, we disregard the dendrochronological analyses from the Parte-Iščica pile-dwelling site as the finds from this site are chronologically and culturally heterogeneous.

${ }^{160}$ For the finds attributable to the Ljubljana culture, see e.g. Korošec 1964, Pl. 1: 3; Harej 1978, Pl. 1: 10; 2 : 8,9; 7: 6; 9: 1,2; Harej 1981-1982, Pl. 9: 9; 10: 15; 1, 11: 5; 17: 4; 18: 1; 21: 7,9-11,13-16; Harej 1987, Pl. 8: 1,3 and elsewhere.

161 For the finds that display influences of the Somogyvár-Vinkovci culture, see e.g. Korošec 1964, Pl. 1: 8; 2 : 1; 3: 1; 4: 1,2; 8: 1; 9: 9; Harej 1978, Pl. 4: 7; 10: 5; Harej 1981-1982, Pl. 8: 5; 11: 4; 12: 2; 18: 2; 22: 1; 27: 1; 30: 7; 33: 10; Harej 1987, Pl. 3: 1,3,9; 4: 12; 5: 3; 6: 5; 15: 2,4-9; 20: 7; also cf. Velušček, Čufar 2003.

162 Velušček, Čufar 2003, 128, App. 1.

163 See Založnica (Velušček, Čufar 2003, Pl. 2: 5; 3: 2; 4: 8; 8: 7; 11: 9; 13: 6; 14: 4; 15: 9; Velušček, Toškan, Čufar 2011, Pl. 2: 10); Dušanovo (= Črni Graben) (Velušček, Toškan, Čufar 2011, Pl. 3: 6,7; unpublished finds temporarily stored in the Inštitut za arheologijo ZRC SAZU). last quarter of the $25^{\text {th }}$ century BC (Fig. 8). ${ }^{164}$ The dendrochronological analyses have revealed a very brief period of construction activities for Dušanovo, taking place between 2502 and 2493 BC. ${ }^{165}$ Wood analyses of the remains at this site have provided another interesting piece of information, i.e. that the felled wood was grown by coppicing and forest thinning, which shows that people were present in the area at least several decades prior. ${ }^{166}$ This information alone does not suffice as evidence of an earlier phase of the pile-dwelling settlement, as the dendrochronological dates indicate a single short-lived phase and the recovered finds are fairly uniform. ${ }^{167}$ The dendrochronological analyses for the Špica site in Ljubljana are still being conducted, but we do have a radiocarbon date of a sample taken for the purposes of a palynological analysis. ${ }^{168}$ An acorn sample was taken from Layer SE 1004 , located under the lower cultural layer of SE $1035,{ }^{169}$ and subjected to a radiocarbon analysis that revealed a $2 \sigma$ range of $2677-2469 \mathrm{cal} \mathrm{BC}$ (at $90.5 \%$ probability). ${ }^{170}$ The dating thus offers a terminus post quem or ad quem for the construction of the pile-dwelling site at Špica, which can roughly be dated to the mid- $3^{\text {rd }}$ millennium BC. ${ }^{171}$

164 Velušček, Čufar 2003, 126, App. 1; Velušček, Toškan, Čufar 2011, 54, Fig. 3, Tab. 3; also see Čufar, Velušček, Kromer 2013. The Zal-FRSP2 chronology is not considered in this contribution as it is unsynchronised. Also found at Založnica was a horse bone radiocarbon dated to the $28^{\text {th }}$ and $27^{\text {th }}$ centuries BC. The place of this find in the context of the settlement at Založnica is as yet unclear (the find is unpublished; the archaeozoological information has been kindly provided by Borut Toškan, Inštitut za arheologijo ZRC SAZU).

165 Velušček, Toškan, Čufar 2011, 61; Kržišnik 2014, 34-35.

166 Kržišnik 2014, 47.

167 We could also be dealing with an as yet undiscovered earlier settlement in proximity.

168 Andrič et al. 2017.

169 In the publication, the sample is erroneously ascribed to the lower part of the cultural layer. A detailed inspection of the cross-section, photo archives, stratigraphic descriptions and the preliminary excavation report (Klasinc et al. 2010; kept in the ZVKDS) revealed that the analysed sample was most likely taken from Layer SE 1004 and suggests a flood prior to the construction of the pile-dwelling settlement. I wish to thank Rok Klasinc and Irena Šinkovec, who headed the excavations, for providing me with the photodocumentation and stratigraphic data.

170 Andrič et al. 2017, 484, Fig. 2; 4.

171 Three radiocarbon dates are available for Deschmann's pile-dwelling sites at Ig, two of them with a broad range of 2676-2473 cal BC $(2 \sigma ; 89.5 \%)$ OR $2620-2472$ CAL BC $(2 \sigma ; 95.4 \%)$ and most likely ascribed to Site I. If the latter is correct, the two dates are appropriate for dating the Vučedol phase at Deschmann's sites. The third date has 


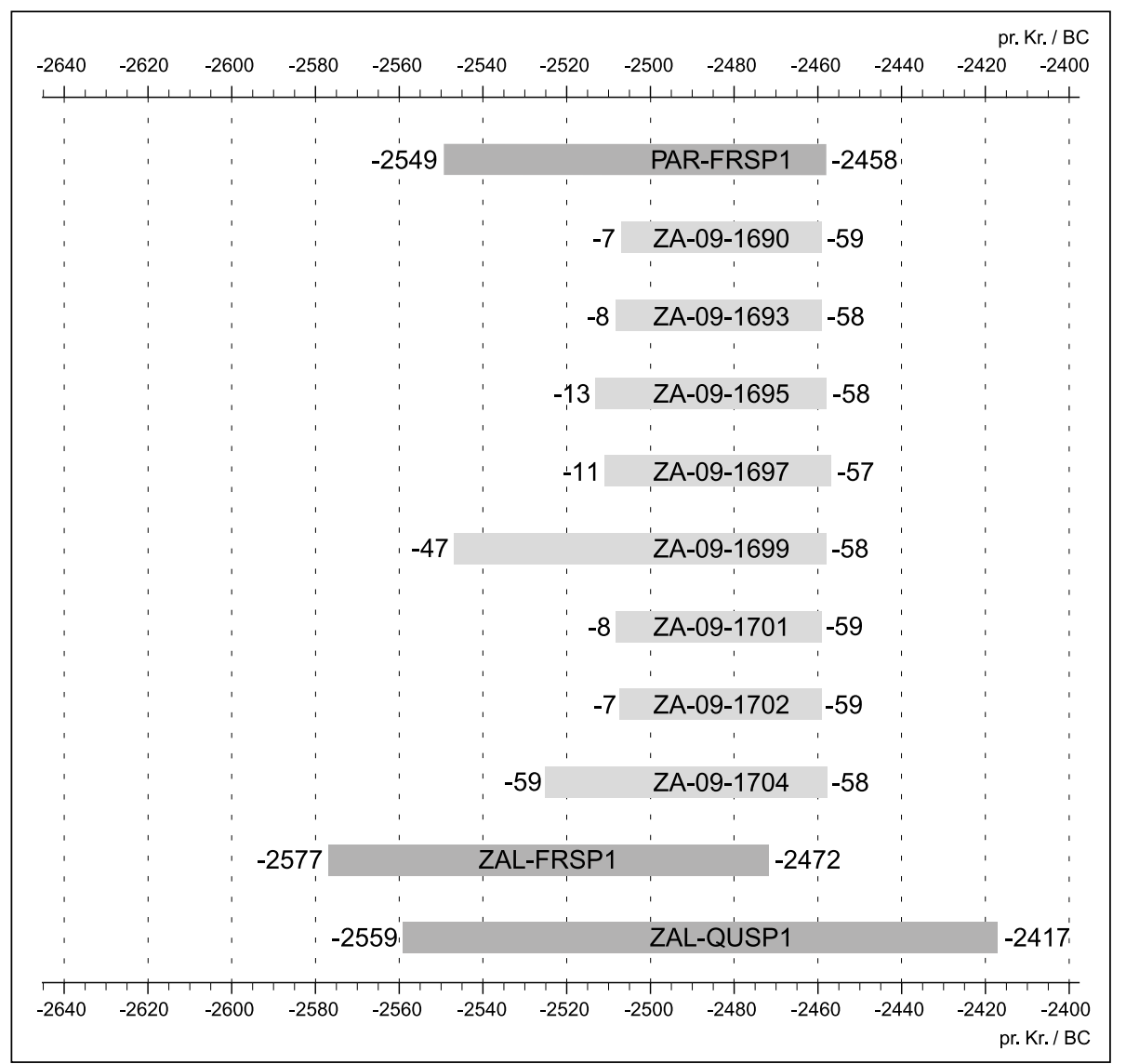

Fig. 8: Series of tree-ring widths of the dated samples from Založnica and Parte. Shown on the right are the values of the dated last tree-rings (from Velušček, Toškan, Čufar 2011, Fig. 3).

Sl. 8: Zaporedje širin branik datiranih vzorcev z najdišč Založnica in Parte. Na desni so prikazane vrednosti datiranih zadnjih branik (po Velušček, Toškan, Čufar 2011, sl. 3).

Apart from the dendrochronological dates for the sites in the Ljubljansko barje, we also have several radiocarbon dates from other sites with finds attributable to the Ljubljana culture. Two such dates come from the Adriatic cave site of Grapčeva špilja on the island of Hvar (Map 1: 38) and one from the cave of Odmut near Plužine in Montenegro (Map 1: 48). ${ }^{172}$ At Grapčeva špilja, two layers have been dated that revealed several

a range of $2620-2468$ cal BC $(2 \sigma ; 95.4 \%)$, but cannot be reliably attributed to any of the sites (see Leghissa 2017; 2018). Several radiocarbon dates are also known for the pile-dwelling site at Parte, but of a very wide range from the $29^{\text {th }}$ to the $21^{\text {st }}$ century BC (Durman, Obelić 1989). This broad range is not surprising, as the Zagreb laboratory does not provide accelerator or AMS dates, which would be more accurate. Most results of the samples analysed in this laboratory also show discrepancies that render the results unreliable (also see Črešnar, Teržan 2014a, 654 ff).

172 The dates from the tumuli in Montenegro are not taken into consideration because these tumuli are not discussed as part of the Ljubljana culture. sherds of 'Ljubljana' pottery and a coarse incised potsherd. ${ }^{173}$ In Odmut, Layer 3 was sampled that also yielded pottery mostly attributable to the Ljubljana culture. ${ }^{174}$ In addition, Pupićina peć in Istria (Map 1:28) comes with a date of Context 605 that held finds of the Ljubljana and Cetina cultures, as well as typologically earlier and later pottery. ${ }^{175}$ Three radiocarbon dates are also known from the Triestine Carso: one from Grotta dei Ciclami/Orehova pejca (Map 1:23) and two from Grotta del Mitreo/Mitrejeva jama (Map 1: 14).

The common range of these dates is very broad, encompassing the whole $3^{\text {rd }}$ millennium BC (Fig. 9). The broadest range comes from Odmut (Sample Z-409), which is $3138-2574 \mathrm{cal} \mathrm{BC}$ at $2 \sigma$ probability of $84.7 \%$. This broad range is not surprising as most samples analysed in the Zagreb laboratory

173 Forenbaher 2018a, 146.

174 Marković 1974, 8, Pl. I.

175 Hulina et al. 2011, 141, 163-164; Forenbaher 2018a, 148. 


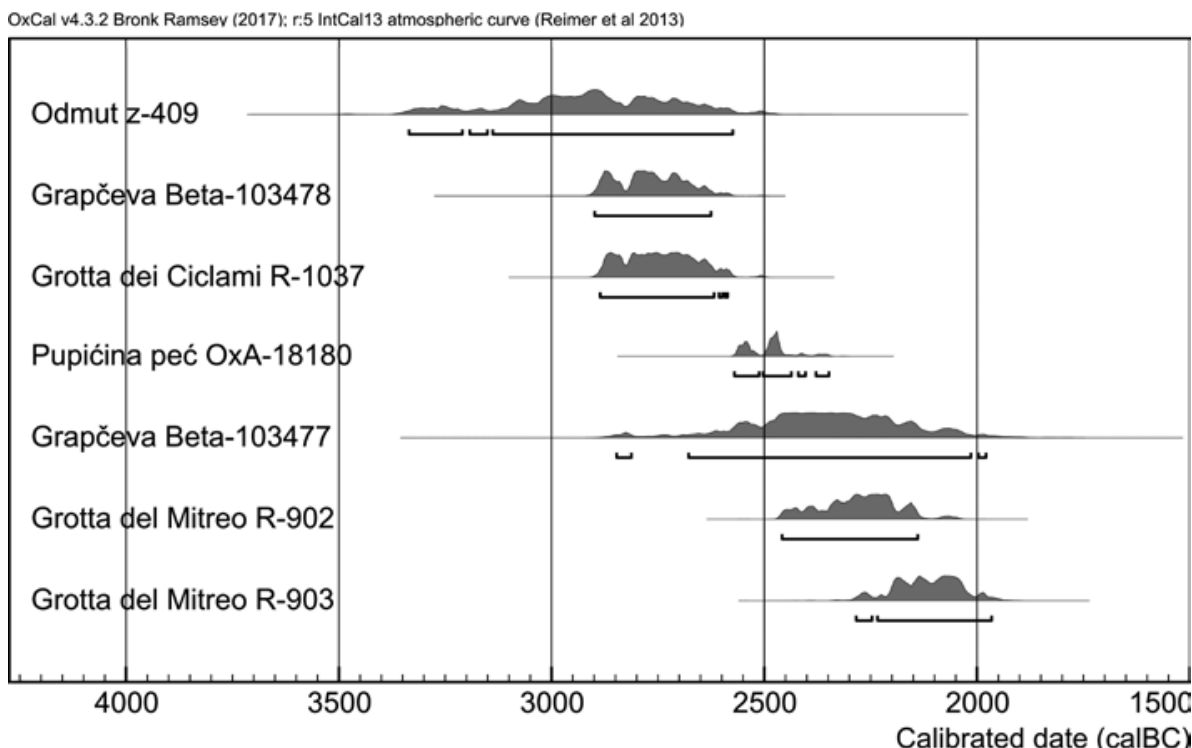

Fig. 9: Radiocarbon dates from the sites with finds of the Ljubljana culture in the Adriatic littoral: caves of Grotta dei Ciclami/ Orehova pejca and Grotta del Mitreo/Mitrejeva jama in the Triestine Carso (from Skeates 1994), cave of Pupićina peć in Istria and caves of Grapčeva špilja and Odmut in the eastern Adriatic littoral (from Forenbaher 2018a; Srdoć et al. 1977). Sl. 9: Radiokarbonske datacije $\mathrm{z}$ najdišč z najdbami ljubljanske kulture na jadranskem primorju: $\mathrm{v}$ jamah Grotta dei Ciclami/Orehova pejca in Grotta del Mitreo/Mitrejeva jama na tržaškem Krasu (po Skeates 1994), v jami Pupićina peć v Istri ter jamah Grapčeva špilja in Odmut v vzhodnojadranskem primorju (po Forenbaher 2018a; Srdoć et al. 1977).

share similarly broad ranges, which make them less useful. ${ }^{176}$ Also questionable is the veracity of the dates from Grapčeva špilja, as they pertain to four layers ascribed to the middle and peak of Phase 4 . The pottery sherds that are close to the 'Cetina style' (according to Forenbaher) lay in the earlier layers of Phase 4 and in the early layers of Phase 5, while the sherds closer to the 'LjubljanaAdriatic style' (according to Forenbaher) came to light in the later layers of Phase 4. As Forenbaher already noted, this situation suggests a likely mixed context. ${ }^{177}$ As for the dates from the Trieste Karst, they are inappropriate for dating the Ljubljana culture as they only pertain to it in broad terms - the finds from the dated contexts belong to the Vučedol, Ljubljana, Cetina and Castellieri cultures, the last one of the Middle Bronze Age. ${ }^{178}$

Compared with the dates from the cave sites of the Trieste Karst and the eastern Adriatic littoral, those for the Ljubljansko barje come from very short-lived habitation contexts and are hence much more precise. They show that the Ljubljana

176 See Črešnar, Teržan 2014a, 656.

177 Forenbaher 2018a, 140, 146; also see Forenbaher et al. 2010, 342, Fig. 6.

178 See Gilli, Montagnari Kokelj 1993; Montagnari Kokelj, Crismani 1997. culture in the Ljubljansko barje can be dated to the late $26^{\text {th }}$ and the $25^{\text {th }}$ century BC.

The hypothesis that the Ljubljana culture appeared and developed in the Ljubljansko barje is supported by a variety of arguments. The ceramic finds from Deschmann's sites include forms showing the tradition of the Vučedol phase of the pile-dwelling sites, but already decorated in the manner typical of the Ljubljana culture, i.e. with impressions of a cord whipped around a flat object; examples of these are a bowls with a cross-shaped foot, bowls on a high solid foot, high bowls and bowls with a concave neck. ${ }^{179}$ The common ware as well, which reflects influences mainly of the Somogyvár-Vinkovci culture, includes earlier forms (for example from Deschmann's pile-dwelling sites; Fig. 2: 22,26) $)^{180}$ that indicate a Vučedol tradition and a continuous development. Some vessels from the early phase at Deschmann's pile-dwelling sites already show elements of the Corded Ware culture, for example the globular two-handled vessels. ${ }^{181}$ Furthermore, the Ljubljansko barje is also the area where the

${ }^{179}$ Leghissa 2017, Pl. 86: 1-5; 98: 5; 109: 2,3; 118: 5-9 (Korošec, Korošec 1969, Pl. 33: 1-8; 37: 1; 38: 2; 56: 10,14; 113: 1,$5 ; 119: 6)$.

180 See e.g. Leghissa 2017, 138-139 (jars of Type L2), 153-155 (high bowls of Type VS1).

181 Leghissa 2017, 259-262. 
diversity of pottery types is greatest, ranging from jugs, two-handled vessels, gourd-like vessels, high bowls to different cups, which is unknown at other sites with 'Ljubljana' pottery. In my opinion, these pottery characteristics indicate an uninterrupted development from the early to the late phase of Deschmann's pile-dwelling sites.

\section{CONCLUSION}

The finds of the Ljubljana culture mark the late phase of Deschmann's pile-dwelling sites near Ig that different authors ${ }^{182}$ thus far only viewed in terms of the finer and mostly decorated pottery. The new analysis of the finds from Deschmann's sites has provided a reassessment of the characteristics pertaining to the pottery associated with this culture. The main feature of the Ljubljana culture fineware is the decoration consisting of impressions of a cord whipped around a flat object that is often combined with stabbing. The most frequent forms are globular vessels with a funnel-shaped or cylindrical neck, frequently round bases sometimes with an omphalos in the centre. The common ware is less decorated and shows similarities, possibly influences from the Somogyvár-Vinkovci and Makó-Kosihy-Čaka cultures.

It is Deschmann's pile-dwelling sites in the Ljubljansko barje that likely represent the area of origin of the Ljubljana culture. Some forms from the late phase of Deschmann's pile-dwelling sites reflect the earlier tradition of the Vučedol culture, but these 'old' forms bear the new manner of decoration (for example footed bowls). The Vučedol tradition is also visible in some of the decorative motifs, which suggests that the Ljubljana culture formed on the foundations of the Vučedol culture or its Ljubljansko barje variant and the influences/ contacts/impulses from the Corded Ware, Globular Amphora and Bell Beaker cultures. The common ware, mostly undecorated, shows similarities mainly with the Somogyvár-Vinkovci culture. This seems understandable as both the Somogyvár-Vinkovci and Ljubljana cultures formed from the Vučedol culture and continued its tradition while adopting elements from different cultures to enrich their cultural expression; each culture in its own manner. The Somogyvár-Vinkovci culture marked the Carpathian Basin, whereas the Ljubljana culture

182 E.g. Korošec 1958-1959, Dimitrijević 1967; Govedarica 1989; Forenbaher 2018a and others. represented a bridge towards the west, to the Trieste Karst and northern Italy, as well as the eastern coast of the Adriatic that also developed specific local expressions. The dendrochronological evidence, primarily from the pile-dwelling sites at Parte, which revealed numerous decorated vessels and undecorated common ware sherds, and Založnica date the Ljubljana culture in the Ljubljansko barje to the late $26^{\text {th }}$ and the $25^{\text {th }}$ century BC.

There is no pronounced eastward spread of the Ljubljana culture elements, as only three sites with such elements are known east of the Ljubljansko barje, namely Vinkovci in Slavonia (Map 1: 49), ${ }^{183}$ Hrustovača in Bosnia (Map 1: 31) $)^{184}$ and Bük in north-western Hungary (Map 1: 50). ${ }^{185}$ Even these three sites only yielded few such finds that cannot be dated with any precision, but they may indicate possible contacts with the main area of the Ljubljana culture. ${ }^{186}$ In the west, the spread of this culture can be traced to the Karst, possibly even further into northern Italy, in the west to the eastern coast of the Adriatic where such pottery mainly occurs in cave sites (Map 1). ${ }^{187}$ Dimitrijevićs

183 Dimitrijević 1982, Pl. 8: 5.

184 Benac 1948, 16-17, Tab. VI: 5; id. 1961, Pl. 32: 4.

185 Ilon 1996, 7, Pl. 1; Kiss 2012, Fig. 2: 3; also see Leghissa, Bernardini, Kiss 2018.

186 The find with the characteristic herringbone motif from Hrustovača is not mentioned in the publications by Mandić (1939) and Josip Korošec (1946). The first to publish it was Alojz Benac in 1948, who failed to give a precise findspot; it reportedly came from the same layer as other finds attributed to the Vučedol culture and the decoration was made with the use of roulette. He sees the find as evidence of influences/contacts with the Bell Beaker culture area (Benac 1948, 16-17, Tab. VI: 5). The description of the find and the published photograph show that it is similar to the bowls of Type Sk5 from Deschmann's sites. Also similar is the execution and motifs of the decoration (see e.g. Leghissa 2017, 183-184, particularly cf. Pl. 117: 8 - Korošec, Korošec 1969, Pl. 54: 2; 115: 3).

187 Map 1 only shows the most characteristic sites with the pottery of the Ljubljana culture (selection is stated in brackets for each site, common ware is not given). The last to publish a distribution map for the Ljubljana culture or the 'Ljubljana-Adriatic style' was Forenbaher (2018a, Fig. 4; and 2018b, Fig. 105), who included 80 sites with pottery more or less characteristic of the 'Ljubljana-Adriatic style' and the pottery only similar to it. He also included sites that only mention the finds of such pottery without actually being published. In my opinion, his map includes a number of sites without characteristic Ljubljana culture pottery as defined above and are therefore not considered in this contribution. The finds from some sites on the eastern Adriatic coast and in Istria, e.g. Uvala Duga on the island 
term 'Adriatic variant of the Ljubljana culture' is often used to attribute the Ljubljana culture sites in this area. ${ }^{188}$ The finds from the Karst, which are geographically closest to the Ljubljansko barje, are comparable in both form and decoration and should therefore be considered as part of the Ljubljana culture of the Ljubljansko barje ${ }^{189}$ rather than as part of its distribution area in the central and southern Adriatic. ${ }^{190}$

What remains open is the question of the relationship between the Ljubljana culture proper

of Sušac, Gudnja, Spila (Nakovana), Laganiši, are closer to the Cetina culture, particularly in the decorative manner.

188 Dimitrijević 1967.

189 In the sense of Dimitrijević's Alpine variant of the Ljubljana culture.

190 Govedarica (1989) treated them in a similar way. The differences between the Ljubljansko barje and the Karst are most apparent in the type of sites, with pile-dwelling sites in the Ljubljansko barje and caves in the Karst. and its 'Adriatic variant'. The unreliable dates for Odmut and Grapčeva špilja would suggest that the variant was earlier than the Ljubljana culture in the Ljubljansko barje. The two distribution areas - the Ljubljansko barje, the Karst and Istria, on the one hand, and central Adriatic littoral, on the other show similarities, but also apparent differences. The differences discussed in this contribution may result from the research methods and the different contexts, but may also reflect real cultural and chronological differences. We must await further research to help us solve the question of whether the appearance and particularly development of the Adriatic variant of the Ljubljana culture is connected with the spread of the influences of the Ljubljana culture from the Ljubljansko barje or took place independently in either area.

Translation: Andreja Maver

15. Grotta Teresiana/Terezijina jama (Barfield 1997-1998, Fig. / sl. 12: 46-47; 13: 49,61)

16. Grotta Fabiola (Marzolini 1969, Fig. / sl. B; Cannarella 1974, Pl. / t. 11: 1; Cannarella 2004, 89)

17. Grotta del Pettirosso/Pejca v Lašci (Leben 1967, Pl. / t. 20: 15)

18. Grotta dell'Edera/Stenašca (Marzolini 1970, Fig. / sl. 2: $5-7)$

19. Grotta Caterina/Katrna jama (Cannarella, Pitti 1978-1981, Fig. / sl. 4: 11; 5: 3-5)

20. Grotta del Pettine/ Pečinka (Marzolini 1978-1981, Fig. / sl. 1: 13,16,32)

21. Grotta degli Zingari/Ciganska jama (Gilli, Montagnari Kokelj 1996, Fig. / sl. 34: 200; 42: 299-300; 43: 312)

22. Riparo di Percedol/Prčji dol (Govedarica 1989, Pl. / t. 3:3)

23. Grotta dei Ciclami/Orehova pejca (Gilli, Montagnari Kokelj 1993, Fig. / sl. 35: 341; 37: 362; 38: 363-366; 45: 446; 47: 464-465; 50: 493-495)

24. Grotta delle Gallerie (Gilli, Montagnari Kokelj 1994, Fig. / sl. 28: 212,219,220)

25. Grotta Cotariova/Čotarjeva jama (Cannarella 19731974; Lonza 1973-1974, Fig. / sl. 2: 15,18; 3: 18; 4: 12; 5: 11; Barfield 1997-1998; Montagnari Kokelj, Greif, Presello 2002)

26. San Michele/Sv.Mihael (Nicolis 1998a, Fig. / sl. 5: 1)

27. Pećina kod Srbani (Čuka 2009, Pl. / t. 3: 13-14)

28. Pupićina peć (Miracle, Forenbaher 2006; Hulina, Forenbaher, Miracle 2011, Pl. / t. 4: 5-6)

29. Pećinovac (Okreti) (Buršić-Matijašić 2003, Pl. / t. 1. 9; 2: 13-19)

30. Vaganačka pećina (Forenbaher, Vranjican 1985, t. 5: 1-6)

31. Hrustovača (Benac 1948, 16-17, Pl. / t. VI: 5; Benac 1961, Pl. / t. 32: 4)

32. Tradanj (Benac 1961, Pl. / t. 32: 1-2) 
33. Rudine (Marović 1980, Fig. / sl. 9: 3; Marović 1991,

Fig. / sl. 32: 4,5)

34. Čitluk (Marović 1980, Fig. / sl. 8)

35. Varvara (Čović 1978, Pl. / t. 5: 2,4,5; 8: 8)

36. Otišić-Vlake (Milošević, Govedarica 1986, Pl. / t. 1: $1-5 ; 2: 1-13 ; 13: 1-8 ; 4: 1-2,6-7 ; 5: 1-3,6-7 ; 6: 1-6$;

$7: 1-3,5-6 ; 8: 1-6 ; 9: 1-4,6 ; 10: 1-4 ; 11: 1,13 ; 12: 1-2)$

37. Marina (Radović Rossi 2011, Pl. / t. 1)

38. Grapčeva špilja (Korošec 1956; Dimitrijević 1967;

Forenbaher, Kaiser 2008, Pl. / t. 20: 17-19)

39. Vela Špilja (Čečuk, Radić 1995, F. 35)

40. Ravlića pećina (Marijanović 2003, Pl. / t. 5: 1-3; 6: 1-5)
41. Ograđe (Govedarica 1989; Pl. / t. 24: 3,5-6; 26: 6)

42. Zelena Pećina (Marijanović 1978, Pl. / t. 1: 2)

43. Guvnine (Marijanović 2003, Pl. / t. 21: 1,6)

44. Badanj (Marijanović 1978, Pl. / t. 1: 1)

45. Lazaruša (Marijanović 2003, Pl. / t. 25: 5; 26: 3)

46. Hateljska pećina (Marijanović 2003, Pl. / t. 12: 3-4;

13: $4 ; 14: 3 ; 15: 1-3 ; 17: 3 ; 18: 1 ; 19: 1)$

47. Pećina Greben (Marijanović 2003, Pl. / t. 30: 1)

48. Odmut (Marković 1974; Marković 1985, Pl. / t. 29: $2-4,6,7)$

49. Vinkovci (Dimitrijević 1982, Pl. / t. 8: 5)

50. Bük (Ilon 1996, Pl. / t. 7: 1; Kiss 2012, Fig. / sl. 2: 3)

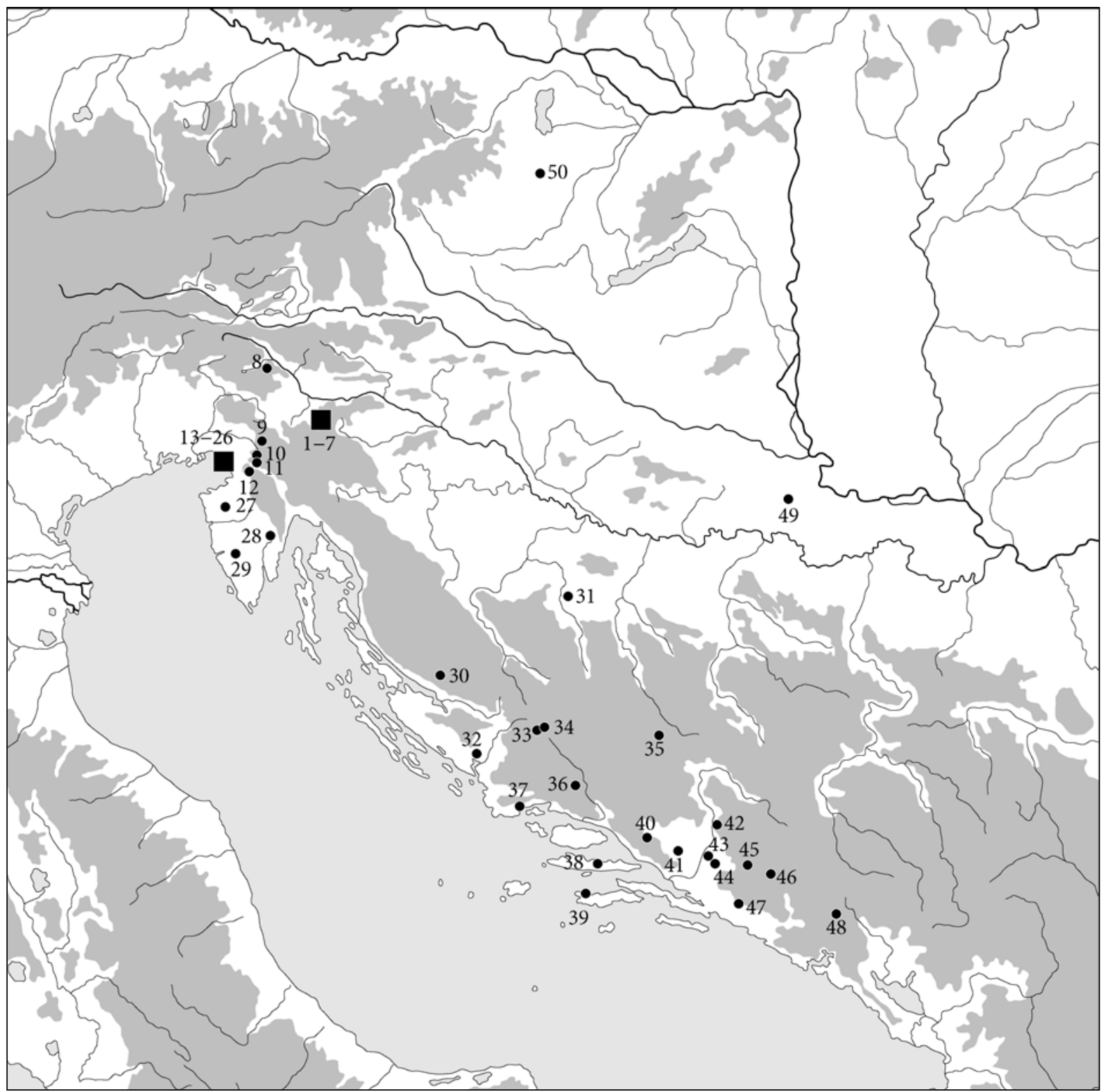

Map 1: Sites of the Ljubljana culture and its Adriatic variant, also those outside the main distribution area, with published most characteristic and mainly decorated vessels of the Ljubljana culture occurring alongside common ware (see List 1; adapted from Leghissa 2017, Fig. 181).

Karta 1: Najdišča s keramiko ljubljanske kulture in njene jadranske variante - tudi zunaj njenega matičnega območja - z objavljenimi najznačilnejšimi, večinoma okrašenimi primeri posod ljubljanske kulture, ki nastopajo ob spremni lončenini (glej seznam 1; dopolnjeno po Leghissa 2017, sl. 181). 
ANDRIČ et al. $2017=$ M. Andrič, T. Verbič, J. Lomax, T. Tolar, Človekov vpliv na okolje v prazgodovini: primer z obrežja Ljubljanice pri Špici (Ljubljana) / Embankment of the Ljubljanica River at Špica (Ljubljana) and human impact on the environment in late prehistory. - Arheološki vestnik 68, 479-498.

BAGOLINI, B., A. PASQUALI, A. PEDROTTI 1985, Monte Mezzana (Conca di Terlago). - Preistoria Alpina 21, 268-272.

BALEN, J. 2005, Sarvaš - neolitičko i eneolitičko naselje / Sarvaš - Neolithic and Eneolithic settlement. - Katalozi i monografije Arheološkog muzeja u Zagrebu 2.

BÁNDI, G. 1984, Somogyvár-gruppe. - In / V: N. Tasić (ed. / ur.), Kulturen der Frühbronzezeit das Karpatenbeckens und Nordbalkans (Kultura ranog bronzanog doba Karpatskega basena i sevrnog Balkana), Balcano-Pannonica 22, 125-132.

BARFIELD, L. H. 1997-1998, The Moser Collection in the Naturhistorisches Museum, Vienna. - Atti della Società per la Preistoria e Protostoria della regione Friuli-Venezia Giulia 11 (1999), 19-62.

BARFIELD, L. H. 2001, Beaker lithics in northern Italy. - In / V: F. Nicolis (ed. / ur.), Bell Beakers today. Pottery, people, culture, symbols in prehistoric Europe. Proceedings of the International Colloquium Riva del Garda (Trento, Italy) 11-16 May 1998, Vol. I, 507-518, Trento.

BATTAGLIA, R. 1958-1959, Preistoria del Veneto e della Venezia Giulia. - Bullettino di Paletnologia Italiana, Vol. fuori serie 67-68.

BENAC, A. 1948, Završna istraživanja u pećini Hrustovači. - Glasnik zemaljskog muzeja u Sarajevu 3, 5-41.

BENAC, A. 1961, Studien zur Stein- und Kupferzeit im nordwestlichen Balkan. - Bericht der Römisch-Germanischen Kommission 42, 1-170.

BERAN, J. 1992, A-Horizont und Kugelamphorenkultur. - In / V: M. Buchwaldek, C. Strahm (eds. / ur.), Die kontinentaleuropäischen gruppen der Kultur mit Schnurkeramik, Acta Schnurkeramik Symposium 1990, Praehistorica $19,35-41$.

BESSE, M. 2004, Bell Beaker common Ware during the third Millenium Bc in Europe. - In / V: J. Czebreszuk (ed. / ur.), Similar but different. Bell Beakers in Europa,127-148, Poznań.

BÓNA, I. 1963, The cemeteries of the Nagyrév culture. Alba Regia 2-3, 11-23.

BÓNA, I. 1965, The Peoples of Southern Origin of the Early Bronze Age in Hungary 1-2. - Alba Regia 4-5, 17-63.

BONDÁR, M. 1994, Eine frühbronzezeitliche Siedlung in Börzönce, Komitat Zala (Vorbericht). - Zalai Múzeum 5, 9-19.

BONDÁR, M. 1995, Early Bronze Age settlement patterns in South-West Transdanubia. - In / V: B. M. Szőke (ed. / ur.), Archaeology and Settlement History in the Hahót Basin SW-Hungary, Antaeus 22, 197-268.

BONDÁR, M. 2003, Kora bronzkori telep Nagykanizsa Inkey kápolnán (Frühbronzezeitliche Siedlung von Nagykanizsa - Inkey Kapelle). - Zalai Múzeum 12, 49-73.

BORGNA, E., P. CÀSSOLA GUIDA 2009, Seafarers and Land-Travellers in the Bronze Age of the Northern Adriatic. - In / V: S. Forenbaher (ed. / ur.), A Connecting Sea: Maritime Interaction in Adriatic Prehistory, BAR. International Series 2037, 89-104.
BRANIGAN, K. 1975, The round graves of Levkas reconsidered. - Annual of the British School at Athens 70, 37-49.

BUCHVALDEK, M. 1967, Die Schnurkeramik in Böhmen. - Acta Universitatis Carolinae 19.

BURŠIĆ-MATIJAŠIĆ, K. 2003, Rano naseljevanje južne Istre - Pećinovac kod Okreti (Early settling of southern Istria - Pećinovac near Okreti). - Histria Antiqua 11, 55-73.

CANNARELLA, D. 1974, Il periodo preisotorico. - In / V: Enciclopedia Monografica del Friuli-Venezia Giulia 3, La storia e la cultura, Istituto per l'Enciclopedia Monografica del Friuli venezia Giulia 3/1, 3-58, Udine.

CANNARELlA, D. 2004, Riflessioni sulla Preistoria del Carso Triestino. - Quaderni di speleologia e dellambiente carsico 3.

CANNARELLA, D., C. PITTI 1978-1981, Gli scavi nella caverna Caterina sul Carso Triestino. - Atti della Società per la Preistoria e Protostoria della regione Friuli-Venezia Giulia 4, 11-32.

CZEBRESZUK, J., M. SZMYT 2012, Bell Beakers and the cultural milieu of north European plain. - In / V: H. Fokkens, F. Nicolis (eds. / ur.): Background to Beakers. Inquiries into regional cultural backgrounds of the Bell Beaker complex, 157-175, Leiden.

ČEČUK, B., D. RADIĆ 1995, Vela Špilja. Pretpovijest otoka Korčule, katalog izložbe. - Dubrovnik 1995.

ČOVIČ, B. 1978. Velika gradina u Varvari - I dio (slojevi eneolita ranog i sredjeg bronzanog doba) (Velika Gradina im Dorf Varvara, I. Teil). - Glasnik Zemaljskog muzeja Bosne i Herzegovine u Sarajevu NS 32, 5-176.

ČREŠNAR, M., B. TERŽAN 2014a, Uvod v radiokarbonsko datiranje bronaste in železne dobe na Slovenskem / Introduction to the Radiocarbon Dating of the Bronze and Iron Ages in Slovenia. - In / V: Teržan, Črešnar 2014c, 645-660.

ČREŠNAR, M., B. TERŽAN 2014b, Absolutno datiranje bronaste dobe na Slovenskem / Absolute Dating of the Bronze Age in Slovenia. - In / V: Teržan, Črešnar 2014c, 661-702.

TERŽAN, B., M. ČREŠNAR 2014c, Absolutno datiranje bronaste in železne dobe na Slovenskem / Absolute dating of the Bronze and Iron Ages in Slovenia. - Katalogi in monografije 40.

ČUFAR, K., A. VELUŠČEK, B. KROMER 2013, Two decades of dendrochronology in the pile dwellings of the Ljubljansko barje, Slovenia. - In / V: N. Bleicher, H. Schlichtherle, P. Gassmann, N. Martinelli (eds. / ur.), DENDRO -Chronologie -Typologie -Okologie, Festschrift fur ANDRE BILLAMBOZ zum 65. Geburtstag, 35-40, Freiburg.

ČUFAR et al. $2010=$ K. Čufar, B. Kromer, T. Tolar, A. Velušček 2010, Dating of 4th millennium BC pile-dwellings on Ljubljansko barje, Slovenia. - Journal of archaeological science 37/8, 2031-2039.

ČUKA, M. 2009, Tipološka obrada odabranih ulomaka prapovijesne keramike iz pećine ispod sela Srbani / A typological analysis of selected prehistoric pottery fragments from Pećina ispod sela srbani. - Histria archaeologica 40, 13-44.

DESCHMANN, K. 1875a, Pfahlbautenfunde auf dem laibacher Morast. - Laibacher Tagblatt, 28. Juli 1875, 8 . Jahrg., Nr. 169, 3-4. 
DESCHMANN, K. 1875b, Der Pfahlbauten auf dem laibacher Moor. - Laibacher Tagblatt, 5. August 1875, 8. Jahrg., Nr. 176, 3.

DESCHMANN, K. 1875c, Die Pfahlbaufunde aus dem Laibacher Moore. - Verhandlungen der k. k. geologischen Reichsanhalt 15, 275-284.

DESCHMANN, K. 1876a, Die bisherigen Pfahlbautenfunde auf dem Laibacher Moore. - Laibacher Tagblatt, 19. Oktober 1876, 1-3.

DESCHMANN, K. 1876b, Die bisherigen Pfahlbautenfunde auf dem Laibacher Moore (Fortsetzung.). - Laibacher Tagblatt, 20. Oktober 1876, Nr. 241, 1-3.

DESCHMANN, K. 1876c, Die bisherigen Pfahlbautenfunde auf dem Laibacher Moore (Schluß). - Laibacher Tagblatt, 21. Oktober 1876. 1-2.

DESCHMANN, K. 1876d, Bericht über die Pfahlbautenaufdeckungen im Laibacher Moore im Jahre 1876. - Dezemberheft des Jahrg. 1876 d. Sitzungsberichte der Philosophisch-Historischen Klasse der Kaiserlichen Akademie der Wissenschaften 84, 471-484.

DESCHMANN, K. 1878, Ueber die vorjährigen Funde im Laibacher Pfahlbau. -Mittheilungen der Anthropologischen Gesellschaft in Wien 8 (1879), 65-82.

DESCHMANN, K. 1888, Führer durch das Krainische LandesMuseum Rudolfinum in Laibach. - Ljubljana.

DIMITRIJEVIĆ, S. 1961, Problem neolita i eneolita u sjeverozapadnoj Jugoslaviji / Problem des Neolithikums und Aeneolithikums in Nordwestjugoslawien. - Opuscula archaeologica 5, 5-78.

DIMITRIJEVIĆ, S. 1966, Rezultati arheoloških iskopavanja na področju Vinkovačkog muzeja od 1957.-1965. godine. - Acta Musei Cibalensis 1.

DIMITRIJEVIĆ, S. 1967, Die Ljubljana Kultur. Problem des Substrats, der Genese und der regionalen Typologie. Archaeologia Iugoslavica 8, 1-27.

DIMITRIJEVIĆ, S. 1979, Vučedolska kultura i vučedolski kulturni kompleks. - In / V: A. Benac (ed. / ur.), Praistorija jugoslovanskih zemalja 3. Eneolit, 267-341, Sarajevo.

DIMITRIJEVIĆ, S. 1982, Die frühe Vinkovci-Kultur und ihre Beziehungen zu Vučedoler Substrat im Lichte der Ausgrabungen in Vinkovci (1977/78) / Rana Vinkovačka kultura i njen odnos prema vučedolskemu substratu u svjetlu izkopavanja u Vinkovcima 1977.-78. godine. Opuscula archaeologica 7, 7-36.

DURMAN, A., B. OBELIĆ 1989, Radiocarbon dating of the Vučedol culture complex. -Radiocarbon 31/3, 1003-1009.

DVOŘÁK, P. 1993, Lid se zvoncovitými poháry (Glockenbecherkultur in Mähren). - In / V: V. Podborský et al., Pravěké dějiny Moravy, 218-230, 532, Brno.

ENDRÖDI, A., L. REMÉNYI (eds. / ur.) 2016, A Bell Beacker settlement in Albertfalva, Hungary (2470-1950 $B C)$. - Budapest.

FORENBAHER, S. 2013, Small but special: the island of Palagruža in the 3rd millennium BC Adriatic. - In / V: E. Starnini (ed. / ur.), Unconformist Archaeology: Papers in Honour of Paolo Biagi, BAR. International Series 2528, 89-99.

FORENBAHER, S. 2018a, Ljubljana i Cetina: lončarski stilovi 3. tisućljeća prije Krista na prostoru istočnoga Jadrana / Ljubljana and Cetina: Pottery Styles of the Third Millennium BC in the Eastern Adriatic. - Prilozi Instituta za arheologiju u Zagrebu 35, 113-157.
FORENBAHER, S. 2018b, Special Place, Interesting Times: the Island of Palagruža and Transitional Periods in Adriatic Prehistory. - Oxford.

FORENBAHER, S., T. KAISER (eds. / ur.) 2008, Grapčeva špilja Pretpovijesni stan, tor $i$ obredno mesto: rezultati arheološkog istraživanja 1996. Godine. - Split.

FORENBAHER, S., P. VRANJICAN 1985, Vaganačka pečina. - Opuscula archaeologica 10, 4-21.

FORENBAHER et al. $2010=$ S. Forenbaher, T. Kaiser, S. Frame 2010, Adriatic Neolithic Mortuary Ritual at Grapčeva Cave, Croatia. - Journal of Field Archaeology 35/4, 337-354.

FURHOLT, M. 2003, Die absolutchronologische Datierung der Schnurkeramik in Mitteleuropa und Südskaninavien. - Universitätsforschungen zur Prähistorischen Archäologie 101.

FURHOLT, M. 2008, Die Złota-Gruppe in Kleinpolen: ein Beispiel für die Transformation eines Zeichensystems? - Germania 86, 1-27.

GABROVEC, S. 1971, Stopetdeset let arheologije v Narodnem muzeju. - Argo 10, 35-48.

GILLI, E., E. MONTAGNARI KOKELJ 1993, La grotta dei Ciclami nel Carso Triestino (Materiali degli scavi 1959-1961). - Atti della Società per la Preistoria e Protostoria della Regione Friuli-Venezia Giulia 7, 65-162.

GILLI, E., E. MONTAGNARI KOKELJ 1994, La Grotta delle Gallerie nel Carso Triestino. - Atti della Società per la Preistoria e Protostoria della Regione Friuli-Venezia Giulia 8, 121-194.

GILLI, E., E. MONTAGNARI KOKELJ 1996, La Grotta degli Zingari nel Carso Triestino (Materiali degli scavi 1961-1965). - Atti della Società per la Preistoria e Protostoria della Regione Friuli-Venezia Giulia 9, 63-126.

GILLI, E., G. PETRUCCI, L. SALZANI 2000, Labitato di Bernardine di Coriano - Albaredo d'Adige (materiali degli scavi 1987-1990). - Bollettino del Museo Civico di Storia Naturale di Verona 24, Geologia Paleontologia Preistoria, 99-154.

GOVEDARICA, B. 1988-1989, O kulturnom i hronološkom položaju nalaza ljubljanske kulture na Jadranskom področju (Einiges über die kulturelle und zeitliche Stellung der Funde der Ljubljana-kultur aus dem Adriatischen gebiet). - Arheološki vestnik 39-40, (1989), 401-412.

GOVEDARICA, B. 1989, Rano bronzano doba na področju istočnog Jadrana (L'age du bronze ancien dans la region de l'Adriatique de l'est). - Djela ANUBiH 67/7.

GOVEDARICA, B. 2016, The stratigraphy of Tumulus 6 in Shtoj and the appearance of the violin idols in burial complexes of the south Adriatic region. - Godišnjak Centra za Balkanološka Ispitivanja Akademije Nauka $i$ Umjetnosti Bosne i Hercegovine 45, 5-34.

GRÖMER, K. 2010, Prähistorische Textilkunst in Mitteleuropa Geschichte des Handwerkes und Kleidung vor den Römern. - Wien.

GUŠTIN, M., A. PRELOŽNIK 2015, Gruda Boljevića - Kneževska humka kasnog bakarnog doba / Gruda Boljevića - Princely grave tumulus of the late Copper Age. - In / V: L. Saveljić-Bulatović, M. Guštin, Z. Hincak, Podgorica. Praistprijske humke i srednjovjekovne nekropole Gruda Boljevića, 15-47, Podgorica. 
GUŠTIN, M., M. ZORKO 2013, Bronastodobne in druge površinske najdbe iz Bratoncev v Prekmurju / Bronze Age and other surface finds from Bratonci in the Prekmurje region, Slovenia. - Arheološki vestnik 64, 27-63.

HAREJ, Z. 1978, Kolišče v Partih pri Igu na Ljubljanskem barju (Der Pfahlbau in Parte bei Ig auf dem Moor von Ljubljana). - Poročilo o raziskovanju neolita in eneolita v Sloveniji 6, 61-94.

HAREJ, Z. 1981-1982, Kolišče v Partih pri Igu na Ljubljanskem barju - Raziskovanja 1978. in 1979. leta (Der Pfahlbau in Parti bei Ig auf dem Moor von Ljubljana Die Forschungen im Jahren 1978 und 1979). - Poročilo o raziskovanju neolita in eneolita $v$ Sloveniji 9-10, 31-99.

HAREJ, Z. 1987, Kolišče v Partih pri Igu na Ljubljanskem barju - raziskovanja leta 1981 (Der Pfahlbau in Parti bei Ig auf dem Moor von Ljubljana - Die Forschungen im Jahr 1981). - Poročilo o raziskovanju neolita in eneolita v Sloveniji 15, 141-193.

HARRISON, R., V. HEYD 2007, The Transformation of Europe in the Third Millennium BC: the example of 'Le Petit-Chasseur I + III' (Sion, Valais, Switzerland). - Praehistorische Zeitschrift 82/2, 129-214.

HEYD, V. 2001, On the earliest Bell Beakers along the Danube. - In / V: F. Nicolis (ed. / ur.), Bell Beakers today. Pottery, people, culture, symbols in prehistoric Europe. Proceedings of the International Colloquium Riva del Garda (Trento, Italy) 11-16 May 1998, Vol. 2, 387-409, Trento.

HEYD, V. 2011, Yamnaya groups and tumuli west of the Black sea. - In / V: E. Borgna, S. Müller-Celka (eds. / ur.), Ancestral landscapes. Burial mounds in the Copper and Bronze Ages (Central and Eastern Europe - Balkans Adriatic-Aegean, $4^{\text {th }}-2^{\text {nd }}$ millennium B.C.), Travaux de la maison de l'Orient et de la Méditerranée 58, 535-555.

HOFFILLER, V. 1933, Corpus vasorum antiquorum Yougoslavie, fasc. 1. - Paris.

HULINA, M., S. FORENBAHER, P. T. MIRACLE 2011, Prapovijesna keramika iz unutrašnjeg dijela Pupićine peći (Iskopavanje 2001. godine) / Prehistoric pottery from the ineterior section of Pupićina cave (2001 excavation). - Histria Archaeologica 42, 137-184.

ILON, G. (1996): Régészeti adatok Csepreg és vidéke östörténetéhez (Archaeological data to the prehistory of Csepreg and its vicinity). - In / V: J. Dénes (ur. / ed.): Tanulmányok Csepreg történetéböl (Studies on the history of Csepreg), 6-43, Csepreg.

KERMAN, B. 2014, Pince pri Lendavi / Pince near Lendava. - In / V: Teržan, Črešnar 2014c, 31-63.

KISS, V. 2012, Central European and Southeastern Alpine Influences upon Western Trasdanubia's Early and Middle Bronze Age. - In / V: P. Anreiter et al. (eds. / ur.), Archaeological, Cultural and Linguistic Heritage, Archaeolingua 25, 321-335.

KLASINC et al. $2010=$ R. Klasinc, M. Ravnik, J. Kusetič, M. Jančar, S. Vučković 2010, Poročilo o zaščitnih arheoloških izkopavanj na najdišču Špica. - Unpublished Report / Neobjavljeno poročilo, Kranj 2010 (Zavod za varstvo kulturne dediščine Slovenije, OE Ljubljana).

KLEIJNE, J. 2019, Embracing Bell Beaker. Adopting new ideas and objects across Europe during the later 3 rd millennium BC (c. 2600-2000 BC). - Leiden.
KOROŠEC, J. 1946, Pećina Hrustovača, novi lokalitet Slavonske kulture. - Glasnik državnog muzeja u Sarajevu, NS, Društvene nauke 1.

KOROŠEC, P. 1956, Nekaj novih podatkov o slavonski kulturi na področju Jadranske obale. - Arheološki vestnik 7, 369-383.

KOROŠEC, P. 1958-1959, Kulturna opredelitev materialne kulture na koliščih pri Igu. - Arheološki vestnik 9-10, 94-107.

KOROŠEC, P. 1960-1961, Razprostranjenost slavonske kulturne grupe. - Glasnik Zemaljskog muzeja u Sarajevu 15-16 (1961), 141-150.

KOROŠEC, P. 1962, Neka pitanja oko eneolita Dalmacije. - Arheološki radovi i razprave 2, 213-238.

KOROŠEC, P. 1964, Poročilo o površinskih najdbah novega kolišča na "Partih" pri Igu. - Poročilo o raziskovanju neolita in eneolita $v$ Sloveniji 1, 47-57.

KOROŠEC, P. 1973, Eneolit Slovenije. - Arheološki vestnik 24, 167-216.

KOROŠEC, P. 1974, La fine dell'Eneolitico e l'inizio dell'età del Bronzo nelle regioni delle Alpi sudorientali. - Preistoria Alpina 10, 67-72.

KOROŠEC, P., J. KOROŠEC 1969. Najdbe s koliščarskih naselbin pri Igu na Ljubljanskem barju / Fundgut der Pfahlbausiedlungen bei Ig am Laibacher Moor. - Arheološki katalogi Slovenije 3.

KOS, J. 1978, Za stoletnico prvih arheoloških izkopavanj na Ljubljanskem barju. - Poročilo o raziskovanju neolita in eneolita v Sloveniji 6, 43-59.

KRŽIŠNIK, D. 2014, Raziskave arheološkega lesa s koliščarske naselbine Dušanovo na Ljubljanskem barju. - Master thesis / Magistrska naloga, Oddelek za lesarstvo, Biotehniška fakulteta Univerze v Ljubljani (unpublished / neobjavljeno).

KULCSÁR, G., 2009, The Beginnings of the Bronze Age in the Carpathian Basin. The Makó-Kosihy-Čaka and the Somogyvár-Vinkovci cultures in Hungary. - Varia archaeologica Hungarica 23.

KULCSÁR, G. 2013, Glimpses of the third Millennium BC in the Carpathian Basin. - In / V: A. Anders, G. Kalla, V. Kiss, G. Kulcsar, G. V. Szabo (eds. / ur.), Moments in Time. Papers Presented to Pal Raczky on His 60th Birthday, Ösregeszeti tanulmanyok / Prehistoric Studies 1, 643-659.

LEBEN, F. 1967, Stratigrafija in časovna uvrstitev jamskih najdb na Tržaškem Krasu (Stratigraphie und zeitliche Einreihung der Höhlnfundestätten auf dem Triester Karst). - Arheološki vestnik 18, 43-109.

LEGHISSA, E. 2015, Način okraševanja keramike ljubljanske kulture in pramenaste keramike - eksperimentalna arheologija / Decorating the pottery of the Ljubljana culture and the Litzen pottery - an experimental archaeology case study. - Arheološki vestnik 66, 275-292.

LEGHISSA, E. 2017, Dežmanova kolišča pri Igu in njihovo mesto v pozni bakreni in zgodnji bronasti dobi (The Dežman (Deschmann) pile dwellings near Ig in the Late Copper and Early Bronze ages). - PhD thesis / Doktorsko delo. Oddelek za arheologijo, Filozofska fakulteta Univerze v Ljubljani (unpublished / neobjavljeno).

LEGHISSA, E. 2018, Od prve fotografije do prve radiokarbonski datacije. Vučedolska koliščarska naselbina na Ljubljanskem barju (From the first photo to the first radiocarbon date. A Vučedol pile dwelling site in the 
Ljubljansko barje). - In / V: M. Črešnar, M. Vinazza (eds. / ur.) Srečanja in vplivi v raziskovanju bronaste in železne dobe na Slovenskem. Zbornik prispevkov $v$ čast Bibi Teržan, 39-52, Ljubljana. DOI: https://doi. org/10.4312/9789610600855

LEGHISSA, E., F. BERNARDINI, V. KISS 2018, Prehistoric contacts along the amber route based on non-destructive ceramic analyses. - In / V: Ž. Šmit, D. Pavlovič (eds. / ur.), Book of abstracts. $6^{\text {th }} B S A, 6^{\text {th }}$ Balkan Symposium of Archaeometry 2018, Ljubljana, Slovenija, September 25.-28., 36, Ljubljana.

LEGHISSA et al. $2020=$ E. Leghissa, Z. Kasztovszky, V. Szilágyi, I. Harsányi, A. De Min, F. Princivalle, M. Montagnari Kokelj, F. Bernardini 2020, Late-Copper-Age decorated bowls from the Trieste Karst (north-eastern Italy): what can typology, technology and non-destructive chemical analyses tell us on local vs. foreign production, exchange systems and human mobility patterns?. - Quaternary international, 20 February 2020, vol. 539, 92-104 (in print / v tisku).

LEMERCIER, O. 2004, Explorations, implantations et diffusions : le phenomene campaniforme en France mediterraneenne. - Bulletin de la Société préhistorique française 101/2, 227-238.

LEMERCIER et al. 2003 = O. Lemercier, V. Leonini, P. Tramoni, R. Furestier 2003, Campaniformes insulaires et continentaux de France et d'Italie méditerranéennes. Relations et échanges entre Corse, Sardaigne, Toscane et Midi français dans la seconde moitié du troisième millénaire avant notre ère. - In / V: Corse et Sardaigne préhistoriques, 241-251.

LONZA, B. 1973-1974, Relazione sugli scavi nella grotta Cotariova. - Atti della Società per la Preistoria e Protostoria della regione Friuli-Venezia Giulia 2, 47-68.

LOŽAR, L. 1941, Študije o Ljubljanski kulturi. - Glasnik Muzejskega društva za Slovenijo 22, 1-35.

LUTOVAC, P. 2017, Nalazi iz tumula u selu Kujava kod Danilovgrada (Finds from tumuli in the village Kujava near Danilovgrad). - Godišnjak. Centar za balkanološka ispitivanja ANUBIH 46, 55-75.

MANDIĆ, M. 1939, Prethodni isveštaj o započetom iskapanju u Hrustovačkoj pećini kod Bos. Vrpolja (Vorläufiger Bericht über die begonnene Ausgrabung der Höhle "Hrustovača bei Bos. Vrpolje (Bez. Ključ, Nordwestbosnien). - Glasnik Zemaljskog muzeja Kraljevine Jugoslavije 51(1940), 65-72.

MARAN, J. 1998, Kulturwandel auf dem griechischen Festland und den Kykladen im späten 3. Jahrtausend v. Chr. - Universitätsforschungen zur Prähistorischen Archäologie 53.

MARAN, J. 2007, Seaborne Contacts between the Agean, the Balkans and the Central Mediterranean in the $3^{\text {rd }}$ Millenium BC - The Unfolding of the Mediterranean World. - In / V: I. Galanaki, H. Tomas, Y. Galanakis, R. Laffineur (eds. / ur.), Between the Aegean and Baltic Seas: Prehistory across Borders. Proceedings of the International Conference Bronze and Early Iron Age Interconnections and Contemporary Developments between the Aegean and the Regions of the Balkan Peninsula, Central and Northern Europe, University of Zagreb, 11-14 April 2005, Aegaeum 27, 3-21.
MARIJANOVIĆ, B. 1978, Fragment eneolitske keramike iz Badnja. - Glasnik Zemaljskog muzeja Bosne i Herzegovine u Sarajevu NS 32, 177-180.

MARIJANOVIĆ, B. 1991, Ljubljanska kultura na istočnoj Jadranskoj obali. - Vjesnik za arheologiju $i$ historiju dalmatinsku 84, 215-245.

MARIJANOVIĆ, B. 2003, Eneolitik i eneolitičke kulture u Bosni i Hercegovini. - Mostar.

MARKOVIĆ, Č. 1974, The Stratigraphy and Chronology of the Odmut Cave. - Archaeologia Iugoslavica 15, 7-12.

MARKOVIĆ, Z. 1978, Rudina, Koprivnička Rijeka, Koprivnica - naselje kasne vučedolske kulture. - Arheološki pregled 20, 22-25.

MARKOVIĆ, Z. 1981, Vučedolska kultura u sjeverozapadnoj Hrvatskoj (The Vučedol Culture in North-Western Croatia). - Arheološki vestnik 32, 219-290.

MARKOVIĆ, Č. 1985, Neolit Crne Gore. - Beograd.

MAROVIĆ, I. 1980, Sinjska regija u prahistoriji (La région de Sinj dans la prehistoire). - In / V: Ž. Rapanić (ed. / ur.), Cetinska krajina od prethistorije do dolaska Turaka. Znanstveni skup, Sinj, 3-6. VI 1980, Izdanja Hrvatskog arheološkog društva $8,26-63$.

MAROVIĆ, I. 1991, Istraživanja kamenih gomila Cetinske kulture u srednjoj Dalmaciji. -Vjesnik za arheologiju $i$ historiju dalmatinsku 84, 15-214.

MARZOLINI, G. 1969, La grotta n. 1 di Visogliano. - Annali del gruppo Grotte dell'Associazione XXX Ottobre. Sezione di Trieste del Club Alpino Italiano 3, 83-88.

MARZOLINI, G., 1970, La grotta dell'Edera. - Annali del gruppo Grotte dell'Associazione XXX Ottobre. Sezione di Trieste del Club Alpino Italiano 4, 19-35.

MARZOLINI, G. 1978-1981, La Grotta del Pettine di Gabrovizza (Carso Triestino). - Atti della Società per la Preistoria e Protostoria della regione Friuli-Venezia Giulia 4, 33-43.

MENGHIN, O. 1925, Urgeschichte der bildenden Kunst in Europa. Von den Anfängen bis um 500 vor Christi. - Wien. MENGHIN, O. 1931, Weltgeschichte der Steinzeit. - Wien 1931.

MILOGLAV, I. 2016, Keramika u Arheologiji. Lončarstvo vučedolske kulture na vinkovačkom področju / Ceramics in Archaeology. Pottery of the Vučedol Culture in the Vinkovci Region. - Vinkovci, Zagreb.

MILOŠEVIĆ, A., B. GOVEDARICA 1986, Otišić, Vlake. Praistorijsko nalazište u Vrtači I. - Godišnjak. Centar za Balkanološka Ispitivanja ANUBiH 24, 51-71.

MIRACLE, P. T., S. FORENBAHER 2006, Prehistoric herders of northern Istria. The archaeology of Pupićina cave $1 /$ Pretpovijesni stočari sjeverne Istre. Arheologija Pupićine peći 1. - Arheološki muzej Istre. Monografije i katalozi 14.

MONTAGNARI KOKELJ, E., A. CRISMANI 1997, La Grotta del Mitreo nel Carso triestino. - Atti della Società per la Preistoria e Protostoria della regione Friuli-Venezia Giulia 10, 7-98.

MONTAGNARI KOKELJ, E., T. GREIF, E. PRESELLO 2002, La Grotta Cotariova nel Carso triestino (Italia nord-orinetale). Materiali ceramici degli scavi 1950-70 / The Grotta Cotoriova in the Trieste Karst (North-Eastern Italy). The pottery of the 1950-70 excavations. - Aquileia Nostra 73, 37-190.

MOTTES, E. 2001, Bell Beakers and beyond: flint daggers of northern Italy between technology and typology. - In / V: F. Nicolis (ed. / ur.), Bell Beakers today. Pottery, people, 
culture, symbols in prehistoric Europe. Proceedings of the International Colloquium Riva del Garda (Trento, Italy) 11-16 May 1998, Vol. 1, 519-545, Trento.

MOTTES, E., F. NICOLIS 1998, Aspetti culturali del bicchiere camapniforme in Trentino. - In / V: F. Nicolis, E. Mottes (eds. / ur.), Simbolo ed enigma. Il bicchiere campaniforme e l'Italia nella preistoria europea del III millenio a.C., 73-79, Trento.

MÜLLER, J. 2001, Soziokulturelle Studien zum Jung- und Spätneolithikum im Mittelelbe-Saale-Gebiet 84100-2700 v. Chr. Eine sozialhistorische Interpretation prähistorischer Quellen. - Vorgeschichtliche Forschungen 21.

MÜLLER, J. 2013, I vasi campaniforme. Il mosaico di una rete. - In / V: R. de Marinis (ed. / ur.), L'età del Rame e la pianur padana e le alpi al tempo di Ötzi, 483-502, Brescia.

NICOLIS, F. 1998a, Un nuovo aspetto ceramico tra età del rame e età del Bronzo nell'Italia settentrionale. - Rivista di Scienze Preistoriche 49, 447-468.

NICOLIS, F. 1998b, Alla periferia dell'impero: il bicchiere campaniforme nell'Italia settentrionale. - In / V: F. Nicolis, E. Mottes (eds. / ur.), Simbolo ed enigma. Il bicchiere campaniforme e l'Italia nella preistoria europea del III millenio a.C., 46-68, Trento.

PARZINGER, H. 1984, Die Stellung der Uferrandsiedlungen bei Ljubljana im äneolitischen und frühbronzezeitlichen Kultursystem der mittleren Donauländer (Mesto kolišč Ljubljanskega barja v eneolitiku in zgodnji bronasti dobi srednjega Podonavja). - Arheološki vestnik 35, 13-75.

PERINI, R. 1972, Il deposito secondario n. 3 dei Montesei di Serso. Contributo alla conoscenza del Bronzo Antico nella Regione Trentino - Alto Adige. - Preistoria Alpina, Rendiconti della Società di Cultura preistorica Tridentina 8, 7-30.

PEŠKA, J., M. KALÁBEK 2012, Prvotní informace o pohřebišti KZP s bohatými hroby z Hulína-Pravčic 2 na východní Moravě. - In / V: Sborník př́spěvků z konference Otázky neolitu a eneolitu našich zemí Vranov nad Dyjí, 29. 9.-3. 10. 2008, SBFFBU M 17, 271-282, Brno.

PITTIONI, R. 1954, Urgheschichte des Österreichischen Raumes. - Wien.

PRIMAS, M. 1996, Velika Gruda 1. Hügelgräber des frühen 3. Jahrtausends v. Chr. Im Adriagebiet - Velika Gruda, Mala Gruda und ihr Kontext. - Universitätsforschungen zur Prähistorischen Archäologie 32.

RADIĆ ROSSI, I. 2011, Problematika prapovijesnih $i$ antičkih arheoloških nalazišta u hrvatskom podmorju (Problematics of the Prehistoric and Classical Antiquity Archaeological Sites from the Croatian Undersea). - PhD thesis / Doktorska disertacija, Sveučilište u Zadru (unpublished / neobjavljeno).

RAJKOVIĆ, D., J. BALEN 2016, Sarvaš - Neolitičko i eneolitočko naslje 2 / Sarvaš -Neolithic and Eneolithic Settlement 2. - Osijek.

RUTTKAY, E. 2003, Das endneolithische Hügelgrab von Neusiedl am See, Burgenland. Zweite Vorlage - Teil II. Kulturgeschichtliche Aspekte des Zentralgrabes. - In / V: E. Jerem, P. Raczky (eds. / ur.), Morgenrot der Kulturen Frühe Etappen der Menschheitsgeschichte in Mittel- und Südosteuropa. Festschrift für Nándor Kalicz zum 75. Geburtstag, Archaeolingua 15, 445-474.
SACKEN von, E. 1876, Die Pfahlbau im Laibacher Moore. - Mittheilungen der k.k. Central-Commission 2, 24-34.

SMOLE, M. 1983, Dežmanovi zapisi o odkrivanju mostišč na Ljubljanskem barju. - Poročilo o raziskovanju neolita in eneolita $v$ Sloveniji 11, 143-170.

SRDOČ et al. 1977 = D. Srdoč, A. Sliepčević, B. Obelić, N. Horvatinčić 1977, Ruđer Bošković Institute Radiocarbon Measurements IV. - Radiocarbon 19/3, 465-475.

STACUL, G. 1971-1972, Scavo nella Grotta del Mitreo presso San Giovanni al Timavo. - Atti dei Civici musei di storia ed arte di Trieste 7, 35-60.

STACUL, G. 1976, La Grotta del Mitreo presso San Giovanni di Duino. - In / V: Studi Monfalconesi e Duinati. Atti della giornata di studio di Monfalcone 1976, Antichità Altoadriatiche 10, 29-38.

STARE, V. 1992, Arheološki depo Narodnega muzeja, Razvoj in urejevanje. - Argo 32-34, 34-41.

STRAHM, C. 1998, Il bicchiere campaniforme: fenomeno e cultura. - In / V: F. Nicolis, E. Mottes (eds. / ur.), Simbolo ed enigma. Il bicchiere campaniforme e l'Italia nella preistoria europea del III millenio a.C., 21-44, Trento.

SZMYT, M. 1996, Globular Amphora Culture in Eastern Europe. Present state of research and possibilities for future studies. - In / V: A. Kośko (ed. / ur.), Eastern exodus of the Globular Amphora culture people, Baltic-Pontic Studies 4, 3-27.

SZMYT, M. 2010, Between West and East. People of the Globular Amphora Culture in Eastern Europe: 2950-2350 BC. - Baltic-Pontic Studies 8.

ŠAVEL, I., S. SANKOVIČ 2010, Za Raščico pri Krogu I/ II. - Zbirka Arheologija na avtocestah Slovenije 13. [https://www.zvkds.si/sites/www.zvkds.si/files/uploads/ files/publication/13_za_rascico_pri_krogu.pdf].

ŠINKOVEC, I. 2014, Kolo: 5200 let / Wheel: 5200 years. Vodnik po razstavi / exibition guide. - Ljubljana.

TASIĆ, N. (ed. / ur.) 1984, Kulturen der Frühbronzezeit das Karpatenbeckens und Nordbalkans (Kultura ranog bronzanog doba Karpatskega basena i sevrnog Balkana). - Balcano-Pannonica 22.

TÓTH, K. 2001, Kora Bronzkori Településrészlet Csongrád Határában. - MFMÉ Studia Archaeologica 7, 115-160.

TRAMPUŽ OREL, N., D. J. HEATH, D. 2008, Copper finds from the Ljubljansko barje (Ljubljana Moor) - a contribution to the study of prehistoric metallurgy / Bakrene najdbe z Ljubljanskega barja - prispevek k študijam prazgodovinske metalurgije. - Arheološki vestnik 59, 17-29.

TUREK, J. 2006, Období zvoncovitých pohárů v Evropě. Archeologie ve středních Cechách 10, 275-368.

TUREK, J. 2013, Echoes and Traditions of the Bell Beaker Phenomenon. - In / V: M. Bartelheim, J. Peška, J. Turek (eds. / ur.), From Copper to Bronze Cultural and Social Transformations at the Turn of the 3rd/2nd Millennia B.C. in Central Europe, Beiträge zur Ur- und Frühgeschichte Mitteleuropas 74, 9-23.

TUREK, J. 2015, Bell Beaker stone wrist-guards as symbolic male ornament. The significance of ceremonial warfare in 3rd millennium BC central Europe. - In / V: M. Pilar Prieto Martínez, L. Salanova (eds. / ur.), The Bell beaker transition in Europe: mobility and local evolution during the $3^{\text {rd }}$ millennium $B C, 28-40$, Oxford.

TURK et al. 1992 = I. Turk, A. Bavdek, V. Perko, M. Culiberg, A. Šercelj, J. Dirjec, P. Pavlin 1992, Acijev spodmol 
pri Petrinjah, Slovenija (Die Höhle Acijev spodmol bei Petrinje, Slowenien). - Poročilo o raziskovanju neolita in eneolita $v$ Sloveniji 20, 27-48.

TURK et al. 1993 = I. Turk, Z. Modrijan, T. Prus, M. Culiberg, A. Šercelj, V. Perko, J. Dirjec, P. Pavlin 1993, Podmol pri Kastelcu - novo večplastno arheološko najdišče na Krasu, Slovenija (Podmol near Kastelec - A New Multi-layered Archaeological Site on the Karst in Slovenia). - Arheološki vestnik 44, 45-96.

VELUŠČEK, A. 2014, Absolutna kronologija slovenskega neo- in eneolitika - prispevek za razpravo / Absolute chronology of the Slovenian Neo- and Eneolithic - contribution to the discussion. - In / V: Teržan, Črešnar 2014c, 629-644.

VELUŠČEK, A. 2019, Kolišča na Ljubljanskem barju in UNESCO. - In / V: B. Djurić, B. Teržan (eds. / ur.). Arheološka dediščina Slovenije od osamosvojitve. Varovanje in prezentacija. Posvet ob evropskem letu kulturne dediščine 2018, Slovenska akademija znanosti in umetnosti, I. razred in Slovensko arheološko društvo, 22. november 2018, Ljubljana, Razprave 38.

VELUŠČEK, A., K. ČUFAR 2002, Dendrokronološke raziskav kolišč na Ljubljanskem barju - stanje 2001. Arheološki vestnik 53, 59-67.

VELUŠČEK, A., K. ČUFAR 2003, Založnica pri Kamniku pod Krimom na Ljubljanskem barju - naselbina kulture Somogyvár-Vinkovci / Založnica near Kamnik pod Krimom on the Ljubljansko barje (Ljubljana Moor) - a settlement of Somogyvár-Vinkovci Culture. - Arheološki vestnik 54, 123-158.

VELUŠČEK, A., K. ČUFAR 2014, Kolišča na Ljubljanskem barju (Pile-dwellings at Ljubljansko barje). - In / V: S. Tecco Hvala (ed. / ur.), Studia Praehistorica in Honorem Janez Dular. - Opera Instituti Archaeologici Sloveniae 30, 39-64. DOI: https://doi.org/10.3986/9789610503651
VELUŠČEK, A., K. ČUFAR, T. LEVANIČ 2000, Parte-Iščica, arheološke in dendrokronološke raziskave (Parte-Iščica, archaeological and dendrochronological investigations). - Arheološki vestnik 51, 83-107.

VELUŠČEK, A., B. TOŠKAN, K. ČUFAR 2011, Zaton kolišč na Ljubljanskem barju (The decline of pile-dwellings at Ljubljansko barje). - Arheološki vestnik 62, 51-82.

VELUŠČEK et al. 2004 = A. Velušček, K. Čufar, M. Culiberg, B. Toškan, J. Dirjec, V. Malez, F. Janžekovič, M. Govedič 2004, Črešnja pri Bistri, novoodkrito kolišče na Ljubljanskem barju (Črešnja pri Bistri, a newly discovered pile-dwelling settlement in the Ljubljansko barje). - Arheološki vestnik 55, 39-54.

VITAL, J., F. CONVERTINI, O. LEMERCIER (eds. / ur.) 2012, Composantes culturelles et premières productions céramiques du Bronze ancien dans le Sud-Est de la France. Résultats du Projet Collectif de Recherche 1999-2009. BAR. International Series 2446.

VLADÁR, J. 1962, Nagyrévske sídlisko v Čake (Nagyréver Siedlung in Čaka). - Slovenská Archeológia 10/2, 319-340.

VOLLMANN, D. 2009, Der Makó-Kosihy-Čaka-Komplex und die früheste Nagyrév-Kultur an Donau und Theiß. - In / V: V. Becker, M. Thomas, A. Wolf-Schuler (eds. / ur.), Zeiten - Kulturen - Systeme. Gedenkschrift für Jan Lichardus, 271-287, Langenweißbach.

WILLVONSEDER, K. 1940, Funde des Kreises Vučedol-Laibach in Oesterreich. - Serta Hoffileriana. Vjesnik Hrvatskog arheološkog društva NS 18-21 (1937-1940), 11-23.

WŁODARCZAK, P. 2006, Kultura Ceramiki Sznurowej na Wyżynie Małopolskiej. - Kraków.

ZAGARČANIN, M. 2016, Mogila na rake - Kneževski tumul iz ranog bronzanog doba / "Mogila na rake" - Princely tumulus from the early bronze age. - Zbornik radova Nova antička Duklja 7, 7-20.

\section{Kulturna in časovna umestitev poznobakrenodobne ljubljanske kulture na Dežmanovih koliščih pri Igu}

\section{PREGLED RAZISKAV LJUBLJANSKE KULTURE}

Izraz ljubljanska kultura (nem. Laibachkultur) je uvedel Oswald Menghin v tridesetih letih prejšnjega stoletja. ${ }^{1} \mathrm{~S}$ tem pojmom je zajel vse odkrite najdbe s kolišč na Ljubljanskem barju, ki v starejši fazi odsevajo vplive badenske kulture, v mlajši pa kulture vrvičaste keramike. ${ }^{2}$ Izraz sta v štiridesetih letih prejšnjega stoletja prevzela Kurt Willvonseder ${ }^{3}$

\footnotetext{
1 Menghin 1931.

2 Menghin 1925, 763; Menghin 1931, 54.

3 Willvonseder 1940, 30.
}

in Rajko Ložar ${ }^{4}$ za označevanje celotnega sklopa najdb s kolišč v okolici Iga, ki jih je v sedemdesetih letih 19. stoletja raziskal Dragotin Dežman (Karl Deschmann) in so v literaturi danes znana pod imenom Dežmanova kolišča (sl. 1).

Med prve obširnejše obravnave najdb z Dežmanovih kolišč sodi Ložarjeva študija o ljubljanski keramiki, ki je izšla leta 1941 v Glasniku muzejskega društva za Slovenijo. ${ }^{5}$ Ložar je v svoji študiji izpostavil predvsem podobnosti ižanskih najdb z repertoarjem najdb kulture kroglastih amfor, ki ji je

\footnotetext{
${ }^{4}$ Ložar 1941.

5 Ib.
} 
pripisal pomembno vlogo pri formiranju ljubljanske kulture. ${ }^{6} \mathrm{~V}$ petdesetih letih prejšnjega stoletja je o najdbah z Dežmanovih kolišč in njihovi kulturni pripadnosti izšla obsežna razprava izpod peresa Paole Korošec. ${ }^{7}$ Po tipoloških značilnostih keramike jih je razdelila v dve skupini, ki naj bi predstavljali dve časovni stopnji. Po njeni razdelitvi so za prvo, starejšo skupino, ki jo je poimenovala Ig I, značilne posode, kot so amfore, vrči in sklede na nogah, okrašene predvsem $\mathrm{z}$ navadnimi in brazdastimi vrezi; vzporejala pa jo je z badensko-pécelsko kulturo. ${ }^{8} \mathrm{~V}$ drugo, mlajšo skupino, poimenovano Ig II, je uvrstila skodele, posode na votlih nogah in polkroglaste sklede z odebeljenim ustjem, okrašene predvsem $\mathrm{z}$ vtisnjeno ovito nitjo in vbodi, ${ }^{9}$ in jo primerjala $\mathrm{z}$ mlajšo fazo kulture zvončastih čaš $\mathrm{v}$ Avstriji (tip Ragelsdorf-Oggau-Loretto) ter starejšo fazo unjetiške kulture; datirala pa jo je v starejšo bronasto dobo. ${ }^{10} \mathrm{~S}$ skupino Ig II je pozneje povezala tudi najdbe $\mathrm{z}$ arheoloških (jamskih) najdišč srednje Dalmacije in severnega Jadrana. ${ }^{11}$

Podobno kot Koroščeva je tudi Stojan Dimitrijević $\mathrm{v}$ šestdesetih letih razdelil najdbe $\mathrm{z}$ Iga na dve kronološki fazi. ${ }^{12}$ Starejšo (Ljubljansko barje I) je opredelil v okviru vučedolske kulture, mlajšo (Ljubljansko barje II) je pripisal ljubljanskemu faciesu licenske keramične kulture in zanjo uporabil izraz ljubljanska kultura, vendar ne v smislu Menghinove opredelitve, temveč jo je interpretiral kot rezultat spoja elementov vučedolske kulture, kulture zvončastih čaš in licenske kulture. ${ }^{13}$ Prodoru vučedolske kulture na območje Ljubljanskega barja (Ljubljansko barje I je pozneje preimenoval v stopnjo $C$ poznovučedolske kulture ${ }^{14}$ ) naj bi sledil prodor vplivov kulture zvončastih čaš, ki naj bi pripomogel k nastanku ljubljanske kulture. Ta naj bi bila sprva še sočasna $z$ vučedolsko, nato pa naj bi prevladala in se razširila vse do srednje Dalmacije, vključno s Hvarom. ${ }^{15}$ Časovno jo je vzporejal z vinkovško kulturo, ki jo je opredelil

6 Ib., 21-27, 34.

7 Korošec 1958-1959.

8 Ib., 102, 104.

9 Ib., 96, 97.

10 Ib., 99 ss, 102, 104; glej tudi Korošec 1960-1961.

11 Korošec 1962, 214 ss, 231; delitev na skupini Ig I in Ig II je P. Korošec obdržala tudi v kasnejših objavah brez bistvenih sprememb (glej npr. Korošec, Korošec 1969; Korošec 1973).

12 Dimitrijević 1961.

13 Ib., 60, 61.

14 Dimitrijević 1966.

15 Dimitrijević 1961, 63. na podlagi izkopavanj na najdišču Tržnica-Hotel v Vinkovcih. ${ }^{16}$

V okviru ljubljanske kulture je Dimitrijević ločil dva regionalna tipa: alpskega in jadranskega. ${ }^{17} \mathrm{~K}$ najdiščem alpskega tipa ljubljanske kulture je poleg Dežmanovih kolišč na Ljubljanskem barju prišteval še Linz-Scharlinz v Zgornji Avstriji, ${ }^{18}$ Vinomer pri Metliki in Hrustovačo pri Sanskem Mostu, kjer so bili najdeni posamezni fragmenti podobne keramike. ${ }^{19}$ Med značilnostmi alpske variante je navedel uporabo nazobčanega koleščka pri okraševanju posod, kar je značilno tudi za kulturo zvončastih čaš; redkeje se pojavlja vrezovanje, brazdasto vrezovanje in žigosanje. ${ }^{20}$ Jadranskemu tipu ljubljanske kulture je pripisal najdišča od tržaške obale vse do Črne gore. Med njenimi značilnostmi omenja npr. trebušaste posode s subkutanimi ušesci. $L j u$ bljansko kulturo je podobno kot vinkovško označil za postvučedolski zgodnjebronastodobni kulturni pojav, ki črpa svoje izvore $v$ vučedolski kulturi in kulturi zvončastih čaš. ${ }^{21}$

Pri objavi rezultatov izkopavanj v Vinkovcih v letih 1977-1978 je Dimitrijević vinkovško kulturo razdelil na tri razvojne stopnje. Po tej shemi je poznoklasični stopnji vučedolske kulture sledila najzgodnejša faza (Vinkovci A1), ki jo je časovno vzporejal s pozno vučedolsko fazo (stopnjo $\mathrm{C}$ vučedolske kulture).$^{22}$ Mlajšo fazo vinkovše kulture (Vinkovci A2) pa je vzporejal z ljubljansko kulturo na osnovi primerjave $\mathrm{v}$ Vinkovcih odkritega fragmenta posode s podobnimi najdbami z Dežmanovih kolišč, ki jih je pripisal t. i. alpski varianti ljubljanske kulture. ${ }^{23}$

Hermann Parzinger je najdbe s kolišč pri Igu v okviru svoje kronološke sheme kolišč Ljubljanskega barja razdelil na tri skupine ( $\operatorname{Ig} a, b$ in $\mathrm{c}$ ), ki si časovno sledijo. ${ }^{24}$ Najdbe stopnje Ig a je vzporejal predvsem s keramičnimi najdbami, značilnimi za kulture Makó-Jevišovice-Vučedol; stopnjo Ig b (ljubljansko kulturo) je opredelil v starejši del

16 Dimitrijević 1966, 34.

17 Dimitrijević 1967.

${ }^{18}$ Najdba, pripisana ljubljanski kulturi, je bolj primerljiva $\mathrm{z}$ najdbami kulture vrvičaste keramike (glej Pittioni 1954, Abb. 167: 54).

19 Dimitrijević 1967, 8 ss.

20 Ib., 10; za okras “žigosanja nazobčanega koleščka” glej Leghissa 2015.

21 Ib., 10-11.

22 Dimitrijević 1982, 15-16.

23 Ib., 18, 20.

${ }^{24}$ Parzinger 1984. Stopnjo Ig c je opredelil v čas zgodnje bronastodobne kulture s pramenasto keramiko. 
zgodnje bronaste dobe in jo primerjal s kulturami Vinkovci, Kosihy-Čaka, Hatvan, Nagyrév, Kisapostag in Nitra. ${ }^{25}$ Preučil je tudi načine okraševanja, še posebno brazdasto vrezovanje in "odtiskovanje z ovito nitjo", ki sta po Paoli in Josipu Korošcu ena od poglavitnih značilnosti za ločevanje skupin Ig I in Ig II (brazdasti vrez je značilen za Ig I, "odtiskovanje z ovito nitjo" pa za Ig II). Za Parzingerja je bilo ključnega pomena, da način odtiskovanja $z$ ovito nitjo posnema motive iz repertoarja okrasov brazdastega vreza. Na tej osnovi je sklepal, da je na Ljubljanskem barju potekal nepretrgan razvoj iz vučedolske v ljubljansko kulturo. ${ }^{26}$ Menil je, da ni upravičeno govoriti o skupinah Ig I in Ig II, temveč le o "kronoloških stopnjah", ki sta časovno zaporedni in genetično povezani. ${ }^{27}$

O ljubljanski kulturi je v osemdesetih letih izšla študija Blagoja Govedarice, v kateri obravnava zgodnjo bronasto dobo jadranskega primorja. ${ }^{28}$ Po njegovem mnenju so že v starejši fazi ižanskih kolišč (stopnja Ig I po P. Korošec) obstajale tesne povezave med Ljubljanskim barjem in Tržaškim Krasom, ki so izrazitejše v času faze Ig II. Dimitrijevićevo alpsko varianto ljubljanske kulture je preimenoval $\mathrm{v}$ klasično ljubljansko kulturo, jadransko varianto pa $\mathrm{v}$ srednjejadranski tip. ${ }^{29}$ $\mathrm{H}$ klasični ljubljanski kulturi prišteva še najdbe iz tržaških jam in $\mathrm{z}$ nekaterih najdišč $\mathrm{v}$ Istri ob jadranski obali (med njimi Vaganačko pećino) ter v severozahodni Bosni. ${ }^{30} \mathrm{Na}$ podlagi analize stratigrafskih podatkov $\mathrm{z}$ najdišč na Tržaškem Krasu (npr. Grotta del Mitreo/Mitrejeva jama, Grotta degli Zingari/Ciganska jama in Grotta Tartaruga/Želvina jama pri Briščikih) je ločil starejšo in mlajšo fazo klasične ljubljanske kulture. Klasično ljubljansko kulturo je datiral $\mathrm{v}$ čas po vučedolski kulturi in pred nastopom zgodnje bronaste dobe (oz. Bd A po Reinecku). ${ }^{31}$ Srednjejadranski tip ljubljanske kulture je glede na podobnosti $\mathrm{v}$ oblikovanju in krašenju keramičnih posod časovno vzporejal s starejšo fazo klasične ljubljanske kulture. ${ }^{32} \mathrm{~V}$ mlajšo fazo pa je, podobno kot že Dimitrijević, ${ }^{33}$ opredelil tudi najdišča na južnem Jadranu, kot so

25 Parzinger 1984, 40, 42 ss.

26 Ib., 45 ss.

27 Ib., 49 ss.

${ }^{28}$ Govedarica 1989; nekateri poudarki iz te študije so podani v Govedarica 1988-1989.

${ }^{29}$ Govedarica 1988-1989, 403; Govedarica 1989, 25 ss, 94 ss.

30 Govedarica 1989, 28-31.

31 Ib., 62.

32 Ib., 39, 94 ss, 102 ss.

${ }^{33}$ Npr. Dimitrijević 1979, 321. gomile v Rubežu, Mali Grudi in jami Odmut. ${ }^{34}$ Problematičnost njegove delitve ljubljanske kulture na dve fazi je $\mathrm{v}$ tem, da temelji na stratigrafiji tržaških jamskih najdišč, kjer je bilo ločevanje posameznih plasti zelo težavno. $V$ istih arbitrarnih odsekih namreč skupaj nastopajo najdbe, ki kažejo vplive vučedolske kulture, in najdbe, opredeljene v okvir ljubljanske, cetinske in tudi bronastodobne kaštelirske kulture. ${ }^{35}$

Novejši pogled na 3. tisočletje pr. Kr. sta prispevala Margarita Primas z objavo izkopavanj gomile Velika Gruda in revizije najdb iz gomile Mala Gruda ${ }^{36}$ ter Joseph Maran v študiji o kulturnih spremembah na grških tleh in Kikladih v poznem 3. tisočletju pr. Kr. ${ }^{37}$ Primasova je črnogorske gomile glede na radiokarbonske datume, med katerimi je eden $\mathrm{z}$ razponom $3081-2886$ cal BC $(1 \sigma),{ }^{38}$ vzporejala z zgodnjo vučedolsko fazo po Dimitrijeviću, in ne s poznovučedolskim horizontom v Podonavju in jugovzhodnoalpskem prostoru. ${ }^{39}$ Analogije za najdbe iz Velike in Male Grude je našla na Bližnjem vzhodu oz. v vzhodnem Sredozemlju ter na Balkanskem in Apeninskem polotoku. ${ }^{40}$ Maran je v okviru svoje kronološke sheme opredelil pozno vučedolsko fazo (stopnja C po Dimitrijeviću) v isti čas kot kulture Makó-Kosihy-Čaka ter zgodnjo fazo Somogyvár-Vinkovci. Ta se je obdržala še v t. i. postvučedolski čas, skupaj s skupino Csepel kulture zvončastih čaš (nem. Glockenbecher-Csepel Kultur), zgodnjo Nagyrév in ljubljansko kulturo na Ljubljanskem barju. ${ }^{41}$ Tudi po Maranu grobovi iz gomil Mala in Velika Gruda ter Boljevića Gruda pri Podgorici ne sodijo $\mathrm{v}$ čas pozne vučedolske kulture in jih ne obravnava $\mathrm{v}$ okviru ljubljanske kulture, temveč kot t. i. črnogorsko varianto vučedolske kulture. ${ }^{42}$

34 Govedarica 1989, 178, 188.

35 Glej npr. Stacul 1971-1972; Stacul 1976; Gilli, Montagnari Kokelj 1993; Gilli, Montagnari Kokelj 1994; Gilli, Montagnari Kokelj 1996; Montagnari Kokelj, Crismani 1997; Montagnari Kokelj, Greif, Presello 2002; najdbe iz tržaških jam sem si ogledala na Soprintendenza Archeologia del Friuli Venezia Giulia v Trstu. Na problematičnost Govedaričeve delitve je opozorila tudi Manuela Montagnari Kokelj s sodelavci (glej npr. Gilli, Montagnari Kokelj 1994, 158; glej tudi Forenbaher 2018a, 124).

36 Primas 1996.

37 Maran 1998.

38 Primas 1996, 48 ss, t. 4.2.

39 Ib., 165

40 Ib., 141-162.

41 Maran 1998, 314-315, 350, t. 82.

42 Ib., op. 243; Maran 2007, 8 ss; op. 36 
$\mathrm{V}$ zadnjih dveh desetletjih so $\mathrm{k}$ natančnemu datiranju koliščarskih naselbin na Ljubljanskem barju velik prispevale interdisciplinarne raziskave Antona Veluščka s sodelavci. ${ }^{43} \mathrm{~V}$ objavi najdišča Založnica pri Kamniku pod Krimom sta Velušček in Katarina Čufar keramične najdbe opredelila v okvir kulture Somogyvár-Vinkovci, ${ }^{44}$ kamor naj bi sodilo več kolišč 3 . tisočletja pr. Kr. na Ljubljanskem barju (Parte, Dušanovo $=$ Črni graben ${ }^{45}$ ter tudi del najdb z Dežmanovih kolišč $\left.{ }^{46}\right)$. Po dendrokronoloških analizah so kolišča kulture Somogyvár-Vinkovci opredeljena v 25. stoletje pr. Kr., njihov začetek pa seže že v 26. stoletje pr. $\mathrm{Kr} .{ }^{47} \mathrm{~S}$ to kulturno opredelitvijo Založnice in drugih kolišč 3. tisočletja pr. Kr. na Ljubljanskem barju je Velušček s sodelavci odprl vprašanje o upravičenosti obstoja poznovučedolske kronološke faze na Ljubljanskem barju, ki naj bi bila po Dimitrijeviću sočasna zgodnji kulturi Somogyvár-Vinkovci. Ob tem je postavil pod vprašaj tudi odnos med Somogyvár-Vinkovci in ljubljansko kulturo ter predlagal možnost, da je slednja starejša od prve. ${ }^{48}$

Med zadnje raziskave ljubljanske kulture spada študija Staša Forenbaherja, ${ }^{49}$ ki se je v svoji razpravi distanciral od tradicionalnih poimenovanj in opredeljevanj arheoloških kultur in obdobij. Zanj so osnova za opredeljevanje ljubljanske in cetinske kulture "lončarski stili". Tretje tisočletje pr. Kr. tako obravnava glede na lončarske stile in njihove časovne dimenzije. ${ }^{50}$ Alpski in jadranski tip po Dimitrijevićevu opredeljuje kot skupen ljubljansko-jadranski stil, kamor uvršča najdbe mlajše faze z Dežmanovih kolišč in podobno keramiko z Ljubljanskega barja, slovenskega in Tržaškega Krasa, dveh najdišč v severni Italiji ter vzhodnojadranske obale vse do gomil

43 Velušček, Čufar, Levanič 2000; Velušček, Čufar 2002; Velušček, Čufar 2003; Velušček et al. 2004; Velušček, Toškan, Čufar 2011, itd.

44 Velušček, Čufar 2003.

45 Poimenovanje kolišča po Velušček 2019, 73.

46 Velušček 2014; Velušček, Čufar 2014; podobno kot je že I. Bóna opozoril v šestdesetih letih prejšnjega stoletja (Bóna 1963; 1965).

${ }^{47}$ Glej npr. Velušček 2014, 638-641; Velušček, Čufar 2014, tab. 2.

48 Starejšo datacijo ljubljanske kulture v primerjavi s kulturo Somogyvár-Vinkovci naj bi nakazovala nesinhronizirana dendrokronološka krivulja ZAL-FRSP2 (Velušček, Čufar 2003, 128, 131-132; Velušček 2014, 240-241). Krivulja za zdaj ostaja nesinhronizirana in zato nezanesljiva za argumentiranje takega datiranja ter možnosti obstoja starejše faze na naselbini.

${ }^{49}$ Forenbaher 2018a; glej tudi 2018b.

${ }^{50}$ Forenbaher 2018a, 114-115. v Črni gori in Albaniji. ${ }^{51}$ Ljubljansko-jadranski stil datira glede na stratigrafske odnose, kovinske predmete in radiokarbonske datume $\mathrm{v}$ prvo polovico 3 . tisočletja pr. Kr. Na osnovi datacij črnogorskih gomil je ljubljansko-jadranski stil sočasen $\mathrm{z}$ vučedolskim, ne zgolj s poznim, temveč tudi s klasičnim. Sredi 3. tisočletja pr. Kr. pa naj bi ljubljansko-jadranskega zamenjal cetinski stil. ${ }^{52}$ Forenbaherjeva distanca do kulturnega opredeljevanja je razumljiva glede na pojmovanje arheoloških kultur v klasičnem, childovskem smislu, to je kot enovitost materialne kulture, obredov pokopavanja, naselbinskih vzorcev, prostora in časa. V tem smislu je ljubljanska kultura poseben fenomen, za katerega so značilna pretežno jamska najdišča, razširjena na jadranskem območju, čeprav je ta kultura poimenovana po koliščih na Ljubljanskem barju, ki so v naselbinskem in prostorskem smislu posebnost tega fenomena. V prispevku smo se kljub temu odločili ohraniti izraz ljubljanska kultura, s katerim želimo poudariti enovitost materialne kulture na tem območju tega kulturnega fenomena. ${ }^{53}$

\section{DEŽMANOVA KOLIŠČA IN PRIPADNOST KERAMIČNIH NAJDB POSAMEZNIM IZKOPAVALNIM ETAPAM}

Najdbe z Dežmanovih kolišč predstavljajo največji in najbolj reprezentativen sklop keramike ljubljanske kulture, zato njihova revizija odpira nov pogled na gradivo in njegovo kronološko-kulturološko mesto tako $\mathrm{v}$ ožjem kot $\mathrm{v}$ širšem okviru 3. tisočletja pr. Kr. Revizijo članka sem opravila $\mathrm{v}$ okviru doktorskega študija in na novo opredelila ljubljansko kulturo. $\mathrm{V}$ tem prispevku so povzete njene ugotovitve (Leghissa 2017). ${ }^{54}$

51 Ib., 117, 122, sl. 4; Forenbaher obravnava v okviru ljubljanske kulture tudi najdbe, ki so po mojem mnenju odraz vplivov vučedolske kulture: npr. sklede na križni in zvezdasti nogi s Tržaškega Krasa, te kažejo prvine vučedolske kulture, najverjetneje z območja Karpatske kotline (glej podrobneje Leghissa et al. 2020), in tudi najdbe iz črnogorskih gomil.

${ }^{52}$ Forenbaher 2018a, 152-153, glej tudi 2018b, 140-141.

53 Glede na široko geografsko razprostranjenost ljubljanske kulture in na očitne razlike med določenimi območji njene razprostranjenosti se je smotrno vprašati, ali je smiselno obdržati izraz ljubljanska kultura za celotno območje. Razlike, ki so lahko odraz različne "kulturološke" pripadnosti, so velikokrat pogojene tudi $z$ načinom izvedbe raziskav ter njihovim obsegom in publiciranjem.

${ }^{54} \mathrm{~V}$ pripravi je monografska objava celotnega gradiva in razprave v knjižni zbirki Katalogi in monografije Narodnega muzeja Slovenije. 
Dežmanova kolišča pri Igu so bila odkrita in raziskana $\mathrm{v}$ treh izkopavalnih etapah $\mathrm{v}$ letih 1875-1877. Dela je vodil Dragotin Dežman, kustos v Deželnem muzeju (Krainisches Landes-Museum) v Ljubljani. Na ledinah Kepje in v Partih je odkril tri koliščarske naselbine, ki so danes znane kot I., II. in III. Dežmanovo kolišče (sl. 1). Odkritje in najdbe so pritegnili pozornost širše strokovne in laične javnosti. $\mathrm{Z}$ njimi so napolnili prostore Deželnega muzeja v Ljubljani, a je veliko število najdb romalo tudi v druge muzeje in inštitucije Avstro-Ogrske ter drugam po Evropi. ${ }^{55}$ Zaradi tega doslej ni bilo mogoče izdelati popolnega seznama odkritih najdb z Dežmanovih kolišč.

Inventarizacija najdb se je v Deželnem muzeju začela konec 19. stoletja z novim muzejskim kustosom Alfonsom Müllnerjem, ki so mu bile pri tem pomembne zgolj tipološke značilnosti predmetov, zato izvornih sklopov najdb ni ohranjal in beležil skupaj. V primeru kolišč iz okolice Iga je najdbe iz posameznih etap izkopavanj združil, tako da se je sled za izvorno lokacijo in konteksti zabrisala. A naj bi najdbe po tipih združeval že Dežman. ${ }^{56}$ Tako se je izgubil pomemben podatek o njihovi pripadnosti posameznim izkopavalnim fazam in posamezni koliščarski naselbini.

Namen ponovne revizije in preučevanja najdb z Dežmanovih kolišč je bil med drugim ugotoviti, kdaj so bile najdbe odkrite in kateremu kolišču so pripadale. $S$ preučevanjem različnih Dežmanovih poročil in zapisov ter časopisnih člankov in notic, pa tudi poročila Eduarda von Sackna ${ }^{57}$ ter Dežmanovih zapisanih letnic in oznak na nekaterih posodah, odkritih leta 1877 na območju II. kolišča, je bilo za precejšnje število posod mogoče ugotoviti, s katerega kolišča izvirajo. ${ }^{58}$

I. Dežmanovemu kolišču lahko pripišemo predvsem najdbe, opredeljene v okvir vučedolske kulture; to so npr. bogato okrašeni bikonični in kroglasti vrči, kroglaste dvoročajne posode in njihovi fragmenti, okrašeni s krožnimi motivi, ter sklede na

\footnotetext{
${ }^{55}$ Več najdb hrani Naturhistorisches Museum na Dunaju; ostale institucije, ki hranijo oz. so jim podarili najdbe z Dežmanovih izkopavanj v letih 1875-1877, so Museum der Sternwarte Kremsmünster v Zgornji Avstriji, zbirka M. Much na Dunaju, Universalmuseum Joanneum v Gradcu v Avstriji, Antropološko društvo (Anthropologische Gesellschaft) v Kölnu in Museo di antropologia dell'Università di Padova in še bi lahko naštevali.

56 Gabrovec 1971, 40; Stare 1992, 35.

57 Glej npr. Deschmann 1875a-c; 1876a-d; 1878; 1888; glej še von Sacken 1876; Kos 1978 in Smole 1983.

58 Glej podrobneje Leghissa 2017, 58-79.
}

križnih nogah z okrasom na notranji in zunanji površini. I. Dežmanovo kolišče lahko opredelimo kot vučedolsko naselbino, ki je bila glede na radiokarbonsko datiranje poseljena verjetno vsaj že konec 27. st. pr. Kr. in v 26. stoletju pr. Kr..$^{59}$ Najdbe te faze smo opredelili kot Ljubljansko barjansko varianto vučedolske kulture. ${ }^{60}$

II. Dežmanovo kolišče je bilo po Dežmanovemu pričevanju drugačno od prvega: koli na njem so bili tesneje postavljeni in močnejši. Poimenoval ga je Hauptpfahlbau (glavno kolišče). Okras na keramičnih posodah in fragmentih je bil izdelan $\mathrm{z}$ večjo natančnostjo, večinoma $\mathrm{z}$ odtiskovanjem niti (nem. schnurförmigen Eindrücke). ${ }^{61}$ Novost, ki se pojavlja na keramičnih posodah s tega kolišča, so subkutana ušesca. ${ }^{62}$ Med izstopajoče najdbe sodijo figuralne posode, keramični kalupi za ulivanje uhatih in ploščatih sekir, keramične talilne posode ter bakrene najdbe. Poleg okrasa $\mathrm{z}$ odtisi niti, navitih na ploščice, se na posodah pojavlja tudi okras $\mathrm{z}$ odtisi prsta in nohta, metličenje in glavničenje, nekaj fragmentov loncev ima odebeljen in okrašen rob. Temu kolišču lahko pripišemo tudi nekaj okrašenih fragmentov skled na nogah. II. Dežmanovo kolišče je najverjetneje nastalo že $\mathrm{v}$ času ljubljanske barjanske variante vučedolske kulture. Brez odgovora pa ostaja vprašanje, ali je njegova poselitev deloma sovpadala s poselitvijo I. kolišča. Življenje na njem se je nadaljevalo in razcvetelo v t. i. mlajši fazi Dežmanovih kolišč, ki je opredeljena kot ljubljanska kultura.

Precej težje je bilo identificirati najdbe III. Dežmanovega kolišča, kajti na njem so izkopavali le nekaj dni v predzadnjem tednu izkopavanj leta 1877. Dežman je poročal, da so bile najdbe maloštevilne, bolj grobe in $\mathrm{z}$ debelejšimi stenami. ${ }^{63}$ III. Dežmanovo kolišče je treba obravnavati skupaj s koliščema Parte in Parte-Iščica (sl. 1), ki ležita v njegovi neposredni bližini. ${ }^{64}$ Kolišče Parte, raziskano v letih 1976-1981, leži na parcelah št. 1424-1426, približno $60 \mathrm{~m}$ južneje od III. Dežmanovega kolišča. ${ }^{65}$ Parte-Iščica, raziskano v letih 1997-1998, leži v strugi Iščice ob robu parcel 1421-1431, približno 85 m vzhodno od III. Dežmanovega kolišča. ${ }^{66}$

59 Leghissa 2018, 46.

${ }^{60}$ Leghissa 2017, 275, 278-280.

61 Gre za okras odtisov niti, navitih na ploščate predmete (Leghissa 2015).

62 Deschmann 1876d, 478; Kos 1978, 55-56.

63 Smole 1983, 155-156.

64 Glej že Velušček, Čufar, Levanič 2000, 83.

65 Harej 1978; 1981-1982; 1987.

66 Velušček, Čufar, Levanič 2000. 
Vse tri lokacije pokrivajo areal približno 1,5 ha, na katerem sta bili na podlagi dendrokronoloških analiz prepoznani vsaj dve naselbini: starejša na vzhodu na območju današnje reke Iščice, datirana $\mathrm{v} 28$. in 27. st. pr. Kr., in mlajša na zahodu na območju Harejevih izkopavanj, verjetno je bila po krajši prekinitvi poseljena od konca 26. in v 25. st. pr. Kr. ${ }^{67} \mathrm{~S}$ sondama, izkopanima v letu 1877 , je bil najverjetneje odkrit skrajni severni rob zahodne naselbine - kolišča Parte.

\section{NAJDBE MLAJŠE FAZE \\ DEŽMANOVIH KOLIŠČ IN OPREDELITEV LJUBLJANSKE KULTURE}

Glede na revizijo keramičnih najdb z Dežmanovih kolišč pri Igu, rezultate ugotavljanja pripadnosti posameznim izkopavalnim etapam in nove tipološko-kronološke analize ${ }^{68}$ je mogoče prepoznati tri glavne skupine. Prvi sklop keramičnih najdb odseva značilnosti vučedolske kulture in tudi vplive/ stike $\mathrm{z}$ drugimi sočasnimi kulturami, npr. kulturo vrvičaste keramike, kulturo Jevišovice in zgodnjo fazo kulture Makó-Kosihy-Čaka. ${ }^{69}$ Pripisujemo ga najstarejši fazi poselitve Dežmanovih kolišč (faza I).

Drugi sklop predstavljajo najdbe, ki so jih že različni avtorji ${ }^{70}$ opredelili v mlajšo fazo poselitve Dežmanovih kolišč oz. v ljubljansko kulturo po Dimitrijeviću $^{71}$ (sl. 2: 1-19). Med poglavitnimi značilnostmi je okras, izveden z odtiskovanjem niti, navite na ploščat predmet. K tretjemu sklopu prištevamo najdbe, ki odražajo vplive predvsem kultur Somogyvár-Vinkovci in Makó-Kosihy-Čaka, razprostranjenih v Karpatski kotlini (sl. 2: $20-23,25-31) .{ }^{72} \mathrm{Za}$ večino najdb drugega in tretjega sklopa smo lahko ugotovili njihovo pripadnost II. Dežmanovemu kolišču. Drugi in tretji sklop najdb sta bila označena za mlajšo fazo Dežmanovih kolišč.

Najznačilnejše oblike posod mlajše faze Dežmanovih kolišč po tipologiji Leghissa (2017) so:

- kroglasti vrči in vrčki z lijakastimi vratovi tipa V4 (sl. 2: 1,2,5);

67 Velušček, Čufar, Levanič 2000, 99.

68 Tipologija ter kronološka in kulturna opredelitev najdb sta $\mathrm{v}$ nadaljevanju povzeti po Leghissa 2017.

${ }^{69}$ Za podrobnejšo utemeljitev glej Leghissa 2017, 278-280.

70 Glej Korošec 1958-1959; Dimitrijević 1967; 1979; Parzinger 1984; Govedarica 1989.

71 Dimitrijević 1967; 1979.

72 Glej npr. Bondár 1995; Velušček, Čufar 2003; Kulcsár 2009.
- kroglaste dvoročajne posode z lijakastimi ali cilindričnimi vratovi ter subkutanima ušescema tipa DvP4b (sl. 2: 3,4,9);

- bučaste posode sploščeno kroglaste oblike, ki imajo lijakaste vratove (tip B1), lahko pa tudi subkutana ušesca ali navpično predrta držaja (tip B2) (sl. 2: 7,8);

- visoke kroglaste sklede z lijakastimi vratovi tipa Vs2 (sl. 2: 14);

- visoke sklede $\mathrm{z}$ visokim konkavno usločenim vratom tipa Vs3, na katerem sta lahko subkutani ušesci (sl. 2: 12);

- polkroglaste sklede z ravnim odebeljenim ustjem tipa S1 (sl. 2: 16);

- sklede na votlih koničnih nogah tipa SnN9 (sl.

2: 18,19);

- kroglaste skodele z lijakastimi vratovi tipa Sk5 (sl. 2: 15);

- skodele s konkavno usločenim vratom in ostrim prehodom v polkrožno oblikovan spodnji del posode tipa Sk6 (sl. 2: 13).

Ostale oblike keramičnih posod druge skupine so: - bikonični in kroglasti neokrašeni vrči in vrčki tipa V1a, V2a in V2c (sl. 2: 20,21);

- neokrašene kroglaste in bikonične dvoročajne posode tipa DvP1 in DvP2;

- trebušaste dvoročajne posode iz drobno- oziroma grobozrnate gline; ${ }^{73}$

- enoročajni lonci, okrašeni z bradavicami na ramenu L2 (sl. 2: 26); ${ }^{74}$

- enoročajni ovalni lonci s cilindričnim vratom tipa L3;

- kroglasti ali ovalni lonci z lijakastimi vratovi tipa L5 (sl. 2: 27);

- ovalne dvoročajne shrambne posode tipa Sp1 (sl. 2: 29);

- posode $\mathrm{z}$ odebeljenim robom ustja, okrašenim z odtisi prsta oz. prsta/nohta tipa Sp2 (sl. 2: 30);

- večinoma neokrašene visoke sklede tipa Vsla in Vs1b (sl. 2: 22);

- konične sklede tipa S2 (sl. 2: 23);

- polkroglaste skodele tipa Sk1 (sl. 2: 25);

- konične skodele tipa Sk2;

- kroglaste in sploščeno kroglaste skodele tipa Sk3;

- bikonične skodele z lijakastimi vratovi tipa Sk4.

Posamezni keramični tipi druge oz. mlajše skupine predstavljajo le blago spremenjene stare

${ }^{73}$ Leghissa 2017, t. 41: 1-3 (Korošec, Korošec 1969, t. 7: 2; 12: 1; neinventarizirana najdba, hrani NMS).

${ }^{74}$ Leghissa 2017, npr. t. 58: 3; 59: 1-5; 60: 3 (Korošec, Korošec 1969, t. 12: 6; 16: 4; 21: 2; 26: 5; 27: 1,3; 62:9). 
oblike, značilne za prvi sklop, to je za starejšo fazo na Dežmanovih koliščih. Taki so npr. vrči z bikonično ali kroglasto oblikovanim trupom tipa V1a in $\mathrm{V} 2 \mathrm{a}$, dvoročajne posode $\mathrm{s}$ kroglastim trupom tipa DvP1, neokrašeni lonci z ovalnim trupom in usločenim vratom tipa L2 ter visoke sklede $\mathrm{z}$ izvihanim ustjem in sploščenim trupom tipa Vs1. Med njimi so tudi sklede na križnih ali v tlorisu krožnih nogah, okrašene s preprostejšimi motivi, večinoma le na notranji površini in na robu ustja, ki jih razlagamo kot prežitke vučedolske kulture (npr. sl. 2: 24,28,31).

Ključna novost mlajše faze Dežmanovih kolišč pa je predvsem krašenje posod $\mathrm{z}$ vtiskovanjem na ploščat predmet navite niti. Okras je pogosto dopolnjen $\mathrm{z}$ vtiskovanjem predmeta $\mathrm{z}$ ostro ali topo konico. Tako okrašene posode predstavljajo najznačilnejši repertoar ljubljanske kulture. $\mathrm{Na}$ tak način je okrašenih tudi nekaj skled na nogah, oblikovno vezanih na tradicijo vučedolske kulture, med njimi npr. skleda na križni nogi (sl. 2: 24) in dve na visoki polni krožni nogi. ${ }^{75}$ Take sklede združujejo za vučedolsko kulturo značilno obliko in za ljubljansko kulturo značilen okras, zato jih lahko razlagamo kot pokazatelje nepretrganega razvoja med starejšo in mlajšo fazo na Dežmanovih koliščih (sl. 3: prim. 9-10 z 11-12).

Navezavo na vučedolsko kulturo odsevajo tudi druge vrste lončenine mlajše faze Dežmanovih kolišč (sl. 3). Taki so npr. bikonični in kroglasti, večinoma neokrašeni vrči tipa V1 in V2 (sl. 3: prim. 3-4 z 1-2), enoročajni ovalni lonci z bradavicami na ramenu (sl. 3: prim. 19 s $17-18)^{76}$ ter visoke sklede in skodele s konkavno usločenim vratom tipa Vs3 in Sk6, ${ }^{77}$ ki so oblikovno podobne skodelam s trakastim ročajem v vučedolski kulturi (sl. 3: prim. 7-8 s 5-6). ${ }^{78}$ Vučedolsko tradicijo prepoznamo tudi v motiviki okrasa posod ljubljanske kulture, kot so nasproti si stoječi šrafirani trikotniki in motiv valovnice, ki je sestavljena iz dveh vzporednih vtisnjenih/vrezanih linij, pri čemer je bil

75 Leghissa 2017, t. 98: 5; 109: 2,3 (Korošec, Korošec 1969, t. 37: 1; 38: 2; 41:7; 113:5).

76 Glej npr. Leghissa 2017, t. 59: 1-5; 60: 1-4 (Korošec, Korošec 1969, t. 12: 5,6; 21: 2; 23: 11; 24: 8; 26: 5; 27: 1,$3 ; 62: 9$ ).

77 Npr. Leghissa 2017, t. 86: 1-5 (Korošec, Korošec 1969, t. 33: 4,6,7; 56: 10V 14).

78 Takih posod na Dežmanovih koliščih ni bilo, so pa razširjene na hrvaških najdiščih vučedolske kulture: glej npr. Dimitrijević 1979, 287, 290 ss, sl. 10: 11,15-17, npr. t. $27: 2 ; 29: 1,5 ; 30: 9$. osrednji greben razčlenjen $\mathrm{z}$ izmeničnimi vbodi (sl. 3: prim. $20 \mathrm{z} 21$ in $22 \mathrm{~s} 23-25$ ).

Nekatere oblike posodja ljubljanske kulture odsevajo elemente, ki se navezujejo na tradicijo srednjeevropskih kultur vrvičaste keramike ${ }^{79}$ in kroglastih amfor, ${ }^{80}$ datiranih okvirno v prvo polovico 3. tisočletja pr. $\mathrm{Kr}^{81}$ Take so npr. kroglaste dvoročajne posode s cilindričnimi ali lijakastimi vratovi tipa DvP4 (sl. 4), ki so razprostranjene na slovenskem in Tržaškem Krasu ${ }^{82}$ ter v vzhodnojadranskem prostoru (sl. 4: 3,5-6). ${ }^{83}$ Podobno okrašene fragmente posod zasledimo na območju severne Italije, zlasti na najdiščih kulture zvončastih čaš. ${ }^{84}$ Njihov izvor kaže iskati na območju kultur kroglastih amfor in/ali vrvičaste keramike, kjer med značilne oblike spadajo kroglaste posode s praviloma cilindričnimi vratovi in štirimi ali dvema ročajema oziroma tunelastima držajema, podobnost med njimi in primerki z Dežmanovih kolišč pa je očitna (sl. 4: 7-10). ${ }^{85}$

Različni raziskovalci so v okviru najdb ljubljanske kulture opozorili tudi na elemente, ki odsevajo možne "stike" s kulturo zvončastih

${ }^{79}$ Nem. Schnurkeramik Kultur, angl. Corded Ware culture.

${ }^{80}$ Nem. Kugelamphoren-Kultur, angl. Globular Amphora Culture.

81 Glej npr. Szmyt 1996, 3 ss; Müller 2001, 210, 222, sl. 101; 102; Furholt 2003; 2008; Szmyt 2010, 7 ss, 52 ss; vplivi kulture vrvičaste keramike so opazni že v starejši fazi Dežmanovih kolišč, tj. v fazi ljubljanskobarjanske variante vučedolske kulture po Leghissa (2017, 259-261).

82 Glej npr. Tomičeva jama pri Škocjanu - karta 1: 9 (Battaglia 1958-1959, 396, 397, sl. 152); Podmol pri Kastelcu - karta 1: 11 (Turk et al. 1993, t. 14: 15; 16: 5,15-17); Grotta del Mitreo/Mitrejeva jama - karta 1: 14 (Montagnari Kokelj, Crismani 1997, sl. 13: 109; 31: 278); Grotta Cotariova/Čotarjeva jama - karta 1: 25 (Lonza 1973-1974, sl. 2: 18; 3: 16; 5: 12); Grotta Caterina/Katrna jama - karta 1: 19 (Cannarella, Pitti 1978-1981, sl. 5: 3-5).

${ }^{83}$ Glej npr. Pećina kod Srbani - karta 1: 27 (Čuka 2009, t. 3: 13); Otišić-Vlake - karta 1: 36 (Milošević, Govedarica 1986, t. $1: 1 ; 2: 5-9 ; 3: 1,7 ; 4: 6 ; 6: 4)$; Marina blizu Splita karta 1: 37 (Radić Rossi 2011, 117-118, t. 1: 1-2); Čitluk - karta 1: 34 (Marović 1980, 34, sl. 8); Odmut - karta 1: 48 (Marković 1974, 9, t. 4: 1,2,7,9; Marković 1985, t. 29: 2,3,6,7); Zelena pećina južno od Mostarja - karta 1: 42 (Marijanović 1978, t. 1: 2); Badanj v bližini naselja Borojevići pri Stolcu v Hercegovini - karta 1: 44 (Marijanović 1978, 177 ss, t. 1: 1).

${ }^{84}$ Npr. Nicolis 1998a, sl. 1: 1,2; 2: 1-16 (večinoma gre za fragmente posod, zato oblik ni mogoče ugotoviti, vendar so zastopani tudi cilindrični, blago lijakasti vratovi); glej tudi Gilli, Petrucci, Salzani 2000, 126, t. V: 13.

${ }^{85}$ Glej npr. Buchvaldek 1967, sl. 2: A20,A21; 3: A25b; Beran 1992, sl. 3; Włodarczak 2006, 121 ss, t. 14; 23: 4; Furholt 2003, 131 ss; Furholt 2008, 11 ss, sl. 8; 9. 
čaš. ${ }^{86}$ Ti se kažejo v lijakasti obliki vratov, npr. pri vrčih tipa V4, dvoročajnih posodah tipa DvP4b in bučah tipov B1 in B2 (sl. 2: 1-3,7-9), ter $\mathrm{v}$ razporeditvi po pasovih okrasnih motivov, sestavljenih iz preprostih trikotnikov, cikcak črt ali mrežastih motivov. ${ }^{87}$ Obe kulturi poznata tudi podoben način okraševanja, in sicer odtiskovanje na ploščat predmet navite niti. Tak način krašenja je v okviru kulture zvončastih čaš znan kot okras barbelé (fr.) oz. Barbed-wire (angl.). ${ }^{88}$ Lončenina $\mathrm{z}$ okrasom barbelé je genetsko povezana s fenomenom kulture zvončastih čaš in je opredeljena na prehod iz pozne bakrene $\mathrm{v}$ zgodnjo bronasto dobo. Pogosta je predvsem v severni Italiji in jugovzhodni Franciji, kjer označuje zaključno fazo kulture zvončastih čaš, t. i. Épicampaniforme, datirano v časovni okvir ok. $2150-1900$ pr. $\mathrm{Kr}^{89}$ Po mnenju Franca Nicolisa ${ }^{90}$ in drugih raziskoval$\operatorname{cev}^{91}$ je na tak način krašenja keramike $\mathrm{v}$ severni Italiji in v jugovzhodni Franciji verjetno vplivala ljubljanska kultura Ljubljanskega barja. ${ }^{92} \mathrm{Za}$ območje severne Italije je hipoteza težko preverljiva zaradi številčne skromnosti tako okrašene keramike, z izjemo najdišča Bernardine di Coriano. $\mathrm{Na}$ tem je bilo najdenih pribl. 40 različno velikih fragmentov tovrstne lončenine; nekatere oblike lahko nedvomno povežemo s kulturo zvončastih čaš, ${ }^{93}$ nekatere druge so podobne tistim ljubljanske kulture. ${ }^{94} \mathrm{Za}$ natančnejše datiranje keramike barbelé $\mathrm{v}$ severni Italiji radiokarbonske datacije niso na voljo. Na splošno označuje lončenina $\mathrm{z}$ okrasom barbelé najmlajšo fazo kulture zvončastih čaš, kar je $\mathrm{v}$ absolutnem smislu skoraj 400

${ }^{86}$ Npr. Korošec 1958-1959, 99; Dimitrijević 1967, 10 ss; Gilli, Montagnari Kokelj 1993, 158; itd.

${ }^{87}$ Glej npr. Leghissa 2017, t. 32: 2; 43: 1; 44: 3-4; 45: 1-2; 47: 6; 84: 3-4; 85: 3-9 itd. (Korošec, Korošec 1969, t. $34: 2-4 ; 35: 8,9 ; 36: 1 ; 49: 12 ; 54: 10 ; 55: 1,3 ; 56: 1,5,8,15$; 57: 12; 60: 4; 115: 1,4; 116: 2,5; 118: 6,9).

${ }^{88}$ It. a filo avvolto ali filo spinato.

${ }^{89}$ Glej npr. Nicolis 1998a, 447-464, sl. 1: 1-2; 2: 21-16; Nicolis 1998b, 57; Strahm 1998, 40; Gilli, Petrucci, Salzani 2000, 125-126; Lemercier et al. 2003, 248-249; Lemercier 2004, 228, sl. 1; Vital, Convertini, Lemercier 2012, 1 ss, 91 ss, 97 ss, 109. Tako okrašena keramika je razširjena tudi na severnih območjih srednje Evrope in jugovzhodne Anglije, kjer je prav tako značilna za zaključno fazo kulture zvončastih čaš (glej npr. Nicolis 1998a, 449; Czebreszuk, Szmyt 2012, 166, sl. 11).

${ }^{90}$ Nicolis 1998a, 455 ss.

91 Npr. Lemercier et al. 2003, 243, 248-249.

92 Nicolis 1998a, 455 ss.

${ }^{93}$ Npr. Gilli, Petrucci, Salzani 2000, t. IV: 1,3,5.

94 Ib., t. IV: 6; V: 13. let pozneje od časovne umestitve najdišč v okvir ljubljanske kulture na Ljubljanskem barju. Iz tega izvira velik pomislek, ali je območje Ljubljanskega barja z ljubljansko kulturo sploh kakorkoli vplivalo na pojav tovrstnega okrasa $\mathrm{v}$ severni Italiji in južni Franciji.

Z območja II. Dežmanovega kolišča izvira tudi edina posoda hruškaste oblike, ki po okrasu spominja na zvončaste čaše (sl. $5: 1)$, medtem ko se po obliki razlikuje od klasičnih zvončastih čaš, ki imajo praviloma izvihano ustje. ${ }^{95}$ Njen okras je sestavljen iz petih vodoravnih pasov vrezanih linij in vbodov in je primerljiv $\mathrm{z}$ nekaterimi vrstami okrasa na značilnem posodju kulture zvončastih čaš (it. set campaniforme; angl. bell-beaker package). ${ }^{96}$

Elementov, ki kažejo na stike s to kulturo, ne zasledimo le na keramičnih posodah, temveč jih najdemo tudi pri drugih najdbah z Dežmanovih koliš ${ }^{97}$ (sl. 5). Med značilne najdbe kulture zvončastih čaš lahko poleg teh uvrstimo tudi neokrašeno "spremno lončenino" (nem. Begleitkeramik; angl. common ware) pa tudi šila in bodala iz bakra, puščične osti in bodala iz kremena ter kamnite in koščene ščitnike za zapestje, kamnite bruse, koščene gumbe, obeske iz čekanov divjega prašiča in zobe različnih živali. ${ }^{98}$ Tipološko podobne najdbe so zastopane tudi v gradivu z Dežmanovih kolišč. Med kovinskimi predmeti naj navedemo šila $z$ rombično razširitvijo na zgornjem delu (sl. 5: 4). ${ }^{99}$ Podobna šila ${ }^{100}$ poznamo tudi $\mathrm{z}$ območja Trenta $\mathrm{v}$ severni Italiji, ${ }^{101}$ kjer so bila najdena skupaj s kosi keramike kulture zvončastih čaš. ${ }^{102}$ Severnoitalska šila italijanski raziskovalci opredeljujejo kot odraz vplivov oz. stikov z ljubljansko kulturo in jih označujejo kot šila tipa Ig II. ${ }^{103}$ Bakrena bodala

95 Besse 2004, sl. 2.1.

96 Dvorak 1993, t. 136: 1,8; Peška, Kalábek 2012, sl. 3 : 10; Leghissa 2017, 190, t. 127: 4.

97 Večina na II. Dežmanovem kolišču.

98 Glej npr. Strahm 1998, 27-29; Heyd 2001, sl. 4; Turek 2006, sl. 5; 13; 17; 18; Müller 2013, sl. 1; itd.

99 Korošec, Korošec 1969, t. 105: 1-5; Trampuž Orel, Heath 2008, t. 1: 12,13.

${ }^{100} \mathrm{~V}$ nasprotju s šili z Dežmanovih kolišč imajo koničast zaključek namesto ploščatega ter okrogel presek igle.

101 Perini 1972, sl. 9: 137; 10: 140,141; Bagolini, Pasquali, Pedrotti 1985, sl. 2.; Nicolis 1998a, 460 (op. 48).

102 Npr. Mottes, Nicolis 1998, 73 ss, sl. 1; 4.

103 Pri ogledu arheološkega muzeja v Vučedolu in pregledu še neobjavljenih najdb sem naletela na ilustracijo podobnega šila $\mathrm{z}$ rombično razširitvijo, vendar $\mathrm{z}$ iglo okroglega in ne pravokotnega preseka; odkrito je bilo med izkopavanji na najdišču Vučedol leta 1987. Kontekst in starost šila za zdaj nista znana. 
z Dežmanovih kolišč (sl. 5: 3) $)^{104}$ imajo z izjemo enega primerka trnast nastavek in so primerljiva $s$ številnimi bodali na območju med Dneprom in Karpati na vzhodu, v Grčiji in v zahodni Evropi, zlasti na Iberskem polotoku. ${ }^{105}$ Njihov časovni razpon je zelo širok, saj obsega prvo polovico 4 . in večji del 3. tisočletja pr. Kr. ${ }^{106}$ Ovalni kamniti brusi (sl. 5: 6) ${ }^{107}$ se pojavljajo predvsem v grobovih na najdiščih kulture zvončastih čaš od Moravske do Saške in Bavarske. ${ }^{108}$ Med kamnitimi najdbami z Dežmanovih koliščih so zastopane kremenaste listaste sulične osti ali bodala $\mathrm{z}$ retušami na robovih in po celotni površini (sl. 5: 5) ${ }^{109}$ Dobre primerjave jim najdemo na najdiščih Tržaškega Krasa ${ }^{110}$ in severne Italije, ${ }^{111}$ npr. Montesei di Serso v Trentu. ${ }^{112}$ Med zanimivejšimi najdbami z Dežmanovih kolišč je tudi z zarezami okrašen koščen ploščat predmet, ki ima luknjice ob robovih obeh daljših in najkrajše stranice (sl. 5:2). ${ }^{113}$ Njegove funkcije za zdaj ne moremo zanesljivo določiti. Glede na velikost, obliko in usločenost ga lahko primerjamo z zapestnimi zaščitnimi opornicami, t. i. brassardi, ${ }^{114}$ ki so značilne za kulturo zvončastih čaš, kulturo Polada in cetinsko kulturo. ${ }^{115}$ Po mnenju Kleijna so take koščene ploščice lahko zapestne zaščitne opornice, pasne spone, zapestnice ali preprosto le koščene ploščice, za katere je treba opraviti več analiz za natančnejšo opredelitev njihove funkcije. ${ }^{116}$

104 Korošec, Korošec 1969, t. 105: 6-11.

105 Glej Trampuž Orel, Heath 2008, 27 in tam navedena literatura; podobno bodalo je znano tudi z območja kulture zvončastih čaš na Moravskem (glej Turek 2006, sl. 5: 11).

106 Npr. v grobu R2 na grškem otoku Lefkada najdeno bodalo je datirano v obdobje EH II (tj. pribl. 2650-2200 pr. Kr.) (Branigan 1975, 37). Z najdišča Ezero v Bolgariji, s katerega izvirajo podobna bodala, sta dve radiokarbonski dataciji, ki kažeta na razpon 3522-3031 cal BC $(98,7 \%)$ in 2911-2464 cal BC (100 \%) (Primas 1996, 168; sl. 7.7: 6,7), itd.

107 Korošec, Korošec 1969, t. 77: 1-7.

108 Glej npr. Turek 2006, sl. 5: 29-30; 18: 7-8; 23: 6; 74.

109 Korošec, Korošec 1969, t. 73: 1-11; 74: 1-10; 75: 1; med najdbami z Dežmanovih kolišč ne najdemo kremenastih puščičnih osti; so pa številno zastopane na kolišču na Špici (neobjavljeno, hrani MGML).

110 Gilli, Montagnari Kokelj 1996, sl. 35.

111 Npr. Barfield 2001, 510 ss; Mottes 2001, 519 ss, sl. 1.

112 Mottes 2001, sl. 4 (prim. Korošec, Korošec 1969, t. $74: 1,3)$

113 Korošec, Korošec 1969, t. 87: 1.

114 Angl. bracers ali wrist-guards; nem. Armschutzplatte; it. bracciale d'arciere ali brassard. Blagoje Govedarica je omenjeni predmet interpretiral kot pasno spono (Govedarica 1989,45 ; t. XI: 1 ).

115 Npr. Turek 2013; 2015; Forenbaher 2013, 94.

116 Kleijne 2019, 136.
Posode ljubljanske kulture z Dežmanovih kolišč kažejo številne sorodnosti $\mathrm{z}$ najdbami s slovenskega in Tržaškega Krasa ter vzhodnojadranskega primorja, ki jih je Dimitrijević opredelil kot jadransko varianto ljubljanske kulture (karta 1). ${ }^{117} \mathrm{~K}$ tej varianti prištevajo Dimitrijević in drugi avtorji ${ }^{118}$ tudi najdbe iz črnogorskih in albanskih gomil, datirane na začetek 3. tisočletja pr. Kr.,npr. iz Male in Velike Grude, ${ }^{119}$ Podgorice-Grude Boljevića, ${ }^{120}$ Mogile na Rake, ${ }^{121}$ Kujave pri Danilovgradu ${ }^{122}$ itd.

A so keramične posode iz teh gomil po obliki in predvsem načinu izdelave ter okrasni motiviki bližje vučedolski kulturi kot pa ljubljanski oz. jadranski varianti ljubljanske kulture. Sklede na nogah ali nogicah iz teh gomil ${ }^{123}$ so okrašene $\mathrm{z}$ vrezi, vbodi in izdolbenimi površinami, kar je značilno za vučedolsko kulturo. Izjema je le skleda na nogi iz gomile Kujava pri Danilovgradu, za katero je v objavi navedeno, da je okrašena s koleščkom, ${ }^{124}$ a je iz objavljene fotografije težko presoditi ustreznost opredelitve načina krašenja. ${ }^{125}$ Tudi križni okras na notranji in zunanji strani je bolj podoben okrasni sintaksi vučedolskih posod. ${ }^{126}$ Poleg skled so v grobove pridajali okrašene keramične vrče, ki se prav tako pojavljajo že v vučedolski kulturi. ${ }^{127}$ Vrči so okrašeni na spodnjem delu in tudi na vratu, ${ }^{128}$ podobno kot vučedolske dvoročajne posode. ${ }^{129}$ Zaradi naštetega črnogorskih gomil ne pripisujem jadranski varianti ljubljanske kulture, ${ }^{130}$ temveč

117 Dimitrijević 1967; glej tudi Korošec 1962; Govedarica 1989.

118 Glej npr. Govedarica 1989; 2016; Marijanović 1991; 2003; Zagarčanin 2016; Forenbaher 2018a,b.

119 Npr. Govedarica 1989; Primas 1996.

120 Npr. Guštin, Preložnik 2015.

121 Zagarčanin 2016.

122 Lutovac 2017.

${ }^{123}$ Npr. Govedarica 1989, t. 42: 1a-b; 44: 1a-c; Primas 1996, sl. 5.1; 5.2; 5.3; 5.4; Guštin, Preložnik 2015, sl. 4: 1; Zagarčanin 2016, sl. 3: c,f; 5; 6. Posode opredeljujem na osnovi podanih opisov in predvsem fotografij in risb, ker nisem imela priložnosti za ogled originalnih predmetov.

124 Lutovac 2017, 61, t. 8.

125 Glede na objavljeno fotografijo je lahko okras na skledi izveden tudi z odtiskovanjem dvojno sukane vrvice.

126 Prim. npr. Hoffiller 1933, t. 8: 3a-b; Dimitrijević 1979,

t. 30: 5; 32: 3a; Balen 2005, t. 28: 93,94; Kulcsár 2013, sl. 4: 1c.

127 Glej Leghissa 2017, 104-117.

128 Govedarica 1989, t. 42: 2; Guštin, Preložnik 2015, sl. 4: 3; Zagarčanin 2016, sl. 3: c; 4.

129 Glej npr. Dimitrijević 1979, t. 33: 1,3,4,8; 36: 5.

130 Glej npr. Primas 1996; Maran 1998; 2007; Harrison, Heyd 2007; Guštin, Preložnik 2015. 
je zanje po mojem mnenju ustreznejša Maranova oznaka črnogorska varianta vučedolske kulture. ${ }^{131}$

Dobre analogije za različne vrste posod z Dežmanovih kolišč, opredeljene v ljubljansko kulturo, najdemo na najdiščih slovenskega in Tržaškega Krasa ter vzhodnojadranskega primorja, npr. za kroglaste dvoročajne posode s cilindričnim oz. lijakastim vratom tipa DvP4 (sl. 2: 3,4,9), ${ }^{132}$ visoke sklede $\mathrm{s}$ kroglastim trupom in lijakastim vratom tipa Vs2 (sl. 2: 14), ${ }^{133}$ visoke sklede z usločenim vratom tipa Vs3 (sl. 2: 12), ${ }^{134}$ polkroglaste sklede z odebeljenimi ustji tipa S1 (sl. 2: 16; 6), ${ }^{135}$ za sklede na votlih koničnih nogah tipa SnN9 $(s l .2: 18,19)^{136}$ in nazadnje za kroglaste skodele z lijakastimi vratovi tipa Sk 5 (sl. 2: 10,11,15). ${ }^{137}$ Vsa našteta lončenina in primerjalne najdbe so enako oz. podobno okrašene, ${ }^{138} \mathrm{tj}$. $\mathrm{z}$ odtisi na ploščat predmet navite niti, pogostokrat $\mathrm{v}$ kombinaciji $\mathrm{z}$ vbodi.

131 Glej Maran 2007, 8 ss; op. 36; glej tudi Maran 1998, op. 243. Zlasti v zadnjih letih je razširjena teza, da so črnogorske gomile del kulture "Jamnaja", za katero so značilni gomilni pokopi (glej npr. Harrison, Heyd 2007; Heyd 2011).

132 Prim. npr. Battaglia 1958-1959, 396, 397, sl. 152; Lonza 1973-1974, sl. 2: 18; 3: 16; 5: 12; Marković 1974, 9, t. 4: 1,2,7,9; Marijanović 1978, 177 ss, t. I: 1; Cannarella, Pitti 1978-1981, sl. 5: 3-5; Marović 1980, 34, sl. 8; Marković 1985, t. 29: 2,3,6,7; Milošević, Govedarica 1986, t. 1: 1; 2: 5-9; 3: 1,7; 4: 6; 6: 4; Turk et al. 1993, t. 14: 15; 16: 5,15-17; Montagnari Kokelj, Crismani 1997, sl. 13: 109; 31: 278; Gilli, Petrucci, Salzani 2000, 126, t. 5: 13; Marijanović 2003, t. 21: 1,6; 25: 5; 26: 3; Čuka 2009, t. 3: 13; Radić Rossi 2011, 117-118, t. 1: 1-2; itd.

133 Prim. npr. Korošec 1956, t. 2: 3; 3: 2,5: 3; Dimitrijević 1967, t. 7: 4; Forenbaher, Vranjican 1985, t. 5: 2,3; Montagnari Kokelj, Crismani 1997, sl. 12: 93; 13: 107,109; Gilli, Montagnari 1996, sl. 38: 255; Montagnari Kokelj, Greif, Presello 2002, t. 11: 119; itd.

134 Prim. npr. Dimitrijević 1967, t. 7: 1; Milošević, Govedarica 1986, t. 9: 1-3; 10: 2?; Turk et al. 1993, t. 14: 22; 16: 18; Montagnari Kokelj, Crismani 1997, sl. 13: 106.

135 Prim. npr. Lonza 1973-1974, sl. 2; Milošević, Govedarica 1986, t. $1: 3 ; 7: 1-3,5 ; 8: 3,5,6 ; 9: 6 ; 10: 3 ; 11: 1 ; 12$ : 1; Barfield 1997-1998, sl. 12: 46,47; Hulina, Forenbaher, Miracle 2011, 159, 161, sl. 16: 3.f; t. 4: 5; itd.

136 Prim. npr. Milošević, Govedarica 1986, t. 1: 5; 8: 1; 11: 13; 12: 2; Govedarica 1989, t. 19: 8a-b.

137 Prim. npr. Lonza 1973-1974, sl. 4: 12; Forenbaher, Vranjican 1985, t. 5: 1; Gilli, Montagnari Kokelj 1993, sl. 35: 341; 43: 425; Turk et al. 1993, t. 14: 15; Montagnari Kokelj, Crismani 1997, sl. 12: 94; Čuka 2009, t. 3: 14.

${ }^{138} \mathrm{Z}$ izjemo primerkov lončenine $\mathrm{z}$ Ljubljanskega barja, slovenskega in Tržaškega Krasa nisem imela možnosti neposrednega ogleda originalov, da bi preverila, ali gre za enak način krašenja.
Med območjem Ljubljanskega barja in preostalim območjem razprostranjenosti ljubljanske kulture se v materialni kulturi kažejo tudi razlike, ${ }^{139}$ predvsem $\mathrm{v}$ številčnosti in raznolikosti keramičnih oblik. V primerjavi s keramiko na Ljubljanskem barju, predvsem na Dežmanovih koliščih, so npr. v vzhodnojadranskem primorju povsem neznani kroglasto oblikovani vrči z lijakastimi vratovi tipa V4 (sl. 2: 1,2,5) in bučaste posode (sl. 2: 6-8). Glede motivike okrasa pa razlike opažamo predvsem pri skledah tipa S1 z ravno (včasih tudi poševno) odrezanim robom, primerki teh iz jadranskega primorja so bogatejše okrašeni ne le na robu ustja in zgornjem delu recipienta, temveč večkrat tudi po celotni zunanji površini (sl. 6: 7-17), medtem ko so sklede iz tržaških jam in primerek $\mathrm{z}$ istrskega najdišča okrašeni skoraj enako kot sklede $\mathrm{z}$ Ljubljanskega barja ${ }^{140}$ (sl. 6: primerjaj 1 z 2-6)..$^{141}$

Med lončenino, ki smo jo opredelili v mlajšo fazo Dežmanovih kolišč, so poleg posod ljubljanske kulture in takih, ki odražajo stare elemente vučedolske kulture (t. i. ljubljanskobarjanske variante), kulture vrvičaste keramike in kulture kroglastih amfor ter nove vplive kulture zvončastih čaš, tudi take, ki imajo primerjave predvsem $v$ krogih kulture Somogyvár-Vinkovci in Makó-Kosihy-Čaka. Mednje spadajo npr. velike shrambne dvoročajne ovalne posode (sl. 2: 29), ${ }^{142}$ posode z odebeljenimi robovi

139 Med poglavitne razlike spada tudi tip najdišča: na Ljubljanskem barju gre za kratkotrajne koliščarske naselbine, na preostalem območju razprostranjenosti pa predvsem za jamska najdišča, ki so bila obiskana/naseljena dlje časa, vendar nekontinuirano. Kot je že omenjeno na več mestih, so take razlike $\mathrm{v}$ materialni kulturi lahko posledica stanja, načina in obsega raziskav, lahko pa so tudi kulturološko pogojene.

140 Izjema je le skleda s kolišča na Partih, ki je na zunanji površini tik ob robu okrašena $\mathrm{z}$ vodoravnimi črtami in šrafiranimi trikotniki (Harej 1978, t. 3: 3), torej podobno kot primerki iz vzhodnojadranskega primorja. Podobno okrašene kot sklede $\mathrm{z}$ Dežmanovih kolišč so tudi še neobjavljene sklede s kolišča Špica pri Ljubljani (glej npr. Klasinc et al. 2010, t. 12: levo zgoraj).

${ }^{141}$ Te razlike v okrasu spominjajo na spremembe stilov $\mathrm{v}$ kulturi zvončastih čaš. Nicolis je v okviru kulture zvončastih čaš severne Italije navedel zanimiv razvoj oziroma spremembo okrasa - od preprostega zonalnega okrasa do povsem zapolnjenega stila $\mathrm{z}$ značilnim naraščajočim baročnim “horror vacui”, ki se kaže v postopnem zapolnjevanju praznega prostora (Nicolis 1998b, 61).

142 Leghissa 2017, t. 70: 1-2 (Korošec, Korošec 1969 , t. 8: 4; 21: 3), prim. npr. z Vladár 1962, t. I: 7; Marković 1978, 24, t. VIII: 2; Marković 1981, t. 7: 9; 8: 5; Tasić 1984, t. III: 4,5,7; IV: 2,7,10; Bandi 1984, t. XXVIII: 1; Bondár 1994, sl. 3: 1; Bondár 1995, 205, sl. 14: A/3; t. 172: 323; 
ustij (sl. 2: 30), ${ }^{143}$ konične sklede (sl. 2: 23) ${ }^{144}$ in polkroglaste skodele (sl. 2: 25). ${ }^{145}$

Podobne posode so zastopane tudi na drugih koliščih 3. tisočletja pr. Kr. na Ljubljanskem barju, kot so Parte (sl. 7: 17-24; karta 1: 2), Založnica pri Kamniku pod Krimom (karta 1: 4), Dušanovo (= Črni graben) (karta 1: 5,6) in Špica (karta 1: 7). Na podobnosti z najdbami s Part sta v objavi najdišča Založnica ${ }^{146}$ že opozorila Velušček in Čufarjeva, primerjave pa sta našla predvsem med najdbami z madžarskega najdišča Börzönce, ki je pripisano kulturi Somogyvár-Vinkovci, kamor sta uvrstila Založnico in Parte. ${ }^{147}$ Te podobnosti so očitne, vendar je mogoče opaziti tudi nekaj razlik. V repertoarju Založnice in Part (pa tudi Dežmanovih in drugih kolišč 3. tisočletja pr. Kr.) ne zasledimo cele vrste značilnih oblik kulture Somogyvár-Vinkovci, kot so vrči z zelo visokim usločenim ali cilindričnim vratom, visoke sklede $\mathrm{z}$ ročaji in ostrimi klekastimi prehodi ter sklede na visokih votlih koničnih nogah. ${ }^{148}$

Ključnega pomena pa je to, da se na prej omenjenih koliščih Ljubljanskega barja najdbe, pripisane kulturi Somogyvár-Vinkovci, pojavljajo skupaj z značilno keramiko ljubljanske kulture.

Ruttkay 2003, sl. 4; Kulcsár 2009, 154 ss, 334; sl. 35: XIV/1; 67: XV/1,2,3; Vollmann 2009, t. 2: 12; Šavel, Sankovič 2010, 53, npr. G147, G180, G181, G399, G565-568, G1335.

143 Leghissa 2017, t. 71:1-4; 72: 1-5 (Korošec, Korošec 1969, t. 63: 4; 65: 2; 66: 1-7), prim. npr. z Dimitrijević 1966, 30; Kulcsár 2009, 329, sl. 65: XIV/4 in XIV/4a; t. 8: 10; 17: 1; Šavel, Sankovič 2010, G54, G127, G215, G242, G286 itd.; Guštin, Zorko 2013, t. 1: 10; 2: 9; Kerman 2014, sl. 1.5 : $5 ; 1.6: 9$.

144 Leghissa 2017, t. 90: 4-7 (Korošec, Korošec 1969, t. 50: 3,4,7; 65: 7), prim. npr. z Vladár 1962, sl. 20: 1; 21: 4; Toth 2001, sl. 8: 8; Kulcsár 2009, sl. 22: VII/11,VII/14; sl. 26: VII/26; Šavel, Sankovič 2010, 43, sl. 24: 2.

145 Leghissa 2017, t. 112: 1-5 (Korošec, Korošec 1969, t. 28: 5; 50: 8,9,11,13;110: 1); prim. npr. z Bondár 2003, sl. 6: 1; 10: 2; Kulcsár 2009, t. 11: 3; Šavel, Sankovič 2010, 47 ss, sl. 25: 1,5; Guštin, Zorko 2013, t. 1: 3.

146 Velušček, Čufar 2003.

147 Ib., 129-130.

148 Glej npr. Kulcsár 2009, sl. 49: I/12-I/16; 51: II/7,II/8; 54: VII/ 2-5,11,12; 59; 60; glej npr. tudi Šavel, Sankovič 2010, G6, G10, G13, G31, G32, G141, G209, G371-G373, G430, itd. Podobno, kot smo že omenili pri opredeljevanju ljubljanske kulture, kaže tudi v tem primeru opozoriti na problematičnost pripisovanja najdišč na Ljubljanskem barju kulturi Somogyvár-Vinkovci z vidika klasičnega kulturološkega pristopa. Najdišča Ljubljanskega barja so od osrednje razprostranjenosti kulture Somogyvár-Vinkovci namreč precej oddaljena in so posebnost $\mathrm{v}$ naselbinskem, prostorskem in časovnem smislu v primerjavi s preostalimi najdišči tega kulturnega fenomena.
Na kolišču Parte, raziskanem v prejšnjem stoletju, so bile $\mathrm{v}$ isti kulturni plasti odkrite značilne najdbe za ljubljansko kulturo in tudi take, ki po mnenju Veluščka in sodelavcev sodijo v okvir kulture Somogyvár-Vinkovci. Obe skupini najdb sta zastopani v okviru istega raziskanega območja, ne da bi bili prostorsko ločeni, zato je iz njihove stratigrafske lege mogoče sklepati na njuno sočasnost. ${ }^{149}$ Tudi na najdiščih Založnica, Dušanovo in Špica so bile v eni kulturni plasti brez vsakršnih vidnih koncentracij zastopane najdbe, značilne za ljubljansko kulturo, in take, ki kažejo primerjave s kulturo Somogyvár-Vinkovci. Vsa prej omenjena najdišča so enofazna in praviloma kratkotrajno poseljena. ${ }^{150}$

$\mathrm{Na}$ morebitno sočasnost ljubljanske kulture in kulture Somogyvár-Vinkovci je opozoril že Dimitrijević v zvezi s fragmentom tipične posode ljubljanske kulture, odkritim med izkopavanji najdišča Vinkovci leta 1877/78 v sondi 55. Fragment je opredelil v horizont Vinkovci s pripombo, da bi lahko izviral iz jame, pripisane temu horizontu. ${ }^{151}$ A je stratigrafijo $\mathrm{v}$ tej sondi poškodoval steber, postavljen $\mathrm{v}$ začetku prejšnjega stoletja, zato tega fragmenta ne moremo šteti kot zanesljiv argument za sočasnost obeh kultur.

Ob tem se postavlja vprašanje, ali je pripisovanje nekaterih najdb z Dežmanovih kolišč kulturi Somogyvár-Vinkovci ustrezno. Glavna novost in značilnost mlajše faze na Dežmanovih koliščih je pojav keramike ljubljanske kulture, ki je večinoma finejša in okrašena $\mathrm{z}$ vrezi/vtisi. Na preostalih najdiščih Ljubljanskega barja je keramika ljubljanske kulture manj številna $\mathrm{z}$ izjemo Špice ${ }^{152}$ in Part (glej seznam 1) (npr. sl. 7: 1-16). ${ }^{153}$ Med večinoma

149 Kolišče Parte-Iščica, oddaljeno približno $85 \mathrm{~m}$ vzhodno od območja Harejevih izkopavanj na kolišču Parte, je starejše, datirano je na konec 28. st. in v 27. st. pr. Kr. Podrobnejša kulturološka analiza povezav med obema koliščema doslej ni bila izvedena; nekatere v strugi Iščice odkrite najdbe kažejo podobnosti $\mathrm{z}$ najdbami vučedolske faze Dežmanovih kolišč, kulture Somogyvár-Vinkovci in $\mathrm{v}$ enem primeru $\mathrm{z}$ najdbami ljubljanske kulture, nekatere druge pa s pramenasto keramiko zgodnje bronaste dobe (glej še Velušček, Čufar, Levanič 2000).

150 Glede nesinhronizirane krivulje z Založnice glej tu op. 48.

151 Dimitrijević 1982, 18; t. 8: 5.

${ }^{152} \mathrm{Na}$ kolišču na Špici je keramika ljubljanske kulture zelo pogosta.

${ }^{153}$ Drugačno razmerje med keramiko ljubljanske kulture in tisto, ki kaže predvsem na vplive kulture Somogyvár-Vinkovci, je morda posledica stanja in obsega raziskav. Primerjava vseh kolišč na Ljubljanskem barju ni mogoča, 
neokrašenimi in bolj grobimi posodami druge faze na Dežmanovih koliščih so tudi take, ki jih povezujemo z vplivi kultur Somogyvár-Vinkovci in Makó-Kosihy-Čaka. Ne le na koliščih Ljubljanskega barja, temveč tudi na najdiščih slovenskega in Tržaškega Krasa ter vzhodnojadranske obale zasledimo finejšo okrašeno lončenino ljubljanske kulture skupaj z grobo keramiko, ki spominja na tipe posod kulture Somogyvár-Vinkovci. ${ }^{154}$ Zanimivo je, da v repertoarju kulture zvončastih čaš nastopajo ob značilnih okrašenih posodah prav tako neokrašene in bolj grobe posode, $t$. i. spremna lončenina, ${ }^{155} \mathrm{ki} \mathrm{v}$ številnih potezah spominja na nekatere oblike posod kultur Somogyvár-Vinkovci, Makó-Kosihy-Čaka in Nagyrév. Taka je npr. keramika iz naselbine Albertfalva pri Budimpešti pripisana skupini Csepel kulture

ker so bila raziskana $\mathrm{v}$ različnem obsegu in na različne načine. Na Dežmanovih kolišč je bila z izkopavanji raziskana pribl. $12.836 \mathrm{~m}^{2}$ velika površina, na kolišču Parte $640 \mathrm{~m}^{2}$. Za kolišči Založnica in Dušanovo (= Črni graben) je raziskano površino težko natančneje izračunati, ker je šlo za dokumentiranje posegov ob čiščenju drenažnih jarkov, in ne za arheološka izkopavanja. Dežman pa je med izkopavanji pobiral večinoma le cele posode in okrašene fragmente, množico neokrašenih fragmentov pa je pustil na terenu. $O$ tem pričajo številni fragmenti neokrašenih posod, ki so ležali v prekopanih plasteh, na katere je naletela Tatjana Bregant med sondiranjem območja Dežmanovih kolišč v šestdesetih letih prejšnjega stoletja (glej nazadnje Leghissa 2017 z navedeno literaturo). Možne so še drugačne razlage razlik med kolišči na Ljubljanskem barju, denimo drugačen status naselbine: središčna naselbina/območje (Dežmanova kolišča) in satelitske naselbine (kolišča na južnem obrobju Ljubljanskega barja). A te hipoteze za zdaj ni mogoče preveriti. Kot je že omenjeno v op. 139, zasledimo razlike prav tako med kolišči Ljubljanskega barja in preostalimi najdišči ljubljanske kulture, kjer gre za drug tip najdišča - jame.

${ }^{154}$ Npr. vrči z bikonično ali kroglasto oblikovanim trupom, posode $\mathrm{z}$ odebeljenim robom ustja, lonci z lijakastimi vratovi. Glej npr. Podmol pri Kastelcu - skupek D (Turk et al. 1993, t. 13: 15,19; 14: 5; 15: 1-3,9; 16: 2,6,9,22,23,25,29); na Tržaškem Krasu glej npr. Grotta Teresiana/Terezijina jama (Barfield 1997-1998, sl. 12: 45); Grotta Cotariova/Čotarjeva jama (Lonza 1973-1974, sl. 4: 10; Barfield 1997-1998, sl. 15: 25); Grotta degli Zingari/ Ciganska jama (Gilli, Montagnari Kokelj 1996, sl. 37: 231-235; 38: 241,244-249); Grotta dei Ciclami/Orehova pejca (Gilli, Montagnari Kokelj 1993, 154 ss, sl. 29: 268; 43: 417-422,426; 51: 504,504); na vzhodnojadranskem območju: Hateljska pećina faza III (Marijanović 2003, 35 ss, t. 8: 2,3; 9: 1-2; 10: 1-4); Varvara A-1 (Čović 1978, t. $1 ; 2: 6,7 ; 3: 6 ; 7)$ itd.

155 Nem. Begleitkeramik (glej tudi Leghissa 2017, 104-112).
Zvončastih čaš. ${ }^{156}$ Večinoma grobo in neokrašeno (oz. redko okrašeno) keramiko na Dežmanovih koliščih mlajše faze in kolišča Parte ${ }^{157}$ kaže torej obravnavati v okviru ljubljanske kulture, v kateri se odražajo tudi vplivi kulture Somogyvár-Vinkovci z območja Panonske nižine.

\section{ABSOLUTNI ČASOVNI OKVIR LJUBLJANSKE KULTURE}

Poleg II. Dežmanovega kolišča obravnavamo v okviru ljubljanske kulture tudi koliščarske naselbine Parte, Špica, Založnica in Dušanovo na Ljubljanskem barju. $\mathrm{Na}$ omenjenih najdiščih so bile opravljene večinoma dendrokronološke analize, ${ }^{158}$ pridobljeni rezultati pa so merodajni za datiranje ljubljanske kulture, ne pa tudi kulture Somogyvár-Vinkovci. Geografsko najbližje II. Dežmanovemu kolišču je kolišče Parte, na katerem so potekala v letih 1976-1981 izkopavanja. ${ }^{159} \mathrm{Na} 640 \mathrm{~m}^{2}$ veliki površini je v eni kulturni plasti ležala množica lesenih kolov in najdb, ki jih pripisujemo ljubljanski kulturi, ${ }^{160}$ in tudi takih, ki kažejo vplive kulture Somogyvár-Vinkovci. ${ }^{161}$ Po dendrokronološkem datiranju sega najstarejša gradbena dejavnost na kolišču Parte na konec 26. st. pr. Kr., najživahnejša v prvo polovico 25. st. pr. Kr., najmlajša pa okvirno v sredino 25. st. pr. Kr. (sl. 8). ${ }^{162}$ Natančne dendrokronološke datacije

156 Endrődi, Reményi 2016, 108-114, 118-121; med gradivom iz Albertfalve je tudi fragment sklede s podobnim okrasom na notranji površini ustja, kot ga ima keramika ljubljanske kulture (Endrődi, Reményi 2016, t. 4: 6).

${ }^{157}$ Verjetno tudi podobno keramiko s kolišč Založnica, Dušanovo (= Črni graben) in Špica.

$158 \mathrm{Za}$ natančnejše datiranje krivulj lesenih kolov je bila uporabljena metoda wiggle-matching, izbrane branike lesa s točno določenih odsekov na kronologijah so bile radiokarbonsko datirane, nekatere $\mathrm{z}$ do 2 sigma natančnosti \pm 10 let (glej tudi Čufar et al. 2010; Velušček, Čufar 2014; Velušček 2014).

$159 \mathrm{~V}$ tem kontekstu ne obravnavamo dendrokronoloških analiz s kolišča Parte-Iščica, ker so najdbe od tam kronološko in kulturološko heterogene.

160 Za najdbe, ki smo jih pripisali ljubljanski kulturi, glej npr. Korošec 1964, t. 1: 3; Harej 1978, t. 1: 10; 2: 8,9; 7: 6; 9: 1,2; Harej 1981-1982, t. 9: 9; 10: 15; 1, 11: 5; 17: 4; 18: 1; 21: 7,9-11,13-16; Harej 1987, t. 8: 1,3; itd.

${ }^{161}$ Za najdbe, ki kažejo na vplive kulture Somogyvár-Vinkovci, glej npr. Korošec 1964, t. 1: 8; 2: 1; 3: 1; 4: 1,2; 8: 1; 9: 9; Harej 1978, t. 4: 7; 10: 5; Harej 1981-1982, t. $8: 5 ; 11: 4 ; 12: 2 ; 18: 2 ; 22: 1 ; 27: 1 ; 30: 7 ; 33: 10$; Harej 1987 , t. $3: 1,3,9 ; 4: 12 ; 5: 3 ; 6: 5 ; 15: 2,4-9 ; 20: 7$; prim. še Velušček, Čufar 2003.

162 Velušček, Čufar 2003, 128, pril. 1. 
poznamo tudi s kolišč Založnica in Dušanovo, kjer je bilo najdenih manj tipičnih oblik ljubljanske kulture in več t. i. spremne lončenine, torej take, ki odseva vplive kulture Somogyvár-Vinkovci. ${ }^{163} \mathrm{Na}$ kolišču Založnica so dendrokronološke analize pokazale na 90 let dolgo obdobje gradbenih aktivnosti, ki se je začelo konec 26. st. pr. Kr. in se zaključilo v zadnji četrtini 25. st. pr. Kr. (sl. 8). ${ }^{164}$ Izjemno kratek časovni interval so pokazale dendrokronološke analize na kolišču Dušanovo, na katerem so gradbene aktivnosti potekale med letoma 2502 in 2493 pr. Kr. ${ }^{165}$ Analize lesa so prispevale še en zanimiv podatek: na Dušanovem so sekali les, ki so ga pridobili s pomlajevanjem na panju in $\mathrm{z}$ redčenjem gozdnih sestojev, kar kaže na vsaj nekaj desetletij zgodnejšo prisotnost človeka na tem območju. ${ }^{166}$ Ta podatek sicer še ne zadostuje za potrditev morebitne starejše faze kolišča, saj dendrokronološke datacije kažejo na eno kratkotrajno fazo, pa tudi tam odkrite najdbe so dokaj uniformne. ${ }^{167}$ Dendrokronoloških podatkov za kolišče Špica v Ljubljani še nimamo, ker analize še niso končane. Poznamo pa radiokarbonsko datacijo, odvzeto za palinološke raziskave. ${ }^{168} \mathrm{Iz}$ plasti SE 1004, ki je ležala pod spodnjo kulturno plastjo SE $1035,{ }^{169}$ je bil radiokarbonsko datiran vzorec želoda hrasta. Pri kalibraciji $2 \sigma$ kaže večji odstotek verjetnosti (90,5\%) razpon od 2677 do

163 Glej Založnica (Velušček, Čufar 2003, t. 2: 5; 3: 2; 4: 8; 8: 7; 11: 9; 13:6;14: 4; 15: 9; Velušček, Toškan, Čufar 2011, t. 2: 10); Dušanovo (= Črni graben) (Velušček, Toškan, Čufar 2011, t. 3: 6,7; neobjavljeno gradivo začasno hrani Inštitut za arheologijo ZRC SAZU).

164 Velušček, Čufar 2003, 126, pril. 1; Velušček, Toškan, Čufar 2011, 54, sl. 3, tab. 3; glej tudi Čufar, Velušček, Kromer 2013. V tem prispevku ne obravnavamo kronologije Zal-FRSP2, ker ni sinhronizirana. Iz Založnice izvira tudi konjska kost, radiokarbonsko datirana v 28. in 27. st. pr. Kr. Kakšno mesto ima najdba v kontekstu naselbine Založnica, ostaja odprto (najdba še ni objavljena; za podatek se zahvaljujem Borutu Toškanu, arheozoologu na Inštitutu za arheologijo ZRC SAZU).

165 Velušček, Toškan, Čufar 2011, 61; Kržišnik 2014, 34-35.

166 Kržišnik 2014, 47.

167 Lahko pa bi šlo za doslej še neodkrito starejšo naselbino kje v bližini.

168 Andrič et al. 2017.

$169 \mathrm{~V}$ objavi je vzorec napačno pripisan spodnjemu delu kulturne plasti; po natančnem pregledu profila, fotografskega arhiva, stratigrafskih opisov in preliminarnega poročila izkopavanj (Klasinc et al. 2010; hrani ZVKDS) izvira analizirani vzorec iz plasti SE 1004, ki kaže na poplavo pred gradnjo koliščarske vasi. Vodjema izkopavanj Roku Klasincu in Ireni Šinkovec se zahvaljujem za posredovanje dokumentarnih fotografij in podatkov o stratigrafskih enotah.
2469 cal BC. ${ }^{170}$ Datacija ponuja torej terminus post quem ali ad quem za gradnjo kolišča Špica, katerega potemtakem opredeljujemo okvirno na sredino 3 . tisočletja pr. Kr. ${ }^{171}$

Poleg dendrokronoloških datacij z najdišč Ljubljanskega barja imamo na voljo še nekaj radiokarbonskih datiranj z drugih najdišč, katerih najdbe pripisujemo ljubljanski kulturi. Z jadranskega najdišča Grapčeva špilja na otoku Hvaru (karta 1: 38) sta znani dve radiokarbonski dataciji in ena iz jamskega najdišča Odmut pri naselju Plužine v Črni gori (karta 1: 48). ${ }^{172} \mathrm{~V}$ Grapčevi špilji sta bili datirani dve plasti, v katerih je bilo najdenih nekaj fragmentov t. i. ljubljanske lončenine in fragment z grobo žlebljenim okrasom. ${ }^{173} \mathrm{~V}$ Odmutu je bila datirana plast 3 , iz katere izvira večina lončenine ljubljanske kulture. ${ }^{174} \mathrm{Z}$ istrskega najdišča Pupićina peć (karta 1: 28) je znana datacija konteksta 605, $\mathrm{v}$ katerem so bile najdbe ljubljanske in cetinske kulture pa tudi tipološko starejša in mlajša lončenina. ${ }^{175}$ Tri radiokarbonske datacije so znane $s$ Tržaškega Krasa, ena iz jame Grotta dei Ciclami/ Orehove pejce (karta 1:23) in dve iz Grotta del Mitreo/Mitrejeve jame (karta 1: 14).

Skupen razpon vseh teh datacij je zelo širok, saj zaobjame celotno 3. tisočletje pr. Kr. (sl. 9). Najširši je razpon datacije z Odmuta (vzorec Z-409), ki pri kalibraciji $2 \sigma$ kaže večji odstotek verjetnosti $(84,7 \%)$ od 3138 do 2574 cal BC. Tako širok razpon ne preseneča, saj ima večina

170 Andrič et al. 2017, 484, sl. 2; 4.

${ }^{171} \mathrm{Z}$ Dežmanovih kolišč pri Igu so na voljo tri radiokarbonske datacije, dve kažeta okviren časovni razpon od 2676 do 2473 cal BC (2 б; 89,5 \%) Oz. 2620 DO 2472 CAL BC ( $\sigma ; 95,4 \%)$, pripisali pa smo jih $\mathrm{z}$ veliko verjetnostjo prvemu Dežmanovemu kolišču. Če je ta pripadnost pravilna, sta ti dataciji merodajni za datiranje vučedolske faze na Dežmanovih koliščih. Tretja datacija kaže na razpon od 2620 do 2468 cal BC (2 б; 95,4 \%), njeno pripadnost določenemu kolišču pa ni bilo mogoče ugotoviti (glej Leghissa 2017; 2018). Nekaj radiokarbonskih datacij je znanih tudi s kolišča Parte, vendar z zelo širokim časovnim razponom, ki sega od 29. do 21. st. pr. Kr. (Durman, Obelić 1989). Tako širok razpon datacij ne preseneča, ker so bile pridobljene v laboratoriju $\mathrm{v}$ Zagrebu in ne gre $\mathrm{za}$ t. i. akceratorske datacije, zato so tudi manj natančne. Večina rezultatov vzorcev, analiziranih v tem laboratoriju, kaže na diskrepance in zato niso zanesljivi (glej tudi Črešnar, Teržan 2014a, 654 ss).

172 Datacije iz črnogorskih gomil niso upoštevane, ker teh gomil ne obravnavamo v okviru ljubljanske kulture.

173 Forenbaher 2018a, 146.

174 Marković 1974, 8, t. I.

175 Hulina et al. 2011, 141, 163-164; Forenbaher 2018a, 148 . 
vzorcev, analiziranih v zagrebškem laboratoriju, podobno zelo široke razpone in so zato manj uporabni. ${ }^{176}$ Tudi uporabnost datacij $\mathrm{z}$ najdišča Grapčeva špilja je problematična, saj se dataciji nanašata na štiri plasti, ki pripadajo sredini in vrhuncu faze 4 . Fragmenti, ki so bližji t. i. cetinskemu stilu (po Forenbaherju), so ležali $\mathrm{v}$ starejših plasteh faze 4 in $\mathrm{v}$ starejših plasteh faze 5, medtem ko so bili fragmenti, bližji t. i. ljubljansko-jadranskemu stilu (po Forenbaherju), najdeni v mlajših plasteh faze 4 . Kot je opozoril že Forenbaher, kaže ta situacija na verjetno premešan kontekst. ${ }^{177}$ Datacije $s$ Tržaškega Krasa pa za časovno umestitev ljubljanske kulture niso primerne zato, ker se ne nanašajo nanjo $\mathrm{v}$ ožjem smislu. Najdbe z datiranih odsekov sodijo namreč v okvir vučedolske, ljubljanske, cetinske in tudi kaštelirske kulture iz srednje bronaste dobe. ${ }^{178}$

V primerjavi z datacijami iz jamskih najdišč Tržaškega Krasa in vzhodnojadranskega primorja so datacije, ki so na voljo za Ljubljansko barje, precej bolj natančne, saj izvirajo iz zelo kratkotrajnih naselbinskih kontekstov. Potemtakem lahko ljubljansko kulturo na Ljubljanskem barju kronološko opredelimo na konec 26. in v 25. st. pr. Kr.

Tezo o pojavu in razvoju ljubljanske kulture prav na Ljubljanskem barju podpirajo različni argumenti. Med keramičnimi najdbami z Dežmanovih kolišč so oblike, ki kažejo tradicijo vučedolske faze kolišča, vendar že okrašene $\mathrm{v}$ maniri ljubljanske kulture, tj. z odtisi na ploščat predmet navite niti: npr. skleda na križni nogi, sklede na visoki polni nogi ter visoke sklede in skodele s konkavno usločenim vratom. ${ }^{179}$ Tudi med t. i. spremno keramiko, ki kaže na povezave predvsem s kulturo Somogyvár-Vinkovci, zasledimo starejše oblike (npr. na Dežmanovih koliščih; sl. 2: 22,26), ${ }^{180}$ te prav tako nakazujejo vučedolsko tradicijo in $\mathrm{s}$ tem na kontinuiran razvoj. Na nekaterih posodah iz starejše faze Dežmanovih kolišč pa že zasledimo elemente kulture vrvičaste keramike, npr. na kroglastih dvoročajnih posodah. ${ }^{181}$ Poleg tega je

176 Glej Črešnar, Teržan 2014a, 656.

177 Forenbaher 2018a, 140, 146; glej tudi Forenbaher et al. 2010, 342, sl. 6 .

178 Glej Gilli, Montagnari Kokelj 1993; Montagnari Kokelj, Crismani 1997.

179 Leghissa 2017, t. 86: 1-5; 98: 5; 109: 2,3; 118: 5-9 (Korošec, Korošec 1969, t. 33: 1-8; 37: 1; 38: 2; 56: 10,14; 113: 1,5; 119: 6).

180 Glej npr. Leghissa 2017, 138-139 (za lonce tipa L2), 153-155 (za visoke sklede tipa VS1).

${ }^{181}$ Leghissa 2017, 259-262. na območju Ljubljanskega barja raznolikost tipov posodja največja, od vrčev, dvoročajnih posod, buč, visokih skled do raznovrstnih skodel, ki jih na drugih najdiščih s t. i. ljubljansko keramiko ne zasledimo. Po mojem mnenju te značilnosti lončenine nakazujejo neprekinjen razvoj iz starejše v mlajšo fazo Dežmanovih kolišč.

\section{SKLEP}

Najdbe ljubljanske kulture opredeljujejo mlajšo fazo na Dežmanovih koliščih pri Igu, ki so jo doslej različni avtorji ${ }^{182}$ opredeljevali le $\mathrm{z}$ vidika finejše, večinoma okrašene keramike. $Z$ novo analizo najdb z Dežmanovih kolišč je bilo mogoče na novo opredeliti značilnosti keramičnega repertoarja te kulture. Glavna značilnost finejše keramike ljubljanske kulture je okras, izveden $\mathrm{z}$ odtisi na ploščat predmet navite niti, pogosto $\mathrm{v}$ kombinaciji z vbodi. Med oblikami prevladujejo kroglaste posode z lijakastimi ali cilindričnimi vratovi, dna so pogosto sferična in imajo tu in tam okroglo vdolbino na sredini. Kot spremno keramiko označujemo lončenino, ki je redkeje okrašena in odseva podobnosti, morda vplive kultur Somogyvár-Vinkovci in Makó-Kosihy-Čaka.

Izvorno območje ljubljanske kulture so bila verjetno prav Dežmanova kolišča na Ljubljanskem barju. V nekaterih oblikah posod iz mlajše faze Dežmanovih kolišč odseva starejša tradicija vučedolske kulture, a so kljub "stari" obliki okrašene na nov način (npr. sklede na nogah). Vučedolska tradicija se kaže tudi v nekaterih podobnih okrasnih motivih, iz česar je mogoče sklepati, da se je ljubljanska kultura formirala na substratu vučedolske kulture oz. njene ljubljansko barjanske variante in pod vplivi/stiki/ impulzi z območja kultur vrvičaste keramike in kroglastih amfor pa tudi kulture zvončastih čaš. $\mathrm{V}$ t. i. spremni lončenini, večinoma neokrašeni, pa se odražajo predvsem podobnosti s kulturo Somogyvár-Vinkovci. To se zdi razumljivo, saj sta tako kultura Somogyvár-Vinkovci kot ljubljanska kultura nastali na osnovi vučedolske kulture in se oprli na njeno tradicijo na eni strani, na drugi pa sta sprejemali elemente različnih kultur in $z$ njimi vsaka po svoje obogatili svoj kulturni izraz. Kultura Somogyvár-Vinkovci je dajala pečat prostoru Karpatske kotline, medtem ko je ljubljanska kultura predstavljala most proti zahodu do Trža-

182 Npr. Korošec 1958-1959, Dimitrijević 1967; Govedarica 1989; Forenbaher 2018a; itd. 
škega Krasa in severne Italije ter vzhodnih obal Jadranskega morja, kjer se prav tako oblikujejo lokalne posebnosti. Na osnovi dendrokronoloških datacij, predvsem tistih s kolišča Parte, od koder je veliko okrašenih posod in neokrašenih fragmentov spremne lončenine, in s kolišča Založnica, sodi ljubljanska kultura na Ljubljanskem barju na konec 26. in v 25. stoletju pr. Kr.

Večjega širjenja elementov ljubljanske kulture proti vzhodu ni zaznati, saj so vzhodneje od Ljubljanskega barja doslej znana le tri najdišča: Vinkovci v Slavoniji (karta 1: 49), ${ }^{183}$ Hrustovača v Bosni (karta 1: 31) ${ }^{184}$ in Bük v severozahodni Madžarski (karta 1: 50). ${ }^{185} \mathrm{~S}$ teh najdišč so znane le posamične najdbe te kulture, ki jih ni mogoče natančno datirati, so pa lahko pokazatelji morebitnih stikov z območjem ljubljanske kulture. ${ }^{186}$ Proti zahodu je njeni širitvi mogoče slediti do slovenskega in Tržaškega Krasa ter morda tudi v severno Italijo, proti jugu pa do vzhodnih obal Jadranskega morja, kjer se tovrstna keramika pojavlja predvsem $\mathrm{v}$ jamskih najdiščih (karta 1$){ }^{187}$

183 Dimitrijević 1982, t. 8: 5.

184 Benac 1948, 16-17, tab. VI: 5; Benac 1961, t. 32: 4.

185 Ilon 1996, 7, t. 1; Kiss 2012, sl. 2: 3; glej tudi Leghissa, Bernardini, Kiss 2018.

186 Najdba z značilnim okrasom motiva ribje kosti iz Hrustovače v objavah M. Mandića (1939) in Josipa Korošca (1946) sploh ni omenjena. Prvič jo je objavil Alojz Benac leta 1948 . Ob omembi najdbe pa ni navedena natančna lokacija odkritja; izvirala naj bi iz iste plasti kot preostale najdbe, pripisane vučedolski kulturi, okras pa naj bi bil izveden s "točkićem". Najdbo razlaga kot dokaz vplivov/ stikov z območjem kulture zvončastih čaš (Benac 1948, 16-17, tab. VI: 5). Glede na opis oblike posode in objavljeno fotografijo je najdba podobna skodelam tipa Sk5 z Dežmanovih kolišč. Podobni se zdita tudi izvedba in motivika okrasa (glej npr. Leghissa 2017, 183-184, prim. zlasti t. 117: 8 - Korošec, Korošec 1969, t. 54: 2; 115: 3).

${ }^{187} \mathrm{Na}$ karti 1 so predstavljena le najznačilnejša najdišča s keramiko ljubljanske kulture (izbor je pri vsakem najdišču naveden v oklepaju, spremna lončenina ni navedena). Nazadnje je karto razprostranjenosti najdišč ljubljanske kulture oz. "ljubljansko-jadranskega stila" predstavil S. Forenbaher (2018a, sl. 4 in 2018b, sl. 105), v katero je vključil 80 najdišč z zelo in manj značilno lončenino za "ljubljansko-jadranski stil" ter zgolj podobno. Vključil je tudi najdišča, s katerih se le omenja tovrstna lončenina, ni pa objavljena. Po mojem mnenju pa je v njegovo karto vključenih kar nekaj najdišč, ki nimajo značilne lončenine ljubljanske kulture, kot jo definiram, zato jih tudi ne upoštevam. Najdbe $z$ nekaterih najdišč na vzhodnojadranski obali in v Istri, npr. Uvala Duga na otoku Sušac, Gudnja, Spila (Nakovana), Laganiši, so bližje cetinski kulturi, predvsem glede izvedbe okrasa.
Za najdišča ljubljanske kulture na tem območju se pogosto uporablja Dimitrijevićeva oznaka jadranska varianta ljubljanske kulture. ${ }^{188} \mathrm{Na}$ najdiščih slovenskega in Tržaškega Krasa, ki so geografsko bližja območju Ljubljanskega barja, najdemo primerljive oblike in načine krašenja keramičnih posod, zato bi jih bilo verjetno ustrezneje obravnavati v okviru ljubljanske kulture Ljubljanskega barja ${ }^{189}$ in ne v okviru srednje- in južnojadranske razprostranjenosti tega fenomena. ${ }^{190}$

Še vedno pa ostaja odprto vprašanje o kulturnem in kronološkem odnosu med ljubljansko kulturo in njeno "jadransko varianto". Po sicer problematičnih datacijah najdišč Odmut in Grapčeva špilja bi bila ta varianta starejša od barjanske ljubljanske kulture. A med obema območjema - na eni strani Ljubljansko barje, slovenski in Tržaški Kras ter Istra, na drugi pa srednjejadransko primorje - najdemo podobnosti in tudi očitne razlike. $\mathrm{V}$ prispevku omenjene razlike so lahko posledica stanja raziskanosti, načina raziskav ali konteksta odkritij, lahko pa so tudi kulturno in časovno pogojene. Vprašanje, na katerega bodo lahko ponudile odgovor le nadaljnje raziskave, pa je, ali je nastanek in predvsem razvoj jadranske variante ljubljanske kulture povezan $\mathrm{s}$ širjenjem vplivov ljubljanske kulture $\mathrm{z}$ območja Ljubljanskega barja ali pa je morda razvoj na obeh območjih potekal samostojno.

188 Dimitrijević 1967.

${ }^{189}$ V smislu Dimitrijevićeve alpske variante ljubljanske kulture.

${ }^{190}$ Podobno jih je obravnaval tudi Govedarica (1989). Med obema območjema, tj. Ljubljanskim barjem in Krasom, so očitne razlike predvsem $\mathrm{v}$ značaju najdišč - kolišča na Ljubljanskem barju, jame na Krasu.

Elena Leghissa

Znanstvenoraziskovalni center SAZU

Inštitut za arheologijo

Novi trg 2

SI-1000 Ljubljana

elena.leghissa@zrc-sazu.si 